\title{
The Judge in the Delivery Room: The Emergence of Court-Ordered Cesareans
}

\author{
Nancy K. Rhoden $\dagger$
}

It is common knowledge that im recent years doctors have begun recommending and performing far inore deliveries by Cesarean section than ever before. ${ }^{1}$ What is less well known is that in an increasing number of cases, courts are requiring woinen wlio resist this recommendation to "follow doctor's orders." Only one of these cases-Jefferson $v$. Griffin Spalding County Hospital Authority ${ }^{2}$-lias been officially reported. Another case has been described in the medical literature by the woman's physician and the hospital attorney. ${ }^{3}$ But many more cases are coinpletely unpublislied, ${ }^{4}$ depriving this issue of the public concern and scrutiny that it deserves.

New technologies for visualizing the fetus, detecting abnormalities, and possibly even correctimg them, along witl increasing knowledge of the detrimental fetal effects of various substances, are setting the stage for a host of potential inaternal/fetal conflicts. ${ }^{5}$ Because the Cesarean

$\dagger$ Associate Professor of Law, Ohio State University College of Law. B. A. 1974, Oberlin College; J.D. 1977 New York University School of Law.

I wish to thank John Arras, Nancy Dubler, Alan Fleischman, Angela Holder, Dawn Johnsen, Jay Katz, and Ruth Macklin for their helpful comments on an earlier draft of this Article. I also wish to thank the National Endowment for the Humanities and the National Science Foundation for research support, and Albert Einstein College of Medicine for the hospitality and access to medical information and personnel that it provided.

1. See infra text accompanying notes $43-44$ for a description of the rise in Cesarean section rates.

2. 247 Ga. 86,274 S.E.2d 457 (1981).

3. See Bowes \& Selgestad, Fetal Versus Maternal Rights: Medical and Legal Perspectives, 58 OBSTETRICS \& GYNECOLOGY 209, 211 (1981). The case described in this Article is In re Unborn Baby Kenner, No. 79 JN 83 (Colo. Juv. Ct. Mar. 6, 1979).

4. See, e.g., In re Baby Jeffries, No. 14004 (Jackson County, Mich. P. Ct. May 24, 1982) (order authorizing surgery); North Central Bronx Hospital v. Headley, No. 1992-85 (N.Y. Sup. Ct. Jan. 6, 1986) (order authorizing surgery). Some cases arise and are decided so quickly that no written order is issued. Interview with Judge Margaret Taylor, Family Court in New York City (Nov. 6, 1985) (describing 1982 case in which Judge Taylor refused to issue an order sought by attorneys for St. Vincent's Hospital) [hereinafter Taylor Interview].

5. There is a burgeoning literature on these potential conflicts, much of it analyzing the potential impact of in utero fetal therapy. See, e.g., Barclay, McCormick, Sidbury, Michejda \& Hodgen, The Ethics of In Utero Surgery, 246 J. AM. MED. Assoc. 1550 (1981); Fletcher, Healing Before Birth: An Ethical Dilemma, 87 TECH. REv. 27 (1984); Hubbard, Legal and Policy Implications of Recent Advances in Prenatal Diagnosis and Fetal Therapy, 2 WOMEN'S RTS. L. REP. 
dilemma is currently upon us, its resolution will be a crucial precedent for analyzing impending conflicts. But this dilemma is also extremely important, and extraordinarily difficult, in its own right. In a matter of hours or even minutes, a judge must decide whether to mandate major surgery for a competent, unconsentimg adult-a decision that is virtually unprecedented in American jurisprudence- or to uphold the woinan's refusal, with its potentially tragic consequences for her baby. This dilemma is generated by advances in medical technology that allow doctors to bestow upon the fetus the status of a patient. Its resolution is a part of the broader question of how society should respond to new medical technology.

Several areas of the law seem relevant to an analysis of this issue. The first is child neglect law and its fundamental principle that parents cannot deny life-saving medical care to their children. ${ }^{6}$ Soine courts and commentators have extended these principles to suggest that a pregnant woman cannot lawfully deny needed medical care-including a Cesarean section - to her unborn child. ${ }^{7}$ I argue, however, that child neglect law is of little relevance to the Cesarean conflict because of the enormous conceptual and practical gulf between ordering treatment for a child and compelling a woman to subnit to surgery for the benefit of a fetus, even where the fetus is on the threshold of independent life.

Instead, the proper way to analyze tlie Cesarean dilemma is as a special category of treatment refusals by competent patients. Thus, I discuss the general right to refuse treatment and tlose state interests that may weiglı against this riglit. The Cesarean conflict is unique in that the treatment is typically intended for the fetus's benefit, not the woman's. ${ }^{8}$ Hence "Samaritan law," that is, the law of rescue, is the most appropriate model for analysis. Exammation of it shows that in no other situation are rescues that risk life or limb mandated by law. I conclude, therefore, that women sliould not be compelled to undergo significant risks in order to save endangered fetuses. A brief look at courts' steadfast

201 (1982); Ruddick \& Wilcox, Operating on the Fetus, 12 THE HASTINGS CENTER REP. 10 (Oct. 1982). Part II.

6. For a discussion of this principle and its application to the Cesarean dilemma, see infra

7. See, e.g., Jefferson v. Griffin Spalding County Hosp. Auth., 247 Ga. 86, 88-89, 274 S.E.2d 457, 459-60 (1981); Myers, Abuse and Neglect of the Unborn: Can the State Intervene?, 23 DUQ. L. Rev. 1, 26-31 (1984); Robertson, The Right to Procreate and In Utero Fetal Therapy, 3 J. LEGaL MED. 333, 352-53, 357-59 (1982). The terms "fetus" and "unborn child" will be employed because in these situations birth is generally imminent, and the damage will accrue to the baby upon birth. This usage is not meant to suggest that there is no difference in status between the nine-month fetus in utero and the neonate ex utero. In these cases the important issue is not the presence or absence of fetal "personhood," however, but what types of intervention, if any, can be imposed on the woman for the fetus's benefit.

8. It should be noted that in some cases surgical delivery is needed for both the woman's and the fetus's sake. See infra text accompanying notes 54-55. 
refusal to order risky surgical interventions to promote other state interests will support this conclusion.

In addition, I argue that abortion law, properly interpreted, precludes nonconsensual surgery. Courts that order Cesareans often rely upon the holding in Roe v. Wade $e^{9}$ that a state's interest in potential hife becomes compelling at viability. ${ }^{10}$ However, Roe merely allows states to prohibit intentional fetal destruction after viability, unless abortion is needed to protect the woman's life or health. ${ }^{11}$ It says nothing about whether the state may require invasive medical procedures to promote fetal health. Moreover, Roe and subsequent Supreme Court abortion decisions consistently stress that the woman's health is primary; that is, even after fetal viability, states cannot require physicians to make "tradeoffs" between fetal and maternal well-being. ${ }^{12}$ Compnlsory Cesareans, I argue, are precisely the sort of trade-offs that cannot be compelled.

The conclusion that surgery should be optional is far from ideal. It has the profonndly disturbing implication that some preventable tragedies will occur; some babies who could have thrived will die or suffer devastating damage. One must therefore ask whether this conclusion is ethically supportable. It is. Even if a woman is thought to have a moral obligation to subinit to surgery to save her unborn child, no objective third party, not even a court, should presuine to perform the subjective and value-laden task of weighing surgical risks for the woinan. Moreover, although the consequences in an individual case will probably be far better if surgery is performed, the court that mandates surgery is treating the woinan solely as a means to the goal of saving the baby. When the judiciary acts in this consequentiahist manner it compromises its own integrity, because it can achieve good ouly by doing evil. It is far better that some tragic private wrongs transpire than that state-imposed coercion of preguant women become part of our legal landscape.

In Parts II through V, I assume for purposes of legal and ethical analysis that when physicians say a Cesarean is needed to save the fetus, they are indeed correct. In Part VI, however, I question the validity of that assumption in some cases. Part VI describes how factors such as technological limitations, medical uncertainty, and fear of legal hability lead physicians to act in a highly risk-averse manner, intervening even when the need for intervention is not entirely clear. This part also describes the critique of American obstetrics that charges that each inter-

9. 410 U.S. 113 (1973).

10. See, e.g., Jefferson v. Griffin Spalding County Hosp. Auth., 247 Ga. 86, 90, 274 S.E.2d 457, 460 (1981); North Cent. Bronx Hosp. v. Headley, No. 1992-85, slip op. at 5 (N.Y. Sup. Ct. Jan. 6, 1986).

11. 410 U.S. at $163-64$.

12. See infra text accompanying notes 222-35. 
vention may increase the need for further, and inore aggressive interventions. This critique, even if valid only in small part, is particularly significant in the context of court-ordered Cesareans because the extreme time constraints that characterize these cases will often mean that the woman will be unrepresented or only inarginally represented. Hence, if courts accept the invitation to weigh the consequences for woman and fetus they will have little choice but to rely upon the physicians' assessments of risk and benefits.

Finally, I will briefly discuss the broader societal concern that compulsory Cesareans are likely to spawn other compulsory interventions. One Cesarean case appointed the physician guardian ad litein for the fetus, with authority to consent to whatever diagnostic and therapeutic procedures were necessary for its protection. ${ }^{13}$ Another authorized police action to bring the woman to the hospital against her will. ${ }^{14}$ If inajor surgery can be compelled, additional "fetal protection" measures may seem mild in comparison. ${ }^{15}$ Consequently, there potentially are significant social costs if we jettison the consent requirement for obstetrical care.

I should stress that I reached the conclusion that courts should not compel Cesareans, whatever the consequences to the fetus, only after a great deal of agonizing. The dilemma is so difficult that it borders on the intractable. My position is certainly not ideal, although it is, I believe, the lesser of the two evils. Perhaps the most important lesson that close scrutiny of this area can teach us is that the law cannot right some wrongs without introducing new ones of a potentially more far-reaching and disturbing nature.

\section{I}

\section{The EMERgence of Maternal/Fetal Conflicts}

The birthing process has always harbored the spectre of tragic choices between mother and child. Before surgical dehvery was possible, the only way to save the inother in an obstructed labor was to destroy the

\footnotetext{
13. North Cent. Bronx Hosp., 1992-85 (N.Y. Sup. Ct. Jan. 6, 1986).

14. In re Baby Jeffries, No. 14004, slip op. at 9 (Jackson County, Mich. P. Ct. May 24, 1982).

15. Among the interventions that have already been required for pregnant women are blood transfusions, Raleigh Fitkin-Paul Morgan Memorial Hosp. v. Anderson, 42 N.J. 421, 201 A.2d 537 (1964), cert. denied, 377 U.S. 985 (1964), including one for a previable fetus, In re Jamaica Hosp., N.Y.L.J. 15, May 17, 1985 (Queens County, Sup. Ct., Special Term II); civil commitment of a pregnant schizophrenic woman to protect the fetus, see Soloff, Jewcll \& Roth, Civil Commitment and the Rights of the Unborn, 136 AM. J. Psych1ATRY 114 (1979); administration of insulin over the religious objections of a pregnant diabetic, In re Unborn Baby Wilson, No. 81-108 AV (Mich. Ct. App. Mar. 9, 1981), and compulsory drug testing for a pregnant addict. This last case, from Maryland, is described in Fletcher, supra note 5, at 34; see also N.Y. Times, Apr. 27, 1983, at 18, col. 5.
} 
fetus by disnemberment or craniotomy. ${ }^{16}$ Because the Roman Catholic Cliurcl forbade the use of these techniques, women were sometimes sacrificed to save the hives of their offspring. ${ }^{17}$ The mfant would be removed by Cesarean, which was either performed post-niortem or which itself resulted in the nother's death. ${ }^{18}$

In the nineteenth century, newly developed obstetrical techniques increased the available options and, lence, somewhat dimimished the need for a stark inaternal-fetal triage. For exaniple, if labor was obstructed, doctors could use forceps in an attenipt to remove the fetus without either destroying it or killing the mother. ${ }^{19}$ Use of "mid" or "higl"" forceps frequently, however, either damaged the fetus or caused lacerations and tears in the nother. ${ }^{20}$ Such tears often caused "childbed" or puerperal fever, which was a leading cause of maternal death in the nineteenth century. ${ }^{21}$ By the late nineteentli century, Cesarean delivery with maternal survival becanie a possibility, although the nortality rate remained extremely high. ${ }^{22}$ When doctors chose surgery over fetal destruction they thereby chose to place the nother at great risk.

By the beginning of the twentieth century, use of anestlesia, sterile technique, and miproved surgical methods nrade Cesarean delivery a reasonable, though still risky, response to obstructed labor. ${ }^{23}$ It remained relatively rare, however, and was performed only when the wonian's life or liealtl1 was at stake. In 1939, for instance, Cesarean delivery comprised only $2.4 \%$ of all deliveries in New York City. ${ }^{24}$ Plysicians focused their concern on the wonian because childbirth was still hazardous $^{25}$ and because doctors lacked effective techniques for detectimg

16. Craniotomy is the surgical perforation and compression of the cranium in order to reduce head size. STEDMAN's MEDical Dictionary IlluSTRATED 334 (24th ed. 1982).

17. National Institute of Health, U.S. Department of Health and Human Services, Pub. No. 82-2067, Cesarean ChILdbirth: Report of a Consensus Development Conference 51 (1981) [hereinafter Cesarean ChILdBIRTH].

18. Id. at $51-52$.

19. Id. at 51 .

20. B. Rothman, Giving Birth: Alternatives in Childbirth 53 (1982); W. Wertz \& D. WERTZ, LyiNG-IN: A HiSTORY OF CHILDBIRTH IN AMERICA 37 (1977).

21. W. WERTZ \& D. WERTZ, supra note 20, at 109-11.

22. Cesarean Child dirth, supra note 17, at 52. The Consensus Development Committee lists an approximately $75 \%$ maternal mortality rate, $i d$. at 51 , and refers to the observations of a late nineteenth century medical historian. "[A] pregnant woinan in labor had a 50 percent chance of survival post-cesarean if she performed her own surgery, or if gored by a bull, compared to a 10 percent reported survival rate if attended to by a New York surgeon." Id. at 52 (citing Harris, Remark on the Cesarean Operation, 11 AM. J. OBSTET. N.Y. 620-26 (1879) and Harris, Cattle-Horn Lacerations of the Abdomen and Uterus in Pregnant Women, 20 AM. J. OBSTET. N.Y. 673-85 (1887)).

23. Cesarean ChiLdBIRTH, supra note 17 , at 52.

24. Id. at 54 .

25. Maternal mortality was 582.1 per 100,000 live births in 1935 , as compared with 9.9 per 100,000 in 1978. Id. at 270 , Table 1. 
threats to fetal well-being during delivery. ${ }^{26}$ But by the 1960 's, as inaternal mortality from Cesarean section became rare, Cesarean delivery became a means to enhance fetal outcome. ${ }^{27}$

Today physicians possess a host of tools for diagnosing fetal conditions that may be alleviated by surgical delivery. For example, ultrasonography may reveal placenta previa, a condition in which the placenta blocks the birth canal and surgical delivery is necessary to protect both mother and fetus. ${ }^{28}$ It may also show intrauterine growth retardation, which in some cases may suggest an inadequate supply of nutrients to the fetus, and inay warrant surgical delivery for the fetus's sake. ${ }^{29}$ Ultrasonograpliy may also imdicate that the fetus is in breech position. In this case, Cesarean dehivery increasingly is chosen on the theory that it will prevent birth injuries. ${ }^{30}$

Cesareans are most commonly recommended for the sake of fetal health when the electronic fetal monitor indicates fetal distress. ${ }^{31}$ Electronic fetal monitoring (EFM), which came into use in the 1970's, continuously records fetal heart rate and uterine contractions in order to determine the fetal response to labor. ${ }^{32}$ Physicians compare changes in fetal heart rate to the intensity and duration of uterine contractions in order to identify ommous fetal heart patterns. ${ }^{33}$ EFM may be conducted

26. Doctors and midwives attending childbirth could, however, listen for abnormalities in the fetal heart rate. This practice (called auscultation), can reveal gross abnormalities in fetal heart rate. See Haverkamp, Orleans, Langendoefer, McFee, Murphy \& Thompson, A Controlled Trial of the Differential Effects of Intrapartum Fetal Monitoring, 134 AM. J. OBSTET. \& GYNECOL. 399, 400 (1979).

27. Cesarean ChildBiRTH, supra note 17 , at 59 .

28. Bleeding in the last trimester of pregnancy is the most common symptom of placenta previa. Ultrasonography is the most accurate form of diagnosis, however. See J. WiLLsON \& E. CARRINGTON, OBSTETrics \& GYNECOLOGY 352 (6th ed. 1979). Complete placenta previa is life threatening to both fetus and mother. The risk to the mother is uncontrollable hemorrhage. $E$. TAylor, Beck's Obstetrical Practice ANd Fetal Medicine 468 (10th ed. 1976).

29. Certain maternal conditions, such as hypertension or preeclampsia, a disease of pregnancy involving both hypertension and proteinuria (protein in the urine), can decrease placental supply to the fetus and cause intrauterine growth retardation and fetal distress. See S. CHERRY, R. Berkowitz \& N. Kase, Medical, Surgical, and Gynecological Complications of PREGNANCY 124-26 (1985); Interview with Dr. Joanna Shulman, Assistant Professor of Obstetrics and Gynecology, Albert Einstein College of Medicine (Jan. 24, 1986) [hereinafter Shulman Interview]. If preeclampsia progresses to its most severe form (called eclampsia or toxemia), it can cause convulsions that threaten the life of mother and fetus. S. CHERRY, R. BERKOWITZ \& N. KASE, supra, at 124-26.

30. In $1970,11.6 \%$ of breech infants were delivered by Cesarean; in 1978, the rate was $60.1 \%$. CESAREAN ChILDBIRTH, supra note 17, at 139 Table 2.

31. Interview with Dr. Robert Hayashi, Director of Obstetrics and Gynecology, Harbor Hospital, University of California, Los Angeles in Los Angeles (May 28, 1985).

32. Haverkamp \& Orleans, An Assessment of Electronic Fetal Monitoring, 7 WOMEN \& HEALTH 115, 116 (1982).

33. Id. at 118. Three aspects of the fetal heart rate are relevant: the base line rate, accelerations and decelerations (the periodic fluctuations in the fetal heart rate), and the beat-to-beat variability (the difference in the heart rate between any two beats). Id. 
externally, with transducers attached to the woman's abdomen, ${ }^{34}$ or internally, with catheters inserted into the woman's vagina and an electrode placed on the fetus's scalp. ${ }^{35}$

Uterine contractions predictably affect fetal heart rate. For instance, a norinal slowing, or deceleration, occurs more or less simultaneously with the development of the contraction. ${ }^{36}$ Certain abnormal changes may occur, however. These include late decelerations, in which the slowmg of the fetal heart rate begins after the peak intensity of the contraction and extends into the period between contractions, and loss of beatto-beat variability, in which the normal variation in fetal heart rate during labor diminishes or disappears entirely. ${ }^{37}$ Although these patterns often can be eliminated by changing the woman's position or giving her oxygen, ${ }^{38}$ if they persist they suggest fetal anoxia (loss of oxygen). Prolonged fetal anoxia can cause neurological damage and even death.

When an ominous pattern persists despite attempts to correct it, doctors may take a blood sample from the fetus's scalp to determine whether the acid level in the blood has decreased to a level that indicates a lack of oxygen. ${ }^{39}$ Fetal scalp sampling is a somewhat complex techmique that requires access to the fetus's head through the vagina. Because EFM has a high rate of false positives, as will be discussed in greater detail in Part VI, scalp sampling is considered necessary to reduce the over-diagnosis of fetal distress. ${ }^{40}$ Persistence of an ominous heart rate pattern, with anoxia confirmed by scalp sampling, is generally considered an indication for emergency Cesarean. ${ }^{41}$

Doctors are far less hesitant to recominend surgical delivery today than they have been im the past. The safety of Cesareans has improved

34. Id. at 116-17; L. Cibils, Electronic Fetal-Maternal Monitoring: ANTEPartUM, INTRAPARTUM 54-55 (1981). Proper placement of the transducer is crucial in order to detect fetal heart sounds accurately and to avoid internal and external sound interference. Id. at 55 . Movements of the mother, and sometimes of the fetus, may require repositioning of the transducers, although newer transducers have several pairs of transmitting crystals that may be arranged to allow for more movement without loss of quality in the detected signals. Haverkamp \& Orleans, supra note 32, at 117; L. ClBiLs, supra, at 55.

35. Haverkamp \& Orleans, supra note 32 , at 117 . If, due to position, the scalp cannot be reached the electrode may be placed on any other presenting part. L. CiBILs, supra note 34, at 59.

36. Banta \& Thacker, Assessing the Costs and Benefits of Electronic Fetal Monitoring, 34 OBSTET. \& GYNECOL. SURV. 627, 628 (1979).

37. Id.

38. Id. In addition, oxytocin administered to induce or speed labor may generate an ominous fetal heart pattern. Simply ceasing administration of oxytocin may eliminate the patteru. Id.

39. Haverkamp \& Orleans, supra note 32, at 119.

40. Id. This does not mean that it is always done, however. It has been noted that: "The technique is difficult, awkward, uncomfortable for women, and technically difficult even with considerable experience." Id.

41. Experts emphasize that the indication for surgery is not simply the presence of fetal distress, but rather the presence of nonremediable distress. CESAREAN CHILDBIRTH, supra note 17, at $391-92$. 
enormously in recent years, with mortality declining from $113.8 / 100,000$ operations in 1970 to $40.9 / 100,000$ in $1978 .{ }^{42}$ Cesarean delivery has gone from being a relatively rare event to being virtually routine. In particular, the 1970's saw a dramatic increase in the Cesarean section ratewhile Cesarean delivery accounted for $5.0 \%$ of all deliveries in 1970,43 it climbed to $16.5 \%$ in $1980 .{ }^{44}$ The increased focus on fetal well-being has, of course, contributed to this rise.

Despite its improved safety record, Cesarean section is inajor surgery and, as such, is associated with higher rates of maternal mortality and morbidity than vaginal delivery. ${ }^{45}$ Overall, the risk of death from a Cesarean is about four times that from vaginal delivery. ${ }^{46}$ Anesthesia, whether general, spinal, or epidural, presents certain risks. ${ }^{47}$ Institutions report up to one-third of Cesarean patients as having soine type of postoperative infections. ${ }^{48}$ For example, infections of the endometrium, urinary tract, or surgical wound are five to ten times more common after Cesarean delivery than after vaginal birth. ${ }^{49}$ Other maternal risks include trauma to nearby organs (e.g., uterus, bladder, bowel), pulmonary embolus, delayed wound healing, hernia, bowel obstruction, and hemorrhage. ${ }^{50}$ Complications may compromise future clildbearing, ${ }^{51}$ and Cesarean dehivery renders subsequent surgical deliveries far more likely. ${ }^{52}$

42. Id. at 255. Maternal mortality in general has decreased from $582.1 / 100,000$ in 1935 to 9.9/100,000 in 1978, id., and 7.9/100,000 in 1982. National Center for Health Statistics, Advance Report of Final Mortality Statistics, 1982, 33 MONTHLY Vital Statistics Rep. 6 (No. 9 \& Supp., Dec. 20, 1984).

43. Cesarean Childbirth, supra note 17 , at 6 .

44. Haverkamp \& Orleans, supra note 32, at 127.

45. Cesarean ChildBirth, supra note 17 , at 268.

46. Id. Because maternal mortality is generally believed to be underreported, death rates from both vaginal and surgical delivery may be higher than official figures indicate. Id.

47. Any of these types of anesthesia may be used in a Cesarean delivery, and each has its advantages and disadvantages. Id. at 284-86. A risk of general anesthesia is aspiration of gastric contents into the lungs, a complication that can be fatal. Id. at 286. Spinal anesthesia can cause inaternal hypotension, which also is occasionally fatal. Id. at 292. More commonly, spinal or epidural anesthesia causes severe postpartum headache because of the lumbar puncture.

48. Marieskind, Cesarean Section, 7 WoMEn \& HEALTH 179, 186 (1982).

49. Cesarean Childbirth, supra note 17 , at 260.

50. Id.; see Banta \& Thacker, supra note 36 , at 635 .

51. Cesarean Childbirth, supra note 17 , at 261 . The uterine scar may rupture in subsequent pregnancy or delivery. Id. at 266. For unexplained rcasons, Cesarean section increases by sixfold the risk of developing a placenta previa in a subsequent pregnancy. Cotton, Read, Paul \& Quilligan, The Conservative Aggressive Management of Placenta Previa, 137 AM. J. OBSTET. \& GYNECOL. 687, 694 (1980).

52. Until recently, U.S. physicians have favored an almost universal policy of repeat Cesarean surgery in subsequent pregnancies. Marieskind, supra note 48, at 188; CESAREAN ChILDBIRTH, supra note 17, at 366 . This practice is changing somewhat because of increasing criticism and the recommendation of the Consensus Development Committee that in appropriate cases women with prior Cesarean sections be allowed a trial of labor. Id. at 367. 
Today, surgery that is safe (as major surgery goes), but fraught with greater maternal risk than vaginal delivery, is frequently recommended to promote the interests of the fetus. The vast majority of women will accept significant risk, pain, and mconvemience to give their babies the best chance possible. One obstetrician who performs innovative fetal surgery stated that most of the women he sees "would cut off their heads to save their babies."53 But occasionally a woman refuses a recommended Cesarean. Most often, this decision is based not on maternal risk, but upon fundamental religious beliefs that preclude surgery. For example, in both Jefferson and In re Baby Jeffries, ${ }^{54}$ women refused surgery on religious grounds even though they were diagnosed as having placenta previa, a condition that makes vaginal delivery potentially fatal for the woman and fetus. Similarly, in North Central Bronx v. Headley, ${ }^{55} \mathrm{Mrs}$. Headley held religious beliefs that precluded surgical intervention, even though hypertension and preeclampsia led her physicians to feel that vaginal delivery might endanger her, her fetus, or both.

Some women, however, do refuse because they fear surgery. Francis Kenner, a Colorado woman featured im a medical journal case study, was told during labor that she needed a Cesarean because the fetal monitor indicated fetal distress. ${ }^{56}$ She refused surgery at least in part because of concerns for her own health-she was morbidly obese, a factor that mcreases surgical risk. ${ }^{57}$ Nevertheless, Kenner's refusal to submit to surgery was not honored. In the only case of which I am aware in which the court did not override the woman's refusal, Judge Margaret Taylor describes the refusal of surgery as based on the woman's fear for her own health, a behef in "natural childbirth," and an intuition that the delivery would turn out fine despite the doctors' dire predictions. ${ }^{58}$

Women refuse for a variety of reasons. It is wortl noting briefiy that in a number of these cases surgery was not performed, yet the dire consequences expected by physicians never materialized. In Judge Taylor's case, the woman's sense that things wonld be fine was right, even though the fetus's umbilical cord was wrapped around its neck, a clear and unambiguous mdication for an emergency Cesarean. ${ }^{59}$ In Jefferson and Jeffries, women with placenta previa ended up delivering

53. Statement of Dr. Mitchell Golbus, Professor of Obstetrics, Gynecology and Reproductive Science, and Director of Reproductive Genetics Unit, Univ. of Cal. Medical Center, San Francisco, made at Planned Parenthood Conference on Human Fertility Regulation: Technological Frontiers and Their Implications, in New York City (Dec. 14, 1984).

54. No. 14004 (Jackson County, Mich. P. Ct. May 24, 1982).

55. No. 1992-85 (Sup. Ct., Special Term, Bronx City, N.Y. Jan. 6, 1986).

56. Bowes \& Selgestad, supra note 3, at 209.

57. Id. at 211 .

58. Taylor Interview, supra note 4.

59. Id. This was the woman's tenth pregnancy, and as it turned out the delivery was much faster than the doctors expected. 
vaginally (in Mrs. Jeffries's case, after she went into hiding) ${ }^{60}$ although complete placenta previa is a clearcut indication for surgical delivery. In Headley, the woman whom physicians diagnosed as requiring a Cesarean never returned to the hospital and instead had a successful home delivery. ${ }^{61}$ Only in the case of Francis Kenner, where the fetal monitor showed fetal distress, was the surgery actually performed. From the perspective of enforcing a court order, fetal inonitor cases have the advantage that the woman is $\dot{n} 1$ the hospital and in labor. They have the concomitant disadvantage, however, of relying on a particularly probleniatic technology, so that diagnoses of fetal distress may be wrong or, at least, overly alarmist. ${ }^{62}$

For now, however, my discussion assumes that medical predictions of fetal daniage or demise if surgery is not performed are correct. The question, then, is whether the woman, whatever her reasons, has a right to refuse surgery even though the refusal holds dire consequences for the fetus.

\section{I}

\section{The Relevance of Child Neglect LaW}

Some commentators argne that existing child neglect law enipowers the state to order a woman to undergo surgery for the benefit of her fetus in certain circunistances. ${ }^{63}$ They reason that because failure to provide essential medical treatment to a child constitutes child neglect, refusal of treatmient necessary to protect the fetus's health niay be deemed fetal neglect. I will show that relying on the law of child neglect to divine an enforceable legal duty not to commit "fetal neglect" is inappropriate and grossly oversimplified, given the disparity between a parent's relation to a child and a pregnant woman's relation to a fetus.

Although parents have the right to raise their children according to the dictates of their own consciences, ${ }^{64}$ it is well established that parental rights do not include life-and-death authority over their children. ${ }^{65}$ Parents who refuse to provide inedical care to a child whose life is threatened are guilty of child neglect. The state may intervene and order

60. See Annas, Forced Cesareans: The Most Unkindest Cut of All, 12 Hastings Center Rep. 16 (June 1982) (describing outcome of Jefferson case). Mrs. Jeffries's vaginal delivery is reported in Detroit Free Press, June 16, 1982, at 3A, 7A.

61. Shulman Interview, supra note 29.

62. See infra Part VII.

63. See, e.g., Myers, supra note 7, at 26-31, 71; Robertson, supra note 7, at 352, 357-58.

64. See generally Quilloin v. Walcott, 434 U.S. 246, 255 (1978); Prince v. Massachusetts, 321 U.S. 158, 166 (1944); Pierce v. Society of Sisters, 268 U.S. 510, 535 (1925). These cases stand for the proposition that parental decisions regarding custody, care, and nurturing of children generally lie within "the private realm of family life which the state cannot enter." Prince, 321 U.S. at 166.

65. See Prince, 321 U.S. at $166-67$ (right to practice religion does not include liberty to expose child to communicable disease, ill health, or death). 
necessary treatment, ${ }^{66}$ and it may do so even if the parents' refusal rests upon their deeply held rehigious beliefs. For example, courts routinely order blood transfusions for children whose parents refuse to permit them on religious grounds. ${ }^{67}$ Although some courts will tip the balance in favor of parental autonomy if there is minimal medical support for the parents' preferred course of action, ${ }^{68}$ others will order standard medical treatment over and to the exclusion of parental preferences for alternative or unconventional therapies. ${ }^{69}$ If a child's condition is progressive and will significantly impair the child's physical or mental development, courts will require treatment even if the child's life is not imminently threatened. ${ }^{70}$ Moreover, Federal "Baby Doe" legislation has significantly reduced parental authority to reject aggressive medical treatment even for those children who will mevitably be disabled. ${ }^{71}$

66. Custody of a Minor, 375 Mass. 733, 753-55, 379 N.E.2d 1053, 1065-66 (1978). The court ordered chemotherapy for Chad Green, a child with leukemia whose parents had favored laetrile treatment.

67. A. Holder, Legai Issues in Pediatrics and Adolescent Medicine 102 (2d ed. 1985); see, e.g., State v. Perricone, 37 N.J. 463, 181 A.2d 751 (1962).

68. See, e.g., In re Hofbauer, 47 N.Y.2d 648, 656, 393 N.E.2d 1009, 1014 (1979) (upholding parental decision to treat child with Hodgkin's disease with laetrile and metabolic therapy rather than with standard chemotherapy where the alternative treatment was recommended by a physician and the treatment was not "totally rejected by all responsible medical authority").

69. See Custody of a Minor, 378 Mass. 732, 393 N.E.2d 836 (1979). In this case, the second judicial decision involving Chad Green, the Supreme Judicial Court of Massachusetts went so far as to hold that parents who were providing the child with chemotherapy could not also give him laetrile or large doses of vitamins. Chad's parents fled to Mexico with him, where he received laetrile and "metabolic therapy" and died at the age of three. See Note, Judicial Limitations on Parental Autonomy in the Medical Treatment of Minors, 59 NEB. L. REv. 1093, 1105 n.63 (1980).

70. For example, in In re Jensen, 54 Or. App. 1, 633 P.2d 1302 (1981), despite the parents' religious objections, the court ordered surgery for a 15-month-old child with hydrocephalus (accumulation of fluid in the brain) because her condition, if untreated, could cause major mental and physical disability. Id. at 6-8, 633 P.2d at 1305-06.

71. In the "Baby Doe" case, parents denied consent for life-saving surgery for a baby with Down's syndrome and a correctable esophageal defect. The Indiana state courts refused to intervene. In re Infant Doe, No. GU8204-004A (Cir. Ct. Ind. Apr. 12, 1982), writ of mandamus dismissed sub nom. State ex rel. Infant Doe v. Baker, No. 482 \$ 140 (Ind. Sup. Ct. May 27, 1982), cert. denied, 464 U.S. 961 (1983). The Department of Health and Human Services (D.H.H.S.) then issued a series of regulations requiring that handicapped newborns receive all medically beneficial treatments. Each regulation was invalidated by Federal courts. The final regulation, 49 Fed. Reg. 1,622 (1984), was invalidated in United States v. University Hosp., 729 F.2d 144, 157-61 (2d Cir. 1984) (holding that D.H.H.S. lacked statutory authority to promulgate this rule), and in American Hosp. Ass'n v. Heckler, 585 F. Supp. 541 (S.D.N.Y.), aff'd sub nom. Bowen v. American Hosp. Ass'n, 106 S. Ct. 2101 (1986) (Baby Doe regulations not authorized by $\S 504$ of the Rehabilitation Act of 1973 because (1) hospital cannot treat without parental consent and does nothing wrong by failing to do so; and (2) administrative record did not support contention that discriminatory withholding of treatment was taking place). Subsequently, compromise legislation provided that failure to provide life-sustaining medical treatment to a disabled infant is a form of child neglect, but recognized certain exccptions to the treatment requirement. Amendments to Child Abuse Prevention and Treatment Act, 42 U.S.C. \$ 5102(3) (Supp. III 1985). For further discussion of these legal developments, see Rhoden, Treatment Dilemmas for Imperiled Newborns: Why Quality of Life Counts, 58 S. CAL. L. REv. 1283 (1985). 
Some judicial decisions have expanded the doctrine that failure to provide needed medical treatment constitutes child neglect to suggest that a similar principle can apply to the child who is en ventre sa mere. For example, in Jefferson the Supreme Court of Georgia upheld the lower court's finding that the fetus was a deprived child within the meaning of the state juvenile code. ${ }^{72}$ Other Cesarean cases have also found the fetus to be a dependent and neglected child within the juvenile code. ${ }^{73}$ Further, in In re Baby $X,{ }^{74}$ a Michigan appellate court held that a newborn suffering narcotic withdrawal because of the mother's heroin addiction during pregnancy was properly considered a neglected child within the jurisdiction of the Michigan probate court. ${ }^{75}$ Along with these scattered and sketchily analyzed opinions, commentators argue in a more sustained fashion for an expansion of child neglect law to include inaternal treatment of an unborn child. ${ }^{76}$

It is beyond the scope of this Article to discuss whether there are any actions a pregnant woman might take that could properly be labeled fetal neglect or abuse. Nonetheless, when applied to the Cesarean issue, the concept has serious difficulties that are overlooked or minimized by its proponents. An initial problem is that legislatures, in enacting child abuse and neglect statutes, did not have fetuses in mind. ${ }^{77}$ Recognizing

72. Jefferson v. Griffin Spalding County Hosp. Auth., 247 Ga. 86, 88, 274 S.E.2d 457, 459 (1981).

73. Bowes \& Selgestad, supra note 3, at 210; In re Baby Jeffries, No. 14004, slip op. at 9 (Jackson County, Mich. P. Ct. May 24, 1982) (holding the fetus a child within provisions of juvenile code). Developments in the Jeffries case are described in a series of newspaper articles. See Detroit Free Press, May 29, 1982; Detroit Free Press, June 13, 1982; and Detroit Free Press, June 16, 1982. Because child neglect is the traditional rubric under which courts override parental rights to make decisions for their children, courts may not explicitly intend to create a new notion of prenatal neglect by relying on negleet statutes, but may instead merely cite these statutes to support their jurisdiction. Interestingly, a concurring Justice in Jefferson would have rejected the "child deprivation" rubric but would have ordered surgery under the alternative ground of the court's equitable jurisdiction. $247 \mathrm{Ga}$ at 92, 274 S.E.2d at 461-62 (Smith, J., concurriug).

74. 97 Mich. App. 111, 293 N.W.2d 736 (1980).

75. Id. at $115-16,293$ N.W.2d at 739. This case should not be heavily relied upon for support of the prenatal negleet concept; the mother's prenatal conduct was found only to suggest subsequent child neglect. In illustration, the court stated: "Since prior treatment of one child can support neglect allegations regarding another child, we believe that prenatal treatment can be considered probative of a child's neglect as well." Id. at 116, 293 N.W.2d at 739 (emphasis added). Of course, unless the court believes that heroin addiction alone renders a woman unfit to be a mother, this sort of "prenatal treatment" (i.e., the addiction) cannot be probative of anything except the fact of addiction.

76. See Myers, supra note 7, at 26-31, 52-54 (arguing that the notion of fetal abuse and neglect may apply to maternal heroin addiction, alcohol abuse, etc., as well as to some refusals of treatments beneficial to the fetus); see also Robertson, supra note 7, at 352 (same).

77. A typical child abuse statute reads: "No person, who is the parent, guardian, custodian, person having custody or control, or person in loco parentis of a child under eighteen years of age or a mentally or physically handicapped child under twenty-one years of age, shall create a substantial risk to the health or safety of the child, by violating a duty of care, protection, or support. . .." Ohio Rev. Code ANN. $§ 2919.22($ A) (Anderson Supp. 1985). 
this, a number of decisions have refused to consider fetuses as children in interpreting state statutes that did not expressly include them. For exainple, in In re Steven $S^{78}$ a California appellate court expressed strong disapproval of the trial court which had ordered the civil commitinent of a preguant woman in order to safeguard her fetus. The appellate court held that the fetus was not a "person" within the ineaning of the Cahfornia Welfare and Institutions Code. ${ }^{79}$ Likewise, in In re Dittrick Infant, ${ }^{80}$ the Michigan Court of Appeals refused to find the state juvenile code apphicable to the unborn. ${ }^{81}$ Even in Jefferson, a concurring justice noted the absence of legislative intent to include unborn children within the scope of the Georgia abuse and neglect statute. ${ }^{82}$

Although certainly valid, arguments that use legislative intent to attack the relevance of child neglect law seem narrow and legalistic. Social, legal, and technological developments frequently result in the creation of new rights and duties based upon constitutional or statutory interpretations never imagined by their original authors. ${ }^{83}$ Moreover, a child neglect statute simply could be ainended to provide that "children" includes viable unborn children or, for that matter, previable ones, so long as previability abortion is not prohibited. ${ }^{84}$ The real question is whether child neglect law should be extended in this manner. Resolution of this issue will not be decisive because courts need not employ the fetal

78. 126 Cal. App. 3d 23, 178 Cal. Rptr. 525 (1981).

79. Id. at 28-30, 178 Cal. Rptr. at 527-28. The appeal was dismissed as moot because of the intervening birth of the child. Id. at 31-32, $178 \mathrm{Cal}$. Rptr. at 529. One provision of the California Penal Code $(\S 270)$ making it a misdemeanor for a parent willfully to faii to provide for a child explicitly includes unborn children. This statute, however, was historically intended to be directed at fathers who did not pay child support, or support during pregnancy, and was never meant to impose additional burdens on pregnant women. People v. Stewart, No. M50819, slip op. at 7-8, 10 (San Diego County, Cal. Feb. 26, 1987) (dismissing prosecution under this statute against Pamela Rae Stewart for conduct during pregnancy that allegedly caused her baby's death). For more bakground and legislative history of this statute, see Brief for Defendant at 13-24, id. (Feb. 23, 1987).

California courts have consistently held that when a statute does not specifically include the unborn, fetuses are not covered. See, e.g., Reyes v. Superior Court, $75 \mathrm{Cal}$. App. 3d 214, $141 \mathrm{Cal}$. Rptr. 912 (1977) (fetus not within protection of felony child endangering statute); Justus v. Atchison, 19 Cal. 3d 564, 579, 565 P.2d 122, 132, 139 Cal. Rptr. 97, 107 (1977) (legislature impliedly excludes fetuses when speaking generally of a "person" in a wrongful death statute).

80. 80 Mich. App. 219, 263 N.W.2d 37 (1977).

81. Id. at 223,263 N.W.2d at 39.

82. Jefferson v. Griffin Spalding County Hosp. Auth., 247 Ga. 86, 92, 274 S.E.2d 457, 461-62 (1981) (Smith, J., concurring). See supra note 73.

83. The abortion right is one salient example of this.

84. Certain state statutes concerning care and custody of children explicitly apply to the unborn. See Cal. Penal Code § 270 (West 1970 \& Supp. 1986); N.J. Stat. AnN. § 30:4C-11 (West 1981). Although any order concerning maternal conduct before viability could be avoided by aborting, John Robertson's point that when the woman definitely intends birth rather than abortion, there is no reason to limit her legal duties to after viability, secms correct. See Robertson, supra note 7 , at 361 . 
neglect concept to mandate a Cesarean for the fetus's sake. ${ }^{85}$ Nonetheless, its resolution is important because this concept allows its proponents to endorse an expansive acceptance of interventions into pregnant women's lives-imcluding major surgery. ${ }^{86}$

In expanding the concept of child neglect to include fetal neglect, advocates reason that: (1) children are harmed if denied medical care; (2) parents liave a legal duty to provide children witl needed care; (3) breacli of sucl duty constitutes child neglect; (4) forgoing certain medical procedures can be liarmful to fetuses; (6) therefore, forgoing such procedures constitutes fetal neglect. I lave labelled the conclusion " 6 " ratlier thin " 5 " because step 5 is imissing. This is the necessary premise that the law should impose positive legal duties upon women toward their fetuses just as it imposes duties upon parents toward their children. The law, lowever, lias never imposed sucl duties upon pregnant women. To impose them now is a ratlier significant feat of judicial legislation, and one whose novelty is obscured by too readily conflating children and fetuses. In fact, whether sucli duties should be created is the crucial question liere. Thus, the above argument is persuasive only if proponents can show why the law sliould now treat fetuses, which are still inside a woman's body, im the same way it treats children, who are physically separate from their parents.

Some proponents suggest that new medical techniques that make evaluation and treatment of the fetus more accessible are themselves reasons for extending cliild neglect statutes to the unborn. ${ }^{87}$ This argument is, lowever, patently untenable. Certainly, before there were evident fetal indications for Cesarean delivery or medical treatments for certain fetal syndromes, the issue of mandating procedures for the sake of the fetus could not arise. But the mere capability of domg an act ouly makes it possible-it does not make it necessary. Conduct must be justified by reasons extrimsic to the existence of inherently neutral means. Inasmuch

85. See infra text accompanying notes $130-36$.

86. For example, Myers suggests that acceptable types of nonconsensual intervention include Cesareans and in utero shunting of a hydrocephalic fetus. Myers, supra note 7, at 72-75. Presumably, Myers would mandate the latter procedure only if it ever became medically established. Currently, the results have been so discouraging (severe retardation in many survivors) that researchers have declared a self-imposed moratorium on the procedure. M. Golbus, Fetal Diagnosis and Therapy 28 (Paper presented to Planned Parenthood Federation of America, Symposium on Human Fertility Regulation: Technological Frontiers and Their Implications (Dec. 14, 1984)). Robertson lists a host of potential interventions, including prohibiting alcohol or drug use during pregnancy; requiring medication of women with diabetes or other diseases; requiring blood transfusious, prenatal screening, amniocentesis, and in utero fetal surgery; and even extra-uterine fetal surgery if it became an established procedure. Robertson, supra note 7, at 358-59; see also Shaw, Conditional Prospective Rights of the Fetus, 5 J. LEGAL MED. 63, 96-100 (1984) (suggesting mandatory reporting of fetal abuse, compulsory alcohol and drug abuse programs for pregnant women, and even compulsory abortion for the severely defective fetus).

87. Myers, supra note 7 , at 30-31. 
as the mere existence of technology cannot, by itself, warrant its use, ${ }^{88}$ it certainly can not justify such technology's compulsory use. ${ }^{89}$

Support for the nissing premise that women have legal duties to fetuses has also been sought in abortion law. In Roe v. Wade, ${ }^{90}$ the Supreme Court held that after viability a state's interest in potential life becoines coinpelling and that, pursuant to this interest, the state can prohibit abortions, "except when it is necessary to preserve the life or health of the mother." "91 In Jefferson, the court relied heavily upon the state's coinpelling interest in protecting a viable fetus in authorizing Cesarean dehvery. ${ }^{92}$ Similarly, a proponent of the prenatal neglect concept concluded:

The state's interest in viable fetal life permits it to forbid abortion, an act designed to extinguish life. It follows froin this that the state is empowered to proscribe other acts calculated or likely to lead to the same result. Furthermore, since the interest in preservation of fetal life authorizes intervention to prevent destructive acts, it should also authorize hinited coinpulsion of action which is necessary to preserve fetal life. Since a failure to act can as surely lead to frustration of the state's interest as an affirmative act, the underlying interest inust reach both cases. ${ }^{93}$

Although the abortion decisions will be discussed inore fully in Part IV, it is important to note here that abortion law yields no such conclusion. Prohibiting intentional destruction of a viable fetus differs significantly from inandating major surgery in order to save it. ${ }^{94}$ The fact that a state can constitutionally do the former simply does not tell us whether or not it can do the latter. ${ }^{95}$ In other spheres, it is clear that state interests justify only some types of actions to promote the interests. For exainple, the state interests in public health and morals inay justify state

88. To think so is to succumb to the "technological imperative," the notion that if something can be done, it must be done.

89. Use of technologies has been noted to tend to pass through stages from optional to mandatory. See D. Callahan, The TyranNy of Survival 256-57 (1973). As an example, Callahan discusses the dangers of genetic control technology passing from optional to compulsory use. Id. at 215-44. While this fortunately has not yet occurred, writers such as Dr. Margery Shaw, who favor numerous obstetrical interventions, advocate nonconsenual prenatal diagnosis and abortion for fetuses with particularly severe defects. Shaw, supra note 86, at 99-100.

90. 410 U.S. 113 (1973).

91. Id. at 163-64.

92. $247 \mathrm{Ga}$. at $87,89,274$ S.E.2d at 458,460 .

93. Myers, supra note 7, at 18 (footnotes omitted).

94. As two philosophers have put this, "While a liberty right to life might protect fetuses (if fetuses have this or any right) against abortion, it would not commit parents or surgeons to lifesaving surgery." Ruddick \& Wilcox, supra note 5 , at 11.

95. See Note, Jefferson v. Griffin Spaulding County Hospital Authority: Court-Ordered Surgery to Protect the Life of an Unborn Child, 9 AM. J.L. \& MED. 83, 88 (1983) (Roe balances a woman's privacy interests with the state's interest in preserving the viable fetus, but because Roe is concerned only with abortion, it cannot be read to subordinate all of a woman's privacy interests to the state's interest in the viable fetus). 
prohibition of the sale and use of narcotic drugs, but these interests do not thereby justify all measures that may prevent drug use, such as random stomach searches or preventive detention of suspected users. Similarly, the state's ability to restrict a woman's freedom to have an abortion does not, as a corollary, allow the state to deny her right to be free from physical intrusion. Affirmative duties to fetuses, thus, simply cannot be derived from the constitutionality of state prohibition of postviability elective abortions. ${ }^{96}$

Proponents of the fetal neglect concept also have suggested that because third parties may be held liable in tort for wrongfully killing or mjuring a fetus, ${ }^{97}$ pregnant women should likewise be liable for prenatal harm and, as a corollary, the state should be empowered to prevent such harn. ${ }^{98}$ This argument is flawed in a number of respects. First, the fact that tort or criminal hability may be imposed on completed conduct does not mean that any steps, no matter how extreme, are perinissible to prevent such conduct, especially when individuals' constitutional rights are implicated. For example, persons may sue for libel even though they may not obtam prior restraints against the libelous speech. ${ }^{99}$ Similarly, our society does not imprison people simply because they are likely to commit a crime, ${ }^{100}$ even though they can unquestionably be punished afterward. Thus even were women liable in tort for prenatally caused haruns (which they currently are not), ${ }^{101}$ this would not entail that the

96. This argument does not dispute the very persuasive claim that prohibiting abortion imposes an often unjustifiable affirmative duty on women to go through the rigors of pregnancy and birth. See Regan, Rewriting Roe v. Wade, 77 Mich. L. Rev. 1569, 1569-71 (1979); Thomson, $A$ Defense of Abortion, 1 PHIL. \& PuB. AFF. 47, 48-52 (1971). Proponents of this position usually agree that at some point fairly late in pregnancy the state can legitimately prohibit abortion, even though this still imposes the duty on the woman to go through the rest of the pregnancy and delivery. But whether or not one accepts Thomson's and Regan's view of state restrictions on abortion, requiring a woman to submit to major surgery unquestionably imposes an affirmative duty upon her-a duty whose permissibility does not follow from the mere fact that after some point in pregnancy, abortion may legitimately be proscribed.

97. See RESTATEMENT (SECOND) OF TORTS $\$ 869(1)$ (1977) (liability for prenatal injury if child alive); Kader, The Law of Tortious Prenatal Death Since Roe v. Wade, 45 Mo. L. REv. 639, 642-45 (1980) (listing states allowing recovery for wrongful death of stillborn).

98. Myers, supra note 7, at 30-31; Robertson, supra note 7, at 352-55, 357-61.

99. In general, speech can be subjected to prior restraints only when it constitutes a clear and present danger to the public. See generally W. LAFAve \& A. ScotT, HandBook ON CRIMINAL LAW 157 (1972); Redish, The Proper Role of the Prior Restraint Doctrine in First Amendment Theory, 70 VA. L. REV. 53 (1984).

100. See, e.g., Williamson v. United States, 184 F.2d 280, 282 (2d Cir. 1950) (imprisonment because of "anticipated but uncommited crimes" violates American legal traditions); W. LAFAVE \& A. ScoTT, supra note 99, at 503 (bad thoughts alone cannot constitute a crime). Of course, the state can make criminal acts preparatory to a crime-the crime of attempt, id. at 423-35; or an agreement among persons to commit a crime-the crime of conspiracy, id. at 453-95.

101. According to Beal, "Can I Sue Mommy?" An Analysis of a Woman's Tort Liability for Prenatal Injuries to Her Child Born Alive, 21 SAN DIEgo L. Rev. 325, 326 n.8 (1984), no state court of last resort has ever held a woman liable in tort for injuries to her child caused by her prenatal 
state could prospectively restrict their conduct to prevent such harms.

Additionally, the pregnant woman stands in a different relationship to the fetus than does a third-party tortfeasor. Third parties who tortiously injure a woman and her fetus act without justification. Innosing liability on tortfeasors may be viewed as compensating the child, once it is born, for prenatal injuries or, in the case of fetal death, compensating the parents for loss of their child. ${ }^{102}$ But pregnant women have a constitutional right to abort a fetus for a substantial portion of pregnancy-a right that would be inconsistent with third-party hability for death of a previable fetus were one to fail to recognize the importance of the woman's unique status. Unlike a third-party tortfeasor, a pregnant woman has fundainental rights of privacy and bodily integrity that justify her choice of abortion, or at least render state interference problematic. ${ }^{103}$ Thus, the mere fact of third-party tort hability cannot justify the subjection of woinen to invasions of their constitutional rights in order to prevent prenatal harms. ${ }^{104}$

Yet another argument for imposing a legal duty upon women to undergo surgery for the benefit of their fetuses suggests that because parents inust be good proxy decisionmakers for their children, so too women, as proxy decisionmakers for fetuses, inust make good medical decisions for thein. Along these lines, one scholar argues that if a father were denying medical care to his child and also blocking access to himlike George Wallace standing in the schoolhouse door-one would be justified in pushing the father aside to treat the child. ${ }^{105}$ The problem

conduct. One intermediate appellate court, however, allowed a child to include his mother as a defendant in a suit seeking recovery for discolored teeth, allegedly caused by the mother's use of tetracycline during pregnancy. Grodin v. Grodin, 102 Mich. App. 396, 301 N.W.2d 869 (1980). Beal supports this extension of tort liability, but without fully recognizing the constitutional problems inherent im a state-imposed duty to act in the best interest of the fetus. Beal also suggests that tort suits would be brought only when insurance was available. Id. at 358, 369. This ignores the potential for suits, whether or not there is insurance, when parents of a handicapped child are involved in an acrimonious divorce.

102. See Gallagher, The Fetus and the Law-Whose Life Is It Anyway?, Ms. MAGazine, Sept. 1984, at 62, 135; Note, The Creation of Fetal Rights: Conflicts with Women's Constitutional Rights to Liberty, Privacy, and Equal Protection, 95 YALE L.J. 599, 600-04 (1986).

103. In explaining why allowing recovery for wrongful death of a fetus is not inconsistent with the abortion right, one writer states, "The perception of inconsistency may, however, result from an overemphasis on equating the status of the objects of an action, and insufficient emphasis on distinguishing the actors involved. The inconsistency inay thus be justified, if not erased, by recognition of the different interests of the actors involved." Kader, supra note 97, at 659.

104. In cases in which the potential harm will be caused by the woman's failure to agree to a medical procedure (as opposed to, say, cases in which the harm will be caused by her use of heroin or alcohol), she may be viewed simply as refusing to rescue the fetus, a refusal that is consistent with the absence of any duty to undertake risky rescues in general. See infra Part III.

105. Presentation by Dr. Norman Fost, Hastings Center Conference on Abortion and Scientific Change at Hastings-on-Hudson, New York (May 24, 1985) (discussing ethical issues in fetal treatment). 
with viewing pregnant women as proxies and/or barriers to access is that the medical treatment involves their bodies too, and in a far more intrusive inanner than merely pushing thein aside. In other words, it is the need for invasive bodily intrusion upon the woman that makes these inaternal-fetal conflicts unique. A more accurate analogy would be if the recalcitrant father were very obese and securely wedged in the door, and gaining access to the sick child to provide treatment required cutting through the father. Such a dilemma would be inuch harder, and any decision would have to consider the impact on both parties.

Ultinately, equating the woinan's refusal of a Cesarean to fetal neglect is improper because it focuses entirely upon the fetus and ignores the fact that a surgical intrusion upon the woman's body is also at issue. This approach is tantamount to defining a father's suicidc as child abandonment ${ }^{106}$ or parents' move to a distinct locale as "child displacement." Even if a court orders surgery, it cannot forget the woinan is there-and there in a more substantial role than either a mere fetal proxy or an inconvenient, albeit necessary, fetal container. ${ }^{107}$ Legal duties should not be imposed without serious consideration of the burdens on her, and the child neglect rubric oimits such consideration. Because there are no correlative physical burdens involved in providing inedical treatment for one's child, child neglect law is far less relevant than it initially appears. Moreover, the "fetal neglect" rubric approaches this issue froin the wrong direction in that it first asks what course of action is best for the fetus and then forces the woman to justify taking a contrary course. This is wrong because whenever nonconsensual physical invasion is involved, the burden inust be on the state to justify overriding a competent refusal of treatinent. Discarding the fetal neglect concept does not itself mean that the state could never meet this burden, because the state has a legitimate interest in protecting potential life. Discarding it does, however, launch our inquiry froin the proper direction.

\section{III}

\section{Refusal of Treatment NeEded to BeNEFit ANOtheR}

A inore appropriate framework for analyzing the Cesarean conflict draws both on doctrine granting conıpetent adults the right to refuse

106. Another analogy might be to characterize rules that prevent pregnant women from working near toxic substances as nothing more than "fetal protection" rules. While the question of when and whether such prohibitions are proper is a hard one, analysis must include discussion of pregnancy discrimination and sex discrimination as well as fetal protection. See generally Williams, Firing the Woman to Protect the Fetus: The Reconciliation of Fetal Protection with Employment Opportunity Goals under Title VII, 69 GEO. L.J. 641 (1981).

107. Some of Dr. Margery Shaw's argnments have overtones of the container theory, for example, her suggestion that breathalyzer tests of pregnant women would probably be constitutional because the women would be furnishing alcohol to a minor. Shaw, supra note 86, at 103 . 
medical treatment and on the law of rescue. Refusal of a Cesarean is unique among medical treatment refusals because, typically, the treatment is needed to save the fetus and not the woman. In other words, the fetus is in need of rescue, and this rescue can be accomplished only if the woman submits to surgery. The unique nature of pregnancy also means that no other type of rescue will be precisely analogous to the Cesarean dilemma. While recognizing the limitations of any analogy, still, the most pertinent legal doctrines involve treatment refusals and the duty to rescue imperiled persons with whom one has a special relationship. Consideration of these two areas, along with a brief look at other spheres in which the issue of state-imposed bodily mvasion arises, will show that to compel major surgery for the fetus's sake is an imposition unparalleled in American law, and unjustified according to equal protection doctrine. ${ }^{108}$

\section{A. The Right to Refuse Treatment}

Medical treatment requires the consent of the patient. A well-established precept of American law is that without consent even a successful medical procedure constitutes battery. ${ }^{109}$ Consent is required because "[e]very human being of adult years and sound mind has a riglit to determine what shall be done with his own body . ..."110 Early cases asserted the common law right to bodily integrity agamst physicians who either failed to obtain consent or exceeded the agreed-upon scope of the operation. ${ }^{11}$ More recently, lowever, patients have claimed that even though consent was obtained it was invalid because it was not fully inforined. ${ }^{12}$ In upholding these claims, courts have fashioned the doctrine of inforined consent to impose liability in negligence, rather than battery, upon doctors who fail to give the information necessary for the patient to make a free and fully imforned decision. ${ }^{113}$ This doctrine relies on the

108. For another analysis taking this same approach to maternal-fetal conflicts and reaching the same conclusion as reached herein, see Nelson, Buggy \& Weil, Forced Medical Treatment of Pregnant Women: "Compelling Each to Live as Seems Good to the Rest", 37 Hastings L.J. 703, 753-62 (1986). This excellent piece deserves more extensive commentary and analysis than can be provided here, since it came out as this Article went to press.

109. Schloendorff v. Society of N.Y. Hosps., 211 N.Y. 125, 129-30, 105 N.E. 92,93 (1914).

110. Id. at 127, 105 N.E. at 93.

111. See id. See generally Annotation, Liability of Physician or Surgeon for Extending Operation or Treatment Beyond that Expressly Authorized, 56 A.L.R. 2d 695, 709-16 (1957) (describing cases in which doctors were held liable for assault and battery for performing major or radical surgery, when patient consented only to minor surgery).

112. See, e.g., Cobb v. Grant, 8 Cal. 3d 229, 502 P. 2d 1, 104 Cal. Rptr. 505 (1972): Natanson v. Kline, 186 Kan. 393, 350 P.2d 1093, clarified, 187 Kan. 186, 354 P.2d 670 (1960).

113. See e.g., Cobbs v. Grant, 8 Cal. 3d at 239-41, 502 P.2d at 7-8, 104 Cal. Rptr. at 511-12. The risk of failing to inform the patient must have materialized, that is, the patient must show that he (or, more commonly, a hypothetical reasonable person) would have decided differently had he been adequately informed. See Canterbury v. Spence, 150 U.S. App. D.C. 263, 281-82, 464 F.2d 772, 790-91 (reasonable person standard), cert. denied, 409 U.S. 1064 (1972); Scott v. Bradford, 606 
theory that the rights to autonomy and bodily integrity are violated if facts necessary for an informed choice are withheld. The possibility of serious harm, such as death or paralysis, must be disclosed even if the harm rarely occurs. For example, in one of the seminal informed consent cases, Canterbury v. Spence, ${ }^{114}$ a young inan underwent surgery to correct a ruptured disc and becaine paralyzed from the waist down. He alleged that he should have been told of the approximately one-percent risk of paralysis. The court held that the physician owed a duty to disclose the dangers of proposed treatment, and that the trial court erred in directing a verdict for the defendant physician. ${ }^{115}$

The informed consent doctrine illustrates two salient features of American law. First, it shows the extent to which patient autonomy is respected ${ }^{116}$ and highlights how nonconsensual surgery deviates sharply from our society's respect for such autonomy. Second, it shows that riskbenefit judgments about medical treatment are the patient's to make, and not the doctor's. A physician may consider it absurd to forego potentially beneficial surgery because of a one-percent risk of paralysis. But individuals weigh risks differently, and the informed consent doctrine respects this. ${ }^{17}$ The doctrine therefore suggests that those who would override a patient's informed choice should bear a very heavy burden of proving that overriding a patient's coinpetent choice is, under the circumstances, warranted.

The informed consent requirement would be meaningless if patients had no choice but to obey doctors' orders. They do have a choice, how-

P.2d 554, 558-59 (Okla. 1979) (subjective standard). These requirements are criticized by some experts as a retreat from the doctrine's foundation in the right of individual autonomy. See J. KATZ, THE Silent WORLD OF DOCTOR AND PATIENT 71-84 (1984).

114. 150 U. S. App. D.C. 263, 464 F.2d 772, cert. denied, 409 U.S. 1064 (1972).

115. 464 F.2d at 779, 794. The applicable legal standard for what information must be disclosed is much disputed. Many jurisdictions take the physician's perspective, asking what information a reasonable practitioner would disclose under the circumstances. See, e.g., Karp v. Cooley, 492 F.2d 408 (5th Cir.), cert. denied, 419 U.S. 845 (1974); Buckner v. Allergan Pharmaceuticals, Inc., 400 So. 2d 820 (Fla. Dist. Ct. App. 1981); Marchlewicz v. Stanton, 50 Mich. App. 344, 213 N.W.2d 317 (1973). Others require that the physician provide all information that a reasonable person in the patient's position would find significant in reaching a decision. Canterbury, 464 F.2d at 786-87; Cobbs, 8 Cal. 3d at 245, 104 Cal. Rptr. at 515-16, 502 P.2d at 11-12; Wilkinson v. Vesey, 110 R.I. $606,627-28,295$ A.2d 676, 689 (1972). The patient-oriented standard has the problem that doctors may not know what a reasonable patient would find material. See C. LiDz, A. Meisel, E. Zerubavel, M. CARTer, R. Sestak \& L. Roth, Informed Consent: A Study of Decisionmaking IN PSYchiatry 14 (1984). But many commentators prefer this standard because it more faithfully promotes the values of individual privacy and autonomy that underlie the informed consent doctrine. See, e.g., D. MEYERS, MEDICO-LEGAL IMPLICATIONS OF DEATH AND Dy1NG 81-82 (1981); C. LIDZ, supra, at 14.

116. I am mindful, of course, of the extent to which the doctrine has failed to livc up to its promise, both in its legal development and in its impact on physician-patient decisionmaking. For a most telling critique, see generally, J. KATZ, supra note 113 .

117. Of course, complete deference to patients' subjective risk assessment is limited in most jurisdictions by the reasonableness of physicians' nondisclosure. 
ever, that is founded on the increasingly accepted corollary to informed consent: competent imdividuals can refuse medical treatment even if this will result in their death. ${ }^{118}$ The right to refuse treatment is supported by the common law right to bodily integrity and is encompassed within the constitutional right to privacy. ${ }^{119}$ The right is fundamental and its scope broad. For example, refusals have been upheld even when the patient was mentally ill (though not legally incompetent) and her reasons were highly unusual. ${ }^{120}$ Refusal of treatment has also been honored when such treatment could return a young patient to a vibrant and healthy life. $^{121}$

Although the right to refuse treatment has become increasimgly well established, courts nonetheless note that it is subject to countervailing state interests. These are: (1) the preservation of life; (2) the protection of dependent third parties; (3) the prevention of suicide; and (4) the preservation of the ethical integrity of the medical profession. ${ }^{122}$ The crucial question is how much weight must be given to the relevant state interests. In inost Cesarean cases, the woman's life will not be threatened by vaginal delivery, making the interest in suicide prevention irrelevant. Even if her hife is in danger as well-if she has placenta previa, for example-it is increasmgly accepted that treatment refusal is not the same thing as suicide, even if it results in death. ${ }^{123}$ Thus, the interest in preventing suicide will not be considered. Each of the other state interests is relevant and will be discussed in turn.

The interest in the ethical integrity of the medical profession is seldom strongly implicated in treatment-refusal cases because, although refusals may be emotionally very difficult to honor, medical ethics do not

118. See, e.g., Lane v. Candura, 6 Mass. App. Ct. 377, 376 N.E.2d 1232 (1978) (holding that irrationality of patient's refusal of amputation does not justify conclusion of incompetence and surgery cannot be done against patient's will); In re Quackenbush, 156 N.J. Super. 282, 383 A.2d 785 (1978) (ruling that competent patient with gangrene may refuse recommended leg amputation even though refusal will result in death); In re Melideo, 88 Misc. 2d 974, 390 N.Y.S.2d 523 (Sup. Ct. 1976) (Jehovah's Witness's refusal of blood transfusion upheld even though possibly necessary to save her life).

119. See Superintendent of Belchertown State School v. Saikewicz, 373 Mass. 728, 370 N.E.2d 417 (1977) (incompetent patient's constitutional right of privacy may be asserted by guardian refusing life-support treatment for incompetent person); In re Quinlan, 70 N.J. 10, 355 A.2d 647 (1970) (same).

120. See In re Yetter, 62 Pa. D. \& C.2d 619 (1973) (refusal of breast biopsy upheld even though 60-year-old patient's reasons included not only her fear of death but her clearly delusional fear of loss of child-bearing capacity and chance for a movie career).

121. See, e.g., Matter of Osborne, 294 A.2d 372 (D.C. 1972); In re Melideo, 88 Misc. 2d 974, 390 N.Y.S.2d 523 (Sup. Ct. 1976).

122. Saikewicz, 373 Mass. at 741,370 N.E.2d at 425 .

123. The primary reason for this is that in refusing treatment, the patient does not actively kill himself, but merely exercises his right to privacy. This is the ease even if death ensues, because it will have been caused not by an affirmative act of the patient, but by a natural disease process. See D. MEYERS, supra note 115 , at 249. 
require imposing treatment upon unwilling persons. ${ }^{124}$ In obstetrical cases, however, doctors today tend to feel that they are caring for two patients-the mother and the fetus-to whom they have independent obligations. It could be argued that in these cases the state interest in the integrity of the medical profession supports compulsory treatinent. Yet, this state interest is insufficient to warrant compulsory treatinent for two reasons. First, there is no unanimity within the medical community with respect to these conflicting or dual obligations. Many physicians believe that a pregnant woman's competent refusal should be respected. ${ }^{125}$ This diversity of opimion within the medical community undermines the arguinent that professional integrity supports coinpulsory treatment. Second, even if physicians were unanimous in feeling that their obligations to the fetus justified compulsory treatment for the woman, this is too important and complex a societal issue to be decided on the basis of doctors' views of their professional obligations. As discussed earlier, doctors have no duty, and in fact have no right, to perform procedures without consent; doing so constitutes battery. Whatever their views, they cannot lawfully proceed in the face of refusal without a court order. Any judicial determination of the conflicting rights and interests at stake inust therefore take into account much inore than the doctors' vision of their obligations. If courts empower doctors to act as state agents in performing nonconsensual surgery, courts should do this not because of professional inedical obligations and judgments, but because of the state's interest in preserving life and protecting the innocent victins of treatment refusals. It is the two latter interests that are paramount here.

The interest in preserving hife is at stake in most treatment refusal cases. In some, the patient is so debilitated, and his or her life would be so painful and limited, that the state's interest seenns less compelling. ${ }^{126}$ In others, however, the patient (usually a Jehovah's Witness) could, if treated, enjoy a healthy and robust life. ${ }^{127}$ Significantly, even in the latter case, courts today hold that the patients' right to privacy overrides the state's interest in preserving life. As the influential President's

124. D. MEYERS, supra note 115 , at 249.

125. Interviews with Dr. Wayne Cohen, Director of Obstetrics and Gynecology, Bronx Municipal Hospital Center, and Associate Professor of Obstetrics and Gynecology, Albert Einstein College of Medicine in Bronx, N.Y. (June 5, 1985) [hereinafter Cohen Interview]; and Dr. George Kleiner, Director of Obstetrics and Gynecology, North Central Bronx Hospital, and Professor of Obstetrics and Gynecology, Albert Einstein College of Medicine in Bronx, N.Y. (Oct. 1, 1985). Two medical ethicists have argued that the woman and doctor can simply agree in advance as to the extent to which her care during pregnancy will place her needs before the baby's or the baby's before hers. Ruddick \& Wilcox, supra note 5 , at 12.

126. See, e.g., In re Quackenbush,156 N.J. Super. 282, 383 A.2d 785 (1978) (amputation needed on both legs); Lane v. Candura, 6 Mass. App. 377, 376 N.E.2d 1232 (1978) (leg amputation).

127. See, e.g., In re Osborne, 294 A.2d 372 (D.C. 1972); Melideo, 88 Misc.2d 974, 390 N.Y.S.2d 523. 
Commission for the Study of Ethical Problems in Medicine has stated, "a competent patient's self-determination is and usually should be given greater weight than other people's views on that individual's wellbeing." 128 We may conclude, then, that if the woman's life were the only one threatened by vaginal dehivery, most courts would, albeit sadly and reluctantly, uphold her refusal. ${ }^{129}$ But cases involving refusals of nonpregnant patients give no guidance to our evaluation of the state's interest in protecting the fetus's life. In this case, it is helpful to consider the state interest in protecting dependent third parties.

On occasion, courts have overridden coinpetent refusals to protect dependent third parties from loss of a parent. For example, several cases from the 1960's refused to uphold Jehovah's Witnesses' refusal of blood transfusions in part because of the patient's dependent children. ${ }^{130}$ Although the precedential value of these early cases is debatable, because patients' rights were not well established in the 1960's and because the patient's competency in the Georgetown case was uncertain, ${ }^{131}$ a New York court recently refused to let a young Jehovah's Witness mother "abandon" her child by refusing blood. ${ }^{132}$ Other courts have upheld patient refusals but taken this interest into account. For example, in In re Osborne, the court upheld a father's refusal noting that even if he died, his children's financial and emotional needs would be met by close rela-

128. President's Commission for the Study of Ethical Problems in Medicine and Biomedical aNd Behavioral Research, Deciding to Forego Life-Sustaining TREATMENT 27 (1983). Some commentators question whether states even have an interest in preserving life when such preservation requires medical intrusion on a person who competently refuses it. See Glantz, Legal Limits on the Rights to Refuse Treatment, in DILEMMAS OF DYING 53, 56 (C. Wong \& J. Swazey eds. 1981).

129. In In re Jamaica Hosp., N.Y.L.J., May 17, 1985, at 15, col. 4 (N.Y. Sup. Ct.), for example, a judge ordered a blood transfusion for a pregnant Jehovah's Witness and specifically noted that if her's were the only life at stake, he would respect her right to refuse.

130. See In re President of Georgetown College, 331 F.2d 1000, 1008, (D.C. Cir.) cert. denied 377 U.S. 978 (1964); Powell v. Columbia Presbyterian Medical Center, 49 Misc. 2d 215, 267 N.Y.S.2d 450 (Sup. Ct. 1965).

131. See $331 \mathrm{~F} .2 \mathrm{~d}$ at 1007 . Also, in some cases there were indications that the patient would accept a transfusion if ordered by the court, though he would not himself consent. See, e.g., In re Powell, 49 Misc. 2d 215, 267 N.Y.S.2d 450 (Sup. Ct. 1965). Some commentators argue that virtually all Jehovah's Witnesses cases that have overridden competent refusals have involved patients who subtly indicated that while they could not consent to a transfusion, their religious precepts would not be violated if the court ordered one. See Glantz, supra note 128, at 54.

132. In re Winthrop Univ. Hosp., 128 Misc. 2d 804, 490 N.Y.S.2d 996 (Sup. Ct. 1985). Nonetheless, this case may be distinguished from cases in which nonconsensual emergency treatment was mandated. The patient in Winthrop did not require an emergency transfusion to save her life. Instead, this case involved the refusal to authorize a blood transfusion in the event it was needed during a planned surgery. In the face of the surgeon's refusal to operate without this authorization the court ordered authorization for the transfusion, noting that the patient was free to leave or to select another doctor. Id. at 804,490 N.Y.S.2d at 997. According to John Fletcher, a judge in Maryland recently ordered blood transfusions for a woman near death after childbirth. See Fletcher, supra note 5 , at 34 . 
tives and the ongoing family business. ${ }^{133}$ Other courts have simply held that the parent's competent decision supersedes the state's interest in protecting children from the loss of a parent. ${ }^{134}$ Still others have upheld refusals without even discussing whether the state has an interest in protectimg the child from being orphaned. ${ }^{135}$ It is unclear then how much weight, if any, courts will give this interest.

Nonetheless, the weight courts should give this interest is, I believe, perfectly clear. Their understandable, yet inisguided, benevolence should never override a parent's competent refusal. ${ }^{136}$ In Osborne, the discussion of the material resources available for Mr. Osborne's children if he died illustrates one reason why this interest should never prevail. If taken seriously, courts inay honor the wishes of a parent with adequate funds or life insurance, and may override the wishes of one lacking these resources. ${ }^{137}$ Similarly, the decision of a single parent without close relatives would be given less deference than that of a parent blessed with close coinpanions. Considering the degree of emotional or fiscal harm that may occur leads to indefensible distinctions between rich and poor, solitary and socially connected. Ignoring it leads to inandatory treatment of anyone with a child. Because either outcome is unacceptable, this interest should never outweigh a conipetent refusal.

Overriding coinpetent parents' refusal of treatment also draws an invidious distinction between these parents, who are not permitted to "abandon" their children im this way, and other parents, who are allowed to abandon their children in other ways, such as placing thein for adop-

133. In re Osborne 294 A.2d 372, $374-75$ (D.C. 1972); see also A.B. v. C., 124 Misc. $2 \mathrm{~d} 672$, 675,477 N.Y.S.2d 281, 283 (Sup. Ct. 1984) (patient's request that she be held competent to decide to terminate medical care nonjusticiable because there was no actual controversy, but the court noted that it would uphold refusal in actual controversy in part because the son would be adequately cared for by father and siblings).

134. See In re Pogue, No. M-18-74 (D.C. Super. Ct. Nov. 11, 1974), reported in Washington Post, Nov. 14, 1974, § C, at 1, col. 1, and discussed in J. GoldstelN, A. Freud \& A. Solnit, BEFORE THE BEST INTERESTS OF THE CHILD $95-96$ (1979) (authorizing blood transfusion for newborn infant but refusing to order one for infant's mother because her adult status, despite her parental duties, entitled her to refuse blood for herself).

135. See Mercy Hosp. v. Jackson, 62 Md. App. 409, 489 A.2d 1130 (1985) vacated on other grounds, $306 \mathrm{Md}$. 556, 510 A.2d 562 (1986) (refusing to appoint guardian to consent to blood transfusion for competent pregnant woman who refused blood during Cesarean delivery, holding that at least where fetus was not at risk refusal had to be honored).

136. The Georgetown case has been severely criticized. For example, Justice (then judge) Warren Burger, in dissenting from the D.C. Circuit's refusal to review, argued that hospitals have no legally recognized right to require patients to accept standard medical treatment. Justice Burger quoted Cardozo on judicial restraint: "The judge, even when he is free, is still not wholly free. He is not to innovate at pleasure. He is not a knight-errant, roaming at will in pursuit of his own ideal of beauty or of goodness. He is to draw his inspiration from consecrated principles. He is not to yield to spasmodic sentiment, to vague and unregulated benevolence." In re President of Georgetown College, 331 F.2d at 1017 (D.C. Cir. 1964) (Burger, J., dissenting) (quoting B. CARDozo, THE NAtURe of the Judicial Process (1921)).

137. See Glantz, supra note 128 , at 58 . 
tion or in foster care. The unfairness of this distinction is heightened by the fact that refusal of treatment does not always result in death and "abandonment." 138 Rather, refusals merely increase the risk of abandonment. Yet parents take all sorts of health risks, from sky diving, to abusing drugs or alcohol, to joining the United States Army, that are not subject to state intervention. It is puzzling that parenthood should vitiate the right to refuse treatment when it leaves intact the freedom to act in other ways equally detrimental to a child. Most probably courts, like doctors, are extremely distressed at the prospect of a young person dying a preventable death, and seek some justification for avoiding this outcome. The presence of dependent children is a convement and colorable justification. But logically, that presence cannot justify denying parents the freedom of choice allowed other adults. If there is to be a social commitment to patient autonomy, parenthood should not undermine that autonomy-tragic as the consequences sometimes are.

If accepted, this conclusion invalidates the argument that if a parent's refusal may be overridden simply to protect a child from emotional and fiscal harm, then it surely may be overridden to safeguard a child's very life. ${ }^{139}$ The conclusion that refusals that may orphan a child must nonetheless be honored does not, however, necessarily imply that refusals that may kill or mjure a fetus must be honored as well. In the latter case, the state has a strong interest im preserving the life of the unborn child. But how far should courts go in protecting life when such protection requires nonconsensual treatment of another? It seems reasonable to hold that the state's power to protect a child in utero (even one about to be born) should not exceed its power to protect imdependently existing individuals. We must ask, then, what interventions a state may mandate to protect a third party in peril.

\section{B. Interventions to Protect Others}

Not surprisingly, very few cases involve performing a medical procedure on one person in order to save the hife of another. This dearth of precedent is partially explained by the highly unusual factual circumstances such cases require-that an organ or bodily substance of $A$, and

138. Mr. Osborne, for example, lived even though he did not receive blood. See In re Osborne, 294 A.2d 372, 376 n.6 (D.C. 1972).

139. Even if transfusions were routinely ordered on Jehovah's Witness parents, this would not necessarily mean that Cesareans could be mandated as well. For one thing, the transfusion benefits (objectively speaking) the Jehovah's Witness himself or herself, because it saves his or her life. This was also true in Raleigh Fitkin-Paul Morgan Memorial Hosp. v. Anderson, 42 N.J. 421, 201 A.2d 537 (1964), where the court ordered a transfusion for a pregnant Jehovah's Witness. In most obstetric cases, the Cesarean recommended is entirely for the fetus's benefit-placenta previa being an exception. Additionally, the risk involved in a Cesarean far exceeds that from a transfusion. In other areas, courts order some bodily invasions but refuse to order invasive or risky ones. See infra text accompanying notes 178-206. 
only $A$, may potentially save $B$, yet $A$ refuses to donate it. Additionally, few people in even such desperate straits as $B$ are likely to try to compel donation by $A$, because this goes so strongly against the grain of American insistence on bodily integrity, autonomy, and nonsubordination. The general law concerning the duty (or lack of duty) to rescue illustrates this. The following discussion will first briefly review the principles of Samaritan law and then will examine the few cases that consider bodily interventions intended to aid a third party.

With limited exceptions, Anglo-American law imposes no duty to come to the assistance of a person in distress. ${ }^{140}$ One exception provides that one who imjures or imperils another has a duty to render aid. ${ }^{141}$ Another exception requires that a person who begins a rescue attempt perform it with reasonable care, and that she not abandon the effort if doing so will leave the imperiled person in a worse position than before. ${ }^{142}$ For our purposes, the most important exception is that some special relationships between the parties justify imposing a duty to rescue. ${ }^{143}$ Special relationships clearly include those such as innkeeper to guest, cominon carrier to passenger, and jailer to prisoner. ${ }^{144}$ They also include such fundamental relationships as parent and child, ${ }^{145}$ and it has been suggested that other fundamental relationships, such as husband and wife, should also be recognized as giving rise to a duty to rescue. ${ }^{146}$ These exceptions imitigate the harshness of the general principle that one may be a 'bad Sainaritan,' a controversial principle that many commentators have long criticized as being callous and indifferent both to moral duties and to human life. ${ }^{147}$

140. W. Prosser \& W. Keeton, The LaW of TORTS $\$ 56$, at 375 (5th ed. 1984). This fundamental "no duty to rescue" rule is often illustrated with highly disturbing examples. For example: "The expert swimmer, with a boat and a rope at hand, who sees another drowning before his eyes, is not required to do anything at all about it, but may sit on the doek, smoke his cigarette, and watch the man drown." Id. (citing Osterlind v. Hill, 263 Mass. 73, 160 N.E. 301 (1928)).

141. Id. at 377.

142. 57 AM. JUR. 2d Negligence $\$ 46$ (1971). In addition, persons such as lifeguards, policc, and firefighters, whose jobs require them to undertake rescues, have contractually assumed duties to rescue that are more extensive than duties that are not explicitly assumed and compensated. See W. LAFAVE \& A. SCOTT, supra note 99, § 26, at 185.

143. W. Prosser \& W. KeEton, supra note 140, at 376-77.

144. Id. at 376.

145. See G. Fletcher, Rethinking Criminal LAW 612 (1978) (familial relationships like parent-child or husband-wife give rise to duties to prevent harm); see also W. LAFAVE \& A. ScoTT, supra note 99 , at 189 . As they put it, "A parent must doubtless leave his companions in the middle of an interesting bridge hand to rescue his smothering baby." Id.

146. G. FLETCHER, supra note 145, at 612; W. PrOSSER \& W. KEETON, supra note 140, at 377.

147. See, e.g., Ames, Law and Morals, 22 HARv. L. REv. 97, 113 (1908) (legal duty should be adopted to reflect and reinforce moral obligation to help one's neighbor); D'Amato, The "Bad Samaritan" Paradigm, 70 Nw. U.L. REv. 798 (1975) (proposing criminal sanctions for failing to rescue); Silver, The Duty to Rescue: A Reexamination and Proposal, 26 WM. \& MARY L. REV. 423, 425-26, 445 (1985). 
Whatever one's view about the general rule, one feature of the law of rescue is quite uncontroversial: even when rescue is required, rescues that risk life or limb are, and should remain, optional. Persons to whom the various exceptions apply have an obligation to take only rather minimal action, such as warning of danger ${ }^{148}$ or calling a doctor or other proper authorities. ${ }^{149}$ The few states that have statutorily created a duty to rescue require only such assistance as can be rendered without danger to the rescuer. ${ }^{150}$ It would, therefore, be an extraordiniary revision of American law to require risky rescues, even by a spouse or parent.

In McFall v. Shimp, ${ }^{151}$ the court wisely recognized that a plaintiff's claim to niandatory medical imtrusion on another so that the plaintiff's life might be saved fell under the rubric of Samaritan law. Robert McFall was a victim of aplastic anemia who sought to force David Shimp, his cousm, to donate bone marrow to him. Although bone niarrow extraction is far less risky than major surgery, it is painful and invasive, requiring multiple insertions of a curved needle into the iliac bones while the donor is under anesthesia. ${ }^{152}$ Shimp underwent mitial tests to determine bone inarrow compatibility, and was found to be the only fainily inember with potentially coinpatible bone inarrow. He then refused to undergo further testing. ${ }^{153}$ Although the court found the defendant's conduct morally reprehensible, ${ }^{154}$ it refused to order him to complete the testing and, if found compatible, to donate. The court emphasized that there is no legal duty to rescue others, and stated that to require this Sainaritan act "would change every concept and principle upon which our society is founded." 155 It continued:

For a society which respects the rights of one individual, to sink its teeth into the jugular vein or neck of one of its members and suck from it sustenance for another member, is revolting to our hard-wrought concepts of jurisprudence. Forceable extraction of living body tissue causes

148. See, e.g., Scateba v. Pittsburgh \& New England Trucking, 2 Mass. App. Ct. 683, 319 N.E.2d 730 (1974) (imposing duty on driver of disabled vehicle, even though free of fault, to set out flares or otherwise warn oncoming traffic).

149. See Regan, supra note 96 , at 1596.

150. See MinN. STAT. ANN. $\S 604.05 .01$ (West. Supp. 1986); VT. STAT. ANN. tit. 12, § 519(a) (1973). European countries, which generally do require rescue, likewise exempt physically hazardous rescues. See, e.g., C. PEN. art. 63 (Fr.).

151. 10 Pa. D. \& C.3d 90 (1978).

152. For a description of bone marrow extraction, see L. KASS, Bone MARRow INTERPRETATION 389-91 (2d ed. 1985). The plaintiff's physician in McFall characterized the risks to the donor as "very acceptable." Comment, Coerced Donation of Body Tissues: Can We Live with McFall v. Shimp?, 40 OHо ST. L.J. 409, 411 n.19 (1979). Under the informed consent doctrine, however, risks cannot be deemed acceptable or unacceptable in the abstract. Rather, they must be considered acceptable by the person who will undergo them.

153. $10 \mathrm{~Pa}$. D. \& C.3d at 90.

154. Id. at 91 .

155. Id. 
revulsion to the judicial mind. Such would raise the spectre of the swastika and the Inquisition, reminiscent of the horrors this portends. ${ }^{156}$

Thus, the court would not order this invasion of Shimp's body even though Shimp's refusal to donate ineant death for McFall. ${ }^{157}$

McFall is a sad case, but it was not, as the court's strong and even lurid language indicates, a hard one. The principles of privacy, autonomy, and bodily integrity compel the conclusion that however repugnant the refusal to aid may be, the courts cannot mandate assistance of this nature and magnitude. This conclusion almost certainly would not differ had the case involved a father and child. ${ }^{158}$ Mandatory organ donation is a standard scholarly example of a practice that would unquestionably lie beyond the limits of the law. ${ }^{159}$ As Angela Holder states, "In no case is an adult ever ordered to surrender a kidney, bone marrow, or any other part of his body for donation to his child, to another relative, or to anyone else."160 Likewise, Donald Regan asks rhetorically, "Would a court inpose criminal liability on anyone, even the child's parent, who did not attempt to save the child at the risk of second-degree burns over one or two per cent of his or her body?"161 Because risky rescues have never been required, even of parents, we inust conclude with Holder and $\operatorname{Regan}^{162}$ that courts would not coinpel a parent to donate bone marrow to a dying child.

This conclusion is supported by In re George, ${ }^{163}$ another sad case in which a thirty-three-year-old adoptee suffering from chronic myelocytic leukemia sought a court order to open his adoption records so that he could locate a coinpatible bone inarrow donor. The judge consulted the man's natural mother, who was tested but found not compatible. The judge then contacted the alleged natural father, whose name was obtamed froin the adoption records. The man denied paternity and was unwilling to be tested for compatibility. The matter stopped there; the court refused to give the dying inan lis natural father's name. ${ }^{164}$

156. Id. at 92 (emphasis in original).

157. McFall died two weeks after the case was filed. See Comment, Coerced Donation, supra note 152 , at 414 .

158. Nothing in the court's opinion indicates that the degree of relationship was significant. The holding was based on the sanctity of the individual and the general law of rescue.

159. See L. TR1BE, American Constitutional LAw 918 (1978); Kadish, Respect for Life and Regard for Rights in the Criminal Law, in RESPECT FOR LIFE IN MEDICINE, PHILOSOPHY, AND THE LAW 83, 94-95 (1977).

160. A. HOLDER, supra note 67 , at 178 .

161. Regan, supra note 96 , at 1588 (arguing that restrictions upon abortion impose unparalleled Samaritan duties upon women).

162. Id. at 1586.

163. 630 S.W.2d 614 (Mo. Ct. App. 1982).

164. Id. at 619 . In Head v. Colloton, 331 N.W.2d 870 (Iowa 1983), a leukemia victim sought to compel a hospital to disciose the identity of a potential unrelated bone marrow donor, listed in the hospital's bone marrow transplant registry, so that the victim could contact the potential donor 
Ordering a Cesarean to save the fetus is just as extraordinary as ordering a parent to donate bone marrow to save a child. Even so, courts faced with these cases have not recognized this. This is probably because the Cesarean cases seem different. The woman is going to give birth anyway-if she just agrees to a surgical dehvery rather than insisting on a vaginal one, the baby will survive unharmed. If she refuses, the harm to the baby will be both immediate and in the same location as the woman (literally). In contrast, the victim who is refused a bone marrow donation will succumb inore slowly and, perhaps, out of sight. In addition, it is the doctor, with his or her persuasive professional authority, who seeks the Cesarean rather than the individual victim.

These differences inay affect the emotional responses of participants and judges. They do not, however, legally distinguish the refusals. In each case, a parent is refusing an invasive and somewhat risky procedure without which his or her child will die or suffer severe harnn. John Robertson, a proponent of mandatory Cesareans in certain circumstances, accepts this equivalency, and hence supports compulsory parental "donations" of blood, bone marrow, and perhaps even organs, depending upon the degree of risk. ${ }^{165}$ Robertson's consistency of approach helps to deinonstrate the equivalency of the two situations. Once equated, however, the degree to which a court-ordered Cesarean violates fundamental tenets of American law also becomes clear: logical consistency demands that if Cesareans can be required, American law concerning duties to rescue must be radically restructured.

It might be objected that a pregnant woman is a special case because the voluntary act of continuing a preguancy creates special obligations over and above the duty to rescue imposed upon all parents. A further objection might claim that carrying a fetus to tern but refusing a Cesarean inay cause the child to be far worse off-profoundly retarded, for exainple-than if it had never been conceived. ${ }^{166}$ If construed as suggesting that the woman fits into an additional exception to the "bad Samaritan" principle as someone who has begun a rescue, these arguinents are still insufficient to create a legal duty to run physical risks for the sake of the fetus. ${ }^{167}$ Even if one takes the position that a woman who

personally. The potential donor had been previously tissue-typed for a possible blood platelet donation to a relative. In this instance, she was contacted. She indicated that she did not wish to donate to a nonrelative. The court refused to order the hospital to give her name to the plaintiff, because of a person's right to avoid disclosure of personal matters.

165. Robertson, supra note 7, at 354-55.

166. This is unlike the case of abortion. As Regan emphasizes, the exception to the "bad Samaritan" principle for someone who has voluntarily begun a rescue is inapplicable to the woman who does not want to be pregnant, Regan, supra note 96, at 1594-98. Moreover, her entire course of conduct would not make the fetus any worse off than if she had never conceived, since nonexistence is the outcome in either case. Id. at 1599.

167. It could be argued that she fits into a third exception-having caused the fetus's peril. The 
has carried a pregnancy to term has embarked upon a course of action vis a vis the fetus that may be viewed as a rescue and that may arguably allow certain demands to be placed upon her, compulsory surgery goes far beyond demands imposed on other voluntary rescuers. ${ }^{168}$ For example, the person who begins to rescue a child trapped in a burning building but then realizes it is far more dangerous than he thought, would not have a duty to contimue the rescue despite the change in circumstances. ${ }^{169}$ In the Cesarean context, the mother's act of nurturing the fetus through pregnancy would not require that she undergo additional risks to ensure its safe passage into the world.

Perhaps, though, this legalistic interpretation does not do justice to the claim that the woman has assumed special obligations. Surely what is meant by the claim is not coinpletely captured by the argument that at the time of delivery multiple exceptions to the "bad Samaritan" principle may apply. Rather, the real thrust of this objection seems to be that the woinan is physically and morally responsible for the life within her, and she ought to do more than the minimum to promote its welfare. The extent of a pregnant woman's moral obligations to her developing fetus merits serious consideration, especially as we learn more about substances that may harm the fetus. Fortunately, most woinen in our society take these obhgations very seriously, even subordinating their desires for such things as alcohol, cigarettes, or caffeine to the interests of the fetus. But in this very private and bodily sphere, the issue of moral obligations, even very compelling ones, must be kept distinct from the issue of legal coercion of individuals to meet their moral obligations. The law of rescue condones many omissions that are morally reprehensible. For that

woman in cases involving obstetrical dangers has not, however, caused the danger in any normal sense of the word. She is merely its locus. In the context of placenta previa or fetal distress, it is no more sensible to say that she caused the peril than it is to say that the fetus put her in this potentially dangerous situation. A more accurate description would be the situation of two people trapped on a crumbling ledge which cannot support both of them for long. If the woman on the left jumps, she has a very good chance of landing on another ledge 30 feet below, but a slight chance of missing it and falling 300 feet to her death. If the man on the right jumps, he is more likely to fall the 300 feet, but could possibly land on the ledge 30 feet below and survive. One might hope that the woman would jump because this is more likely to lead to the best overall outcome. But because she is also a victim of this situation, she has no legal obligation to jump. For that matter, given the risk to her, she would not have such a duty even if she had caused the peril. Taking a risk, even a fairly small one, of death, and undergoing physical hardship in any event, is not required even where there is a duty to rescue. Jumping 30 feet, or submitting to a Cesarean, is very different from, for examplc, setting out flares to warn oncoming traffic of one's disabled vehicle.

168. In the abortion context, Regan puts this as follows:

The pregnant woman is not totally uninvolved. She is sufficiently involved that we could appropriately impose slight burdens of aid on her, if imposing slight burdens would do the fetus any good. Unfortunately, imposing slight burdens on her will not do the fetus any good. It is very large burdens or nothing.

Regan, supra note 96 , at 1591.

169. See Regan, supra note 96 , at 1600 (pointing out that a rescue which turns out to involve a long and burdensome effort can surely be terminated). 
matter, refusal to undertake risky rescues does not normally even invoke moral opprobrium. Morally, we seem to have a different standard for pregnant women. But this moral standard does not justify an unparalleled level of legal constraint.

Although there are no other cases involving refusal to donate a bodily organ, in a number of cases parents have sought court permission to authorize an incompetent sibling to donate a kidney to a sibling suffering from renal failure. Solne courts have granted this permission. ${ }^{170}$ One commentator has suggested, in an extraordinary interpretation of these decisions, "that there is a rather stringent duty to prevent or reinove harm, or both, to a ineinber of one's immediate family, a duty that involves significant risk to oneself and is shared even by ineinbers of the fainily who are incoinpetent to shoulder other types of obligations."171 She concludes that cases authorizing donation by incoinpetents can constitute a legal precedent for coinpelling parents to undergo invasive medical procedures, including organ donation, for the sake of their children and, of course, for analogous forns of prenatal coinpulsion. ${ }^{172}$

Cases authorizing donation from incoinpetents have not even hinted that the incompetent has a inoral or legally enforceable obligation to donate. In fact, there is little doubt that even an incoinpetent refusal would be sacrosanct. ${ }^{173}$ The problem is that could he or she understand the issue, the potential donor might, or might not, wish to donate. Many courts faced with these cases have used the substituted judgment test, which asks what the incoinpetent would inost likely want. When courts have permitted donation, they have stressed the incompetent's probable anguish at the sibling's death. ${ }^{174}$ Other courts have rejected the claim that the proper test is whether the incoinpetent would consent to donate if he could do so, and have simply refused to authorize the transplant on the grounds that it is not in the best interest of the incompetent. ${ }^{175}$ Soine might argue that in the cases that authorize donation, the imputation of

170. See, e.g., Hart v. Brown, 29 Conn. Supp. 368, 289 A.2d 386 (1972); Strunk v. Strunk, 445 S.W.2d 145 (Ky. 1969).

171. Mathieu, Respecting Liberty and Preventing Harm: Limits of State Intervention in Prenatal Choice, 8 HARv. J.L. \& PuB. Pol'y 19, 43-44 (1985) (footnote omitted).

172. Id. at 44. Mathieu claims that one of the deciding factors in Strunk was the obligation of one family member to undergo risks for another, though she notes that this factor was not stated in the case. I suggest that the reason it was not stated is that it was not there and could not have been used.

173. See A. Holder, supra note 67 , at 183 (trial judges in cases involving minor donors have all made sincere efforts to ascertain child's wishes: "[ $t$ ]he implication is that they would have respected a refusal as conclusive").

174. Strunk, 445 S.W.2d at 146-47; Hart, 289 A.2d at 389; Little v. Little, 576 S.W.2d 493, 49899 (Tex. Civ. App. 1979).

175. See, e.g., In re Richardson, 284 So. $2 \mathrm{~d} 185$ (La. Ct. App. 1973) (minor has right to be free from bodily intrusion unless it is in his best interests); In re Pescinski, 67 Wis. 2d 4, 226 N.W.2d 180 (1975) (rejecting substituted judgment test and refusing to allow transplant). 
devotion and altruism to the incompetent is somewhat suspect. But even if some courts exaggerate notions of filial devotion to allow donation, the focus of the substituted judgment test on the imcompetent's probable desires demonstrates that refusal would also be honored.

The law of donations froin the dead also reflects the absence of a legal obhigation to donate. The current law is that organs cannot be removed unless either the person had, when alive, indicated his donative intent, or consent from the family is obtamed. ${ }^{176} \mathrm{~A}$ person opposed to donation may refuse to donate both for "good" reasons-religious beliefs, for example - and for "bad" ones ("if I can't live, I don't want to help someone else to hive"). Proposals to revise the law to increase the supply of available organs would merely reverse this presumption; routine removal would be allowed unless the individual had previously indicated opposition, or the family objected when informed of this practice. ${ }^{177}$ In other words, such proposals still would not violate the prior choices of the deceased by nonconsensual organ removal. Certainly, by way of comparison, an organ taken from a cadaver can save a life just as an emergency Cesarean can. Yet, respect for individual choice extends even to those decisions that can be exercised only after a person's death. In this way, forcing women to undergo major surgery emerges as an anomalous and inconsistent derogation of individual choice.

\section{Interventions to Promote Other State Interests}

Although compulsory bodily invasion to rescue a third party is the closest analogy to the court-ordered Cesarean dilemma, it is helpful to consider briefly the other areas in which nonconsensual bodily invasions are at stake. These include compulsory vaccinations, intrusions to obtain evidence from criminal suspects, and nonconsensual treatment of institutionalized persons. Although the state interests differ in these cases, taken together the decisions in these areas demonstrate the limits of nonconsensual bodily invasions. A brief examination of these cases will show that in no other area do courts countenance invasions as substantial as Cesarean sections. This is significant because it leaves the compulsory Cesarean order even further from the mainstream of American jurisprudence.

Compulsory vaccination is constitutionally permitted, although it is certainly an infringement of an individual's bodily integrity, privacy, and autonomy. ${ }^{178}$ Compulsory vaccination is of little relevance in the Cesarean context, however. First, the degree of invasion and risk caused

176. See UNIF. ANATOMical GifT ACT \#2, 8A U.L.A. 34 (1983).

177. See Matas, Arras, Muyskens, Tellis \& Veith, A Proposal for Cadaver Organ Procurement: Routine Removal with Right of Informed Refusal, 10 J. HEALTH POL., PoL'Y \& L. 231 (1985).

178. See Jacobson v. Massachusetts, 197 U.S. 11 (1905). 
by vaccination is strikingly incominensurate with that of major surgery. In addition, the state interest involved is the very public one of protecting all citizens from the perils of epidemic disease. In the face of such a generalized and public interest, certain invasions of individual autonomy may be justified to protect the public good that would clearly be imiperinissible were the purpose a private one. For example, Regan notes that although laws requiring compulsory military service may appear to be an exception to the "bad Samaritan" principle, they really are not because a draftee is not called to benefit another individual, but to serve the broader interest of defending his country. As he points out, "Rightly or wrongly, our tradition distinguishes between obligations to aid particular individuals and obligations to promote a more broadly based public interest." 179

The criminal area is more helpful. Courts have struggled with a wide spectruin of bodily invasions that raise fourth amendinent issues and involve the rights to privacy and bodily integrity, and some ininor, relatively nominvasive procedures have passed constitutional scrutiny. In Schmerber v. California, ${ }^{180}$ for example, the Supreme Court held that a compulsory blood test to determine alcohol content was not an unreasonable search and seizure. The Court set forth a balancing test, that weighs the individual's privacy and security interests against society's interests in conducting the procedure, to determine the reasonableness of a bodily intrusion. ${ }^{181}$ Because the blood test involved virtually no risk, trauma, or pain, the Court held that the state's imterests in enforcing laws against driving while intoxicated outweighed the suspect's privacy riglit. ${ }^{182}$ The Court stressed, however, that " $t$ t]he integrity of an individual's person is a cherished value of our society" and that authorizing this minor intrusion did not imply that more substantial intrusions would be permissible. ${ }^{183}$

Indeed, the Court has generally disapproved more extensive bodily invasions. In Rochin v. California, ${ }^{184}$ police broke into the rooin of a person suspected of selling narcotics. They saw him place two capsules in his inouth and unsuccessfully tried to force his inouth open. They then took him to a lospital and instructed a doctor to force an emetic solution into his stomach through a tube. ${ }^{185}$ The Court noted its strong disapproval of these actions:

Illegally breaking into the privacy of the petitioner, the struggle to open

179. Regan, supra note 96 , at 1606.

180. 384 U.S. 757 (1966).

181. Id. at 766-72.

182. Id. at 771 .

183. Id. at 772 .

184. 342 U.S. 165 (1952).

185. Id. at 166. 
his mouth and remove what was there, the forcible extraction of his stomach contents-this course of proceeding by agents of government to obtain evidence is bound to offend even hardened sensibilities. They are methods too close to the rack and the screw to permit of constitutional differentiation. ${ }^{186}$

Because the Court's condemnation was aimed at the entire course of proceedings, rather than solely at the type of bodily search undertaken, it is not entirely clear when forced regurgitation to obtain evidence will be allowed. ${ }^{187}$ It will be allowed in situations where good faith use of an enetic is in the defendant's best interests, because digestion of the swallowed contraband will cause him harm. ${ }^{188}$ Concomitantly, it will not be authorized when the contraband is in an insoluble container that will pass through the digestive tract intact inaking regurgitation unnecessary for obtaining the evidence. ${ }^{189}$ While it is unclear if use of an emetic will be allowed where it will not benefit the defendant, but is the only way to obtain the evidence, ${ }^{190}$ it is fair to say that courts will scrutinize such a request very closely for probable cause, public necessity to prove the offense, impact on defendant, reasonableness of manner used, and the availability of less intrusive alternatives. ${ }^{191}$

The intrusion of surgery is strongly disapproved. The Supreme Court recently held that risky and invasive surgery cannot be imposed, even upon a criminal suspect. In Winston v. Lee, ${ }^{192}$ law enforcement authorities wanted to obtain for evidence of criminal involvement a bullet lodged in the defendant's chest. The proposed surgery required general

186. Id. at 172 .

187. See 2 W. LAFAVE, SEARCh AND SEIzURE: A TREATISE ON THE FourTh AMENDMENT $\S 4.1$, at 13; $\$ 5.3$, at 327 (1978 and Supp. 1986). A case allowing use of an emetic, Blefare v. United States, 362 F.2d 870 (9th Cir. 1966), emphasized that the manner of administration was distinguishable from Rochin's course of proceedings. Nonetheless, LaFave criticizes the reasoning of Blefare, noting that the majority erroneously believed that the use of an emetic was different from the Rochin procedure which it called "stomach pumping," 2 W LAFAVE, supra, at § 4.1, at 13 n.53, and distinguishes the case's circumstances as unique to the border search. Id. at $\S 4.1$, at $13 \mathrm{n} .52 ; 3$ W. LAFAVE, supra, § 10.5, at 294-95 (1978).

188. See, e.g., United States v. Owens, 475 F.2d 759 (5th Cir. 1973); People v. Jones, 20 Cal. App. 3d 201, 97 Cal. Rptr. 492 (1971); see also People v. Bracamonte, 15 Cal. 3d 394, 540 P.2d 624, 124 Cal. Rptr. 528 (1975) (holding unreasonable a search not made under proper warrant but noting that a stomach search could be justified if balloons containing narcotics would likely break open inside suspect's digestive tract and endanger his health and allow destruction of the evidence).

189. See People v. Rodriguez, 71 Cal. App. 3d 547, 557-58, 139 Cal. Rptr. 509, 514 (1977); Bracamonte, 15 Cal. 3d at 403-04, 540 P.2d at 630-31, 124 Cal. Rptr. at 534-35 (1975); Comment, Analyzing the Reasonableness of Bodily Intrusions, 68 MARQ. L. REv. 130, 146 (1984).

190. In Bracamonte, the court noted that had there been evidence that the balloons would likely break open in the digestive tract, "not only would the potential health hazard possibly justify the intrusion into defendant's stomach, but the fear of the destruction of evidence might also justify remedial action." $15 \mathrm{Cal}$. 3d at 404; 540 P.2d at 631, 124 Cal. Rptr. at 535.

191. See Comment, supra note 189, at 152-53; Comnent, Constitutionality of Stomach Searches, 10 U.S.F. L. REv. 93, 98-99 (1975).

192. 470 U.S. 753 (1985). 
anesthesia, and there was uncertainty as to the size of incision necessary and the time the operation would require. ${ }^{193}$ The circuit court had refused to authorize the state to "drug this citizen-not yet convicted of a criminal offense- -with narcotics and barbituates into a state of unconsciousness," and then search beneath his skin for evidence of a crime. ${ }^{194}$ The Supreine Court affirmed, holding that the intrusion on the defendant's privacy interests was severe ${ }^{195}$ and that " $[t]$ he inedical risks of the operation, although apparently not extremely severe, are a subject of considerable dispute; the very uncertainty militates against finding the operation to be "reasonable." "196

Winston v. Lee did not hold that any and all bodily intrusion was necessarily unconstitutional. The Court adhered to the balancing test set forth in Schmerber, and weighed the state's need for the evidence against the risk to the defendant's health and the degree of invasion of his privacy. ${ }^{197}$ The Court noted that characterization of surgery as "1najor" or "minor" was not necessarily controlling, ${ }^{198}$ but approved the district court's consideration of factors such as size and depth of incision, length of time for surgery, risk of infection, and type of anesthesia. ${ }^{199}$ These factors, however, are precisely those that differentiate a significant procedure froin a quick, nonrisky, "minor" one. Inasmuch as Cesarean dehvery is unquestionably inajor, risky surgery, the Winston Court's analysis strongly indicates that a state-ordered Cesarean would be an unconstitutional invasion of a wornan's privacy even in the face of substantial state interests. ${ }^{200}$

\footnotetext{
193. Id. at 756-57.
}

194. Lee v. Winston, 717 F.2d 888, 901 (4th Cir. 1983).

195. Winston, 470 U.S. at 766.

196. Id.

197. Id. at 763 .

198. Id. at 764 n.8. Various commentators have proposed that major surgery is a per se violation of the fourth amendment. See, e.g., Note, Nonconsensual Surgery: The Unkindest Cut of All, 53 Notre Dame Law. 291, 303 (1977); see also Comment, Search and Seizure: Compelled Surgical Intrusions?, 27 BAYLOR L. REv. 305, 309-11 (1975) (reasonableness should be determined by the facts in each case, focusing on the risk to the defendant). United States v. Crowder, 543 F.2d 312 (D.C. Cir. 1976), cert. denied, 429 U.S. 1062 (1977) also supports this distinction. Crowder affirmed the lower court's finding that minor surgery to remove a bullet in the defendant's arm using a local anesthetic would not harm the defendant, stressing the time, risk, anesthesia, and surgical skill involved. The lower court had distinguished this arm surgery from that which would be required to remove another bullet from defendant's thigh, noting the possible permanent damage from that more involved procedure. The appellate court noted the "reasonableness" of allowing the minor operation and disallowing the more risky thigh surgery. Id. at 316.

199. Winston, 470 U.S. at 763-65.

200. The Winston Court not only discussed the extent of the surgery in terms of risk, but recognized the patient's control as a significant factor. It disapproved the "virtually total divestment of respondent's ordinary control over surgical probing beneath his skin." Id. at 765. Comparing a vaginal birth and a Cesarean delivery presents a strong disparity in both the patient's control in such procedures and the risks of the nonsurgical and surgical procedures. 
Cases examining punishment of prisoners and treatment of prisoners and inental patients further illustrate the judicial abhorrence of state imposition of physical risk, pain and invasion. As Regan suminarizes, "pumishment may not be too 'physical." "201 Prisoners cannot deliberately be denied medical treatment, ${ }^{202}$ hygienic facilities, or exercise opportumities. ${ }^{203}$ Even when treatment is for the institutionalized person's benefit, courts look with disfavor on painful, invasive, or risky procedures. Averse conditioning using injections of apomorphine to induce vomiting has been prohibited because of the "painful and debilitating" nature of the procedure. ${ }^{204}$ Considering both the risk of even coinmon medications and the right to privacy, some courts have recognized a protected liberty interest of the patient to refuse relatively nonintrusive treatment such as antipsychotic drugs. ${ }^{205}$ As one such court held: "[L]iberty includes the freedom to decide about one's own health. This principle need not give way to medical judgment."206

Clearly, in no other area are nonconsensual invasions of the magnitude of Cesareans authorized by law. As one writer notes, the fact that courts prohibit equivalent or lesser invasions even upon criminal defendants and inental patients, over whom the state traditionally exerts great authority, "suggests the radical nature of the fetal rights trend and its incompatibility with our heritage of civil liberties."207 Indeed, if courts continue to coinpel Cesareans, pregnant women will be subjected to intrusions deemed unconstitutional for any other person in society.

\section{The Equal Protection Implications}

The disparity between the degree of intrusion a court-ordered

201. Regan, supra note 96 , at 1584 .

202. Estelle v. Gamble, 429 U.S. 97, 103 (1976).

203. See, eg., Sinclair v. Henderson, 331 F. Supp. 1123, 1130-31 (E.D. La. 1971) (violation of eighth amendment to deny prisoners on death row exercise facilities); Wright v. McMann, 387 F.2d 519, 526 (2d Cir. 1967) (finding "strip cells" that provide inadequate hygienic facilities constitute cruel and unusual punishment), aff'd in relevant part, 460 F.2d 126, 129-30 (2d Cir.), cert. denied, 409 U.S. 885 (1972). About Sinclair, Regan says: "There is no logical contradiction in requiring that prisoners awaiting death must be allowed to exercise, or in permitting capital punishment while we have effectively abolished corporal forms, but there is a mild paradox that says something about our attitudes towards pain and physical suffering." Regan, supra note 96, at 1584.

204. Knecht v. Gillman, 488 F.2d 1136, 1140 (8th Cir. 1973).

205. Several cases have upheld state procedural safeguards against administration of drugs as adequate protection of recognized constitutional rights in treatment. See, e.g., Rogers v. Okin, 738 F.2d 1 (1st Cir. 1983); Rennie v. Klein, 720 F.2d 266 (1st Cir. 1983) (en banc). As Rcgan notes, there are various other issues involved in these cases, including procedural safeguards, the efficacy of the treatments, and the appropriateness of state-enforced "mind control." Regan, supra note 96, at 1585. But physical pain, risk, and intrusion are essential factors underlying these decisions.

206. In re K.K.B., 609 P.2d 747, 749 (Okla. 1980). Special restrictions limit even the seemingly consensual use of invasive treatments such as experimental psychosurgery. See Kaimowitz v. Dep't of Mental Health, 2 Prison L. Rep. (A.B.A.) 433, 476 (Mich. Ct. App. 1973).

207. Note, supra note 102 , at 617 . 
Cesarean imposes on a pregnant woman and the much greater respect for bodily integrity shown in all other situations clearly raises equal protection concerns. There are two possible responses to the argument that nonconsensual Cesareans violate the deinands of equal protection of the laws. The first is that there is no equal protection problem because no other situation is sufficiently similar to that of a pregnant woman with a viable unborn child to constitute a relevant comparison. The second is that in the most closely analogous case-where a parent's bone marrow or organs are needed to save the child-nonconsensual treatment should in some circumstances also be imposed. ${ }^{208}$

There is much good sense in the argument that pregnancy is sui generis and that a legal approach of arguing from analogies fails to reflect this. ${ }^{209}$ Pregnancy is umique, and we cannot pretend it is otherwise. The problein, however, is whether its umique status means that no other comparisons are even relevant for equal protection purposes. In terms of legal analysis, the Pregnancy Discrimination Act, ${ }^{210}$ which prohibits discrimination in einployment based on pregnancy, childbirth, or related medical conditions, undermines the claim that pregnancy cannot fruitfully be compared to other conditions. ${ }^{211}$ Likewise, in arguing that the Roe result would be better justified by the equal protection argument that prohibition of abortion would impose Samaritan burdens on pregnant women completely disproportionate to those imposed on anyone else, Professor Donald Regan acknowledges that there is no precise analogue to pregnancy. ${ }^{212}$ Nonetheless, he persuasively argnes that because fundamental values of nonsubordination and freedom from physical invasion are at stake, we inust strictly scrutinize disparities in treatment between

208. John Robertson takes this latter approach. See Robertson, supra note 7, at 354-55. Robertson suggests that the courts balance the risks and benefits of any proposed surgery. He notes, however, that the risks of organ donation make it unlikely that a court would order parental kidney donation to save a child's life. Id. at 355. Taken together, the risks, invasion, and pain attending a Cesarean make it much more comparable to organ donation than to less major imtrusions such as bone marrow donation.

209. Jay Katz and John Arras both emphasize this point. To the extent this Article inadequately reflects pregnancy's uniqueness, it is not because it is unrecognized. See Williams, The Equality Crisis: Some Reflections on Culture, Courts, and Feminism, 7 WOMEN's RTS. L. REP. 175, 195 (1982) ("The instinct to treat pregnancy as a special case is deeply imbedded in our culture, indeed in every culture. It seems natural, and right, to treat it that way.") (emphasis in original).

210. 42 U.S.C. $\$ 2000 \mathrm{e}(\mathrm{k})$ (1982).

211. See generally Erickson, Pregnancy Discrimination: An Analytic Approach, 7 WOMEN's RTS. L. REP. 11, $21 \&$ n.49 (1981) (thrust of the Pregnancy Discrimination Act is to require that pregnancy, childbirth, and other related medical conditions be treated as well as other nongenderspeciffc medical disabilities) (citing EEOC Guidelines, 29 C.F.R. § 1604.10(b) (1986)). This Act also calls into question certain "fetal protection" policies implemented by employers. See generally Williams, supra note 106 (challenging validity of employer rules excluding fertile and pregnant women from jobs that expose them to toxic substances).

212. Regan, supra note 96 , at 1623 . 
pregnant women and other potential Samaritans. ${ }^{213}$

To the extent that Regan's analysis provides an alternative justification for Roe, it too undermines the claim that no comparisons can be drawn to pregnancy. Moreover, whether or not one accepts Regan's Samaritan and equal protection argninents in the abortion context, the comparison between coinpulsory Cesareans and nonconsensual organ and bone inarrow "donation" is obvious, appropriate, and as close as any analogy to pregnancy can reasonably be. ${ }^{214}$ Recognizing that no analogy is perfect, if we caimot compare nonconsensual Cesareans to the closest analogues there are, then any equal protection scrutiny of differential treatment of pregnant women is impossible. It seems far better to consider other cases, while recognizing the limitations of such an approach. And, once other situations are considered, the enormous disparity between compulsory major surgery in this domain and the rejection everywhere else of far lesser intrusions strongly suggests that these unparalleled burdens that pregnant women are forced to bear constitute invidious discrimination, despite the state's benevolent motive.

Alternatively, one might take John Robertson's position and hold that parents, inale and female alike, should have far-reaching duties to rescue their children, including donating bone marrow and undergoing surgical procedures equally invasive and risky as Cesarean sections. ${ }^{215}$ This formulation makes the Cesarean cases not sui generis, but simply in the vanguard of the societal moveinent to inandate that parents be "Splendid Samaritans"; that is, that they assume obligations toward their children far greater than those assuined by the rest of society. Then the law would not, in theory, be treating pregnant women differently from parents in general; rather, pregnant woinen would simply be more frequently called upon to serve in their Samaritan capacity because of their peculiar biological relation to their unborn children. Robertson's position has the advantage of recognizing the equal protection probleins with mandating Cesareans but not similar rescues. It fails, however, to eliminate these probleins.

The reason it fails is simple: equal protection violations are not reinedied by constructing a rare (or hypothetical) case where soineone who is not a meinber of the discriminated-against class will suffer the saine burdens. For exainple, mandatory exclusion of persons with the sickle cell gene from certain kinds of einployment would not be rendered constitutionally acceptable even if it were shown that $.01 \%$ of whites have the

213. Id. at 1630. Regan also notes the importance of the history of discrimination against women. Id. at 1632 .

214. See id. at 1623-24, 1637-39 (refuting potential objection that comparisons of pregnant women to other types of Samaritans are "too far afield" for the judiciary to undertake).

215. See supra note 208 and accompanying text. 
sickle cell trait, so that the burden of the restriction would not fall solely on blacks but merely disproportionately on them. ${ }^{216}$ Realistically, there will be very few instances where fathers (or even nonpregnant mothers) will be affected by a theoretically even-handed rule that all parents must submit to surgery when necessary to aid their children. In fact, there will be so few occasions, in comparison to the number of women told they need a Cesarean, that the theoretical even-handedness will serve to highlight rather than eliminate the equal protection problem: it will show just how unlikely it is for anyone else to suffer the burdens imposed on pregnant women. Thus, theoretical consistency calmot mask inequity in practice.

Equal protection requires that the law not deny the reality of biological differences. ${ }^{217}$ Rather, we must recognize that imposing theoretically similar burdens will not yield substantive equality if those burdens are merely hypothetical or, at best, extreinely rare. Hence, the equal protection problem in mandating Cesareans remains both intractable and fatal to the validity of such intrusions.

\section{IV}

\section{ANSWERS FROM ABORTION LAW}

We have seen that state intervention to protect the unborn should not exceed state intervention to protect the already born. We also noted briefly that the fact that states can prohibit abortion after viability does not mean that they can mandate surgical intrusion upon the woman after that time. A further examination of abortion law will conclusively show that forced Cesarean dehvery violates the basic principles underlying Roe v. Wade.

Although Roe holds that even postviability abortions must be permitted if necessary to protect the woman's hife or health, ${ }^{218}$ few courts and coinmentators have recognized the significance of the holding for the Cesarean conflict. ${ }^{219}$ This holding means that at no time during pregnancy may doctors be required to place the welfare of the fetus above the

216. See L. TRIBE, supra note $159, \S 16-27$, at 1074. One quarter of $1 \%(.25 \%)$ of American blacks have sickle cell disease, and $8 \%$ of American blacks are asymptomatic carriers of the trait. $\mathrm{J}$. Thompson \& M. Thompson, Genetics in Medicine 101 (3d ed. 1980).

217. As Laurence Tribe puts it, "[A] stubborn inattention to the facts of . . . sex when they are relevant ... may be almost as pernicious if unintended a form of . . sexism as a deliberate attention to ... sex when [it is not] relevant at all." L. TRIBE, supra note $159, \S 16-27$ at 1073-74. For an interesting discussion of the importance of taking biological differences into account in equal protection analysis, see Law, Rethinking Sex and the Constitution, 132 U. PA. L. REV. 955, 1007-13 (1984).

218. 410 U.S. at 163-64.

219. One group of writers does consider it, however, and comes to the same conclusion reached in this Article. See Nelson, Buggy \& Weil, supra note 108, at 739-45 (requirement that women's health must prevail renders mandatory Cesareans unconstitutional under the abortion cases). 
woman's health. "Health" in this context has its ordinary meaning, rather than an artificially narrow one that considers only substantial threats of bodily harm. In Doe v. Bolton, for instance, the Court took note of the psychological as well as the physical components of health. ${ }^{220}$ Other cases have also emphasized that health includes a range of factors. ${ }^{221}$ Thus, unless she chooses otherwise, the woman's health, broadly interpreted, comes first.

It is clear that third trimester abortions inust be permitted even if the threat to the woman's health is not a grave one. State statutes have been invalidated for restricting postviability abortions to cases where the woman's health would be permanently impaired, ${ }^{222}$ or where she faced an "imminent peril" that "substantially endangers" her life or health. ${ }^{223}$ Even though postviability abortions may cause fetal death, states cannot require that the degree of threat and harm to the woman equal or exceed that to the fetus. Ratlier, once tliere is a legitimate threat to the woman, her health simply trumps the state interest in fetal survival.

Regulations concerning postviability abortion procedures must also recognize the primacy of the woman's health. When two abortion techmiques are equally safe for the woman, the state can constitutionally require that physicians use the one least harmful to the fetus. ${ }^{224}$ Nevertheless, the state cannot require that the inost benign fetal technique be used if this could potentially impair the woman's health. This was illustrated in Colautti v. Franklin, ${ }^{225}$ in which the Supreme Court invalidated a Pennsylvania statute requiring that after viabihty doctors use the inethod least likely to harm the fetus unless an alternative was "necessary ... to preserve the [woman's] life or health."226 The Court held that by using the word "necessary," Pennsylvania impermissibly implied that a different technique must be indispensable for the woman's health. This flaw was componnded by the failure to "clearly specify ... that the woinan's life and health must always prevail over the fetus's life and healtlı when they conflict."227 Hence, the statute unconstitutionally sug-

220. 410 U.S. 179,192 (1973).

221. See, eg., United States v. Vuitch, 402 U.S. 62, 72 (1971); see also Colautti v. Franklin, 439 U.S. 379, 400 (1979) (noting that statute being held unconstitutional failed to specify that "all factors relevant to the welfare of the woman may be taken into account").

222. Margaret S. v. Edwards, 488 F. Supp. 181, 196 (E.D. La. 1980).

223. Schulte v. Douglas, 567 F. Supp. 522, 525 (D. Neb. 1981), aff'd sub nom. Women's Servs., P.C. v. Douglas, 710 F.2d 465 (8th Cir. 1983).

224. The constitutionality of such a provision, contained in MO. REV. STAT. $\$ 188.030 .2$ (1986), was upheld by the Eighth Circuit in Planned Parenthood Ass'n v. Ashcroft, 655 F.2d 848, 862-63 (8th Cir. 1981), aff'd in part, rev'd in part, 462 U.S. 476 (1983), and was not challenged on appeal. 462 U.S. at 483.

225. 439 U.S. 379 (1979).

226. Id. at 400 (emphasis in original).

227. Id. 
gested that physicians could be required to make "trade-offs" between the woman's health and "additional percentage points of fetal survival."228 Other cases have reiterated that any conflict between the woman's health and the potential life of the fetus must be resolved in the woman's favor. ${ }^{229}$

These cases leave no doubt that a state could not statutorily select hysterotomy, a surgical procedure similar to a Cesarean section, ${ }^{230}$ as the method of choice after viability. Hysterotomy is the techmique that is best for the fetus; it is also much more hazardous for the woman. ${ }^{231}$ Significantly, it also appears that under Colautti a state could not require the use of the least feticidal technique even if it is not as disproportionately hazardous to the woman as hysterotomy. Some doctors had interpreted the Pennsylvania statute as requiring that prostaglandin rather than saline amnioinfusion be used in postviability abortions ${ }^{232}$ because prostaglandin is far more compatible with he birth than saline. ${ }^{233}$ Though prostaglandim is about as safe for women as saline, ${ }^{234}$ the Court refused to uphold the statute, noting that prostaglandin has certain contramdications and undesirable side effects. ${ }^{235}$ The Court's focus on inedical judgment, even im cases im which two techniques are roughly coinparable, deinonstrates that the best interests of the woman are paramount, even when promoting thein is detrimental to the fetus.

Thus, a fundamental principle of abortion law is that states cannot

228. Id.

229. See Thornburgh v. American College of Obstetricians, 106 S. Ct. 2169, 2182-83 (1986) (invalidating statutory requirement that postviability abortion method most likely to resuit in live birth be used unless it would pose "significantly greater" risk to the mother, and noting that a statute is unconstitutional if it requires the mother to bear any increased risk in order to save the fetus); $c f$. Planned Parenthood Ass'n v. Ashcroft, 462 U.S. 476, 485 n.8 (1983) (Powell, J., joined by Burger, C.J.) (interpreting statutory requirement of second physician's presence at postviability abortion to inciude an exception for emergency situations where delay caused by waiting for a second physician's arrival could endanger the woman's health). In Ashcroft, the four Justices who would have invalidated the second-physician requirement discussed more explicitly the mandate that the woman's hcalth must always prevail over that of the fetus whenever they conflict. See 462 U.S. at 501-03 (Blackmun, J., concurring in part and dissenting in part).

230. For a description of hysterotomy and other late abortion methods, see J. PRITCHARD, P. MacDonald \& N. GANT, Williams OBsTETrics 482-83 (17th ed. 1985) [hereinafter Williams OBSTETRICS].

231. The Court in Colautti noted that hysterotomy has the highest incidence of fetal survival of any abortion technique. 439 U.S. at 398 . Some doctors believed the Pennsylvania statute required hysterotomies after viability. Id. The Court also noted, however, that hysterotomy entails the risks that accompany anesthesia and an incision for the woman. Id. at 398-99.

232. Id. at 398 .

233. Id. at 399. Prostaglandin is about 40 times more likely than saline to result in live birth. Cates \& Grimes, Morbidity and Mortality, in Second Trimester ABortions 163, 171 (G. Berger, W. Brenner \& L. Keith eds. 1981).

234. See Bygdeman, Prostaglandin Procedures, in Second Trimester Abortions, supra note 233, at 89, 101-02; Cates \& Grimes, supra note 233, at 169-71.

235. 439 U.S. at 399. 
require trade-offs between the woman's health and the fetus's well-being. This principle becomes applicable to the Cesarean dilemma when we recognize that once the fetus is viable, abortion methods merge witl methods of inducing labor. ${ }^{236}$ In those rare cases in whicl an advanced pregnancy threatens the woman's healtli, pliysicians ordinarily advise a preinature delivery, a procedure that puts tlie fetus at risk but lacks the connotation of intentional fetal destruction that abortion carries with it. $^{237}$ If state-nnposed trade-offs are unconstitutional for late abortions, they must be unconstitutional for deliveries as well. Tlius, a statute could not require Cesarean delivery in cases in which there was some indication-fetal preinaturity, for example ${ }^{238}$ - that this procedure would be better for the fetus.

Doctors, however, are unlikely to seek court orders for surgery when there is only some indication that surgery would be preferable. Ratlier, a court-ordered Cesarean is likely to be requested only when the medical evidence strongly suggests that the fetus will otherwise be devastatingly impaired and tlee woman has no significant contraindication to surgery. Could a state statute constitutionally authorize nonconsensual Cesarean delivery in these cases? Given the congruence between postviability abortions and imduction of labor, this liypothetical statute would apply in both contexts. It would, lowever, be unconstitutional under abortion law as set fortl in Roe and Colautti. A surgical delivery, even in the absence of specific maternal contraindications, is more hazardous for the woman. ${ }^{239}$ Most woinen gladly run this risk to ensure the lealtli of their baby. In so doing, they are voluntarily making a trade-off between their safety and their child's. But Roe and Colautti demonstrate that these trade-offs cannot be compelled. True, the hypothetical statute would compel them only when the risk to the woinan froin surgery was

236. Dilatation and evacuation (D\&E), an abortion method in which live birth is impossible, cannot be done safely this late in pregnancy. See Williams OBSTETRICs, supra note 230, at 479 (recommending performing D\&E before about 16 weeks). Some doctors perform it later than this but not after 24 weeks. See Grimes, Second-Trimester Abortion in the United States, 16 FAM. PLAN. PERSP. 260, 264 (1984). Apart from D\&E, late abortion methods include induction of labor with substances such as prostaglandin or oxytocin, WILLIAMS OBSTETRICS, supra note 230 , at 482 , procedures likewise used to induce labor when a live birth is desired (especially oxytocin), and hysterotomy, a procedure similar to a Cesarean. Id.

237. According to Dr. Kenneth Ryan, before Roe's use of the term "abortion" in the context of the third trimester, doctors would never have considered a medical decision to terminate a pregnancy at this stage to be an abortion. Rather, it would have been considered a premature delivery (albeit a very risky one). Statement of Dr. Ryan, Chairman, Department of Obstetrics and Gynecology, Harvard Medical School, at Hastings Center Conference on Abortion and Scientific Change, May 23, 1985; cf. Tribe, The Supreme Court, 1972 Term-Foreword: Toward a Model of Roles in the Due Process of Life and Law, 87 HARv. L. REv. 1, 4 n.24 (1973) (after viability, maternal risks from removal of the fetus are ordinarily the same whether it is saved or destroyed).

238. "In general, the more immature the fetus, the greater the risks from labor and delivery." WILLIAMS OBSTETRICS, supra note 230, at 756.

239. For the risks of Cesarean delivery, see supra text accompanying notes 45-52. 
no greater than average; that is, it would require only the most justifiable of trade-offs. But statistical disparities in mortality and inorbidity between surgical and vaginal dehivery are no less real than individual inaternal contraindications to surgery. Hence, this statute would require trade-offs contrary to abortion law's mandate that the woman be allowed to place her health first and foremost.

Of course, one difference between the abortion regulations imvalidated in Colautti and court-ordered Cesareans is that the former restricted physicians' judgment and practice, while the latter implement doctors' recommendations. In the abortion cases, the Supreme Court has consistently deferred to medical judgment. ${ }^{240}$ But these respected judgments have concerned medical matters like the safety of abortion or of particular abortion procedures which, while sometimes in dispute, are factual judgments. There is no reason to think the Court would likewise defer to physicians' nonmedical beliefs that a woman should undergo increased risk for the sake of her child. Indeed, in this area the medical facts are indisputable-surgical delivery is more hazardous for the woman than vagimal delivery (except in those few cases where the woman's life is threatened by vaginal dehivery as well)-and the imposition of this increased risk could not constitutionally be required by any legislature. It is natural for obstetricians, who are heavily invested in obtaining optimal fetal outcome, to believe that severe fetal distress amply warrants subjecting the woinan to the shightly increased hazards of surgical dehivery. The overwhelming majority of pregnant women agree. But the state cannot constitutionally impose trade-offs between mother and fetus merely because doctors now desire those trade-offs.

Hence the only difference between a postviability abortion regulation requiring hysterotomy when the fetus would be harmed by vaginal dehvery-a clearly unconstitutional regulation-and a court-ordered Cesarean is the constitutionally irrelevant one that the pliysician is seeking the latter intrusion but probably opposing the former. Of course, the former is a statutory imposition while the latter is a court order in an individual and highly compelling case. But courts should not issue orders in individual cases that would be unconstitutional if generalized in the form of a statute, ${ }^{241}$ and einergency situations do not suffice to render subordmation of woman to fetus constitutionally acceptable. Given our prior exainination of "Good Samaritan" law, it is no accident that the

240. While the privacy right that encompasses the abortion decision is unquestionably the woman's, see Roe, 410 U.S. at 154, the Court stated that during the first trimester, "the attending physician, in consultation with his patient, is free to determine, without regulation by the State, that ... the patient's pregnancy should be terminated." Id. at 163 .

241. See generally, L. TR1BE, supra note 159, § 16-17, at 1025 (noting that equal protection mandate covers discriminatory legislation and adjudication, as well as executive and administrative behavior). 
Supreme Court forbids, even in late pregnancy, state imposition of maternal/fetal trade-offs. ${ }^{242}$ This lesson from abortion law must not be forgotten in the crisis-oriented setting of a refusal of a Cesarean.

\section{$\mathrm{V}$}

\section{Why Should LAW Allow THese Tragedies?}

We have seen that legal principles support respecting maternal refusals of surgery. This is an extraordinarily complex and troubling area, however. It surely merits something beyond narrowly legal analysis. A taxonomy of women's moral obligations to the developing fetus is far beyond this Article's scope. Yet, I suspect that most people would find a woman who refused a Cesarean for a frivolous reason such as abhoring abdominal scars to be acting in an inmoral manner. They might wonder what is wrong with judicial imtervention to prevent the tragic consequences of her reprehensible conduct. After all, pregnancy is unique, and the woman in labor is uniquely able to prevent irreparable harm to a vulnerable being by undergoing a quite routine surgical procedure. In these unusual cases, why should not a court hold that the principles of autonomy, nonsubordination, and bodily integrity exemplified in the law of treatment refusal, rescue, and abortion are weighty, but are not weighty enough to justify the predicted harm?

There are broad societal grounds that favor paying this tragic price for maternal freedom. First, court-ordered Cesareans may start us down that "shippery slope" toward controlling and coercing pregnant women in the name of fetal well-being. In addition, as Part VI explores at length, physicians may be overly alarmist in their predictions, causing judges to order unnecessary surgery. But let us hold both "slippery slope" fears and medical realities in abeyance a bit longer. Assuming that medical predictions are accurate, and that at least some maternal refusals may evoke justifiable moral condemnation, can we argue, at the level of ethical or legal theory, that upholding maternal refusals is the best general policy?

In this Part, I argue that despite the strong impulse to save the baby in an individual case, courts that respond to this temptation behave far more problematically than those that resist. My argument seeks to make explicit what is implicit in the McFall holding: that in some cases it is wrong for courts to pursue admittedly better consequences because this pursuit involves such significant invasions of individual rights and autonomy that they compromise the integrity of the court and the humanity of those subject to its rulings. In other words, I suggest that in these cases,

242. The reluctance to impose health risks also underlies Roe's statement that in the first trimester there is no compelling interest in regulating abortion because until about the 12th week abortion is safer for the woman than childbirth. 410 U.S. at 163. 
courts should not decide on the basis of consequences, but rather upon the primacy of individual rights and upon principles that limit the way in which a person (or state) may legitimately treat another.

My argument inevitably has its limitations. These cases are true dileminas, pitting certain of our most fundamental intuitions against one another. I do not show that upholding refusals is morally unproblematic-no solution here will be ideal. Nor will this argument convince thoroughgoing consequentialists (although my discussion of the potential societal consequences of maternal coercion in Part VI may persuade soine), because it is premised upon the idea that there are fundamental and unresolvable problems in judicial miplementation of a predominantly consequentialist ethic. Nevertheless, my argument will at least slow that tlie problems inherent in elevating consequences above rights are extremely serious, and that courts violate our fundamental ethical intuitions and societal precepts wlien they intervene to compel one individual to assume risks for tlie sake of anotlier.

\section{A. The Perils of Judicial Consequentialism}

\section{Wronging Women by Treating Them as Means}

A consequentialist ethical theory views the ethically "right" action as the one that produces the best consequences. ${ }^{243}$ Because consequences can be evaluated in numerous ways, there are many complexities and controversies within consequentalist ethics. For example, there is debate as to whether the evaluation should focus on the consequences of an individual act (act-consequentialism) or on the societal consequences of having a rule of which the act is an instance (rule-consequentialism). ${ }^{244}$ Nevertlieless, all versions of consequentialism focus on the impact of an action, ratler than on something imtrinsic to tle act, such as the actor's motivation or the act's conformity with a moral rule.

A standard objection to consequentialisin is that some actions that we feel are wrong would be morally permissible if they yielded an overall balance of good consequences. If punishinent of an innocent person would save many other people, or would reduce crime, or would otherwise yield the best consequences, it would appear to be inorally justi-

243. Williams, $A$ Critique of Utilitarianism, in UTILITARIANISM: FOR AND AGAINST 77, 85-86 (1973).

244. Because this debate often occurs among utilitarians, who evaluate consequences according to whether they produce the most societal happiness or good, the more common terms are act- and rule-utilitarianism. See id. at 81 (discussing this distinction, though usiug the terms "direct utilitarianism" for an evaluation that focuses upon the consequences of a particular act, and "indirect utilitarianism" for an evaluation that focuses on the consequences of societal rules or practices). See generally Rawls, Two Concepts of Rules, 64 PHIL. Rev. 3 (1955) (distinguishing actand rule-utilitarianism). 
fied. ${ }^{245}$ Likewise, if five dying patients all needed organ transplants and could all be saved by a surgeon reinoving, without permission, the relevant organs from a healthy young patient who had just come in for a physical, a consequentialist ethic would treat this as a serious option, inasinuch as one dead is surely better than five dead. ${ }^{246}$ Of course, a consequentialist could reject actions of this sort on the ground that they inevitably create bad consequences overall by threatening social stability or by destroying trust in physicians, among other reasons. But even if a consequentialist can ultimately reach the commion sense conclusion that punishment or sacrifice of one person for the good of others is immoral, consequentialism is still open to the objection that it does not take seriously a set of important and intuitively felt moral precepts about how one individual should and should not treat another.

These precepts are the prescriptions of a nonconsequentialist or, more specifically, deontological ethic, as best exemplified by Kant. As Kant formulated his moral rule, or categorical imperative: "Act in such a way that you always treat humanity, whether in your own person or in the person of any other, never simply as a means, but always at the same time as an end." ${ }^{247}$ The Kantian emphasis on how we treat other people, whatever the consequences, is necessary if we are to fully respect others. As Charles Fried, an exponent of a strongly deontological ethic, suggests, "What we may not do to each other, the things which are wrong, are precisely those forms of personal interaction which deny to our victim the status of a freely choosing, rationally valuing, specially efficacious person, the special status of moral personality."248 Punishing or sacrificing one to save many is wrong because, as Fried continues, "If we use harming another as the means to our end, then we assert that another person niay indeed be our means . . . ."249

245. See McCloskey, A Non-Utilitarian Approach to Punishment, in PhILosophical Perspectives on Punishment 119, 123-26 (G. Ezorsky ed. 1972) (criticizing consequentialistic view that even "grave injustice" against innocents is demanded if it serves "the greatest good.") McCloskey relies on one of the classic formulations of this critique of utilitarianism, W.D. Ross, THE RIGHT AND THE GOOD 56 (1930). For an attempted defense of utilitarianism against this sort of attack, see Sprigge, $A$ Utilitarian Reply to Dr. McCloskey, in PhilosophiCal Perspectives on PUnIShment, supra, at 66; see also Rawls, supra note 244, at 24-30 (rule or generalized institution for punishing the innocent could not plausibly lead to the greatest good for society).

246. This sort of example is discussed at length in Thomson, The Trolley Problem, 94 Y ALE L.J. 1395 (1985). Although Thomson is not specifieally engaged in a critique of consequentialism, her explanation of what is wrong with such conduct emphasizes rights and the importance of one person's taking the action or setting in motion the instrumentality that harms another. See id. at 1406-15.

247. I. Kant, Groundwork of the Metaphysic of MORals 96 (H.J. Paton trans. 1964) (emphasis in original). For a discussion of Kantian theory's focus on autonomy, rights, and treating persons as ends in themselves, sec J. Murphy \& J. Coleman, The Philosophy of LAw: AN INTRODUCTION TO JURISPRUDENCE 78-86 (1984).

248. C. FRIED, RIGHT AND WRONG 29 (1978).

249. Id. (emphasis in original). 
The principle that people should not be used merely as means, even to promote the best of ends, applies not only when serious pliysical harms would be imposed, but also when one is contemplating violating an individual's riglits or treating him badly in a more minor way. In illustrating the ethical force of deontological reasons, Thomas Nagel formulates an example in which a less significant type of liarm is contemplated:

You have an auto accident one winter night on a lonely road. The other passengers are badly nijured, the car is out of commission, and the road is deserted, so you run along it till you find an isolated house. The house turns out to be occupied by an old woinan who is looking after her sniall grandchild. There is no phone, but there is a car in the garage, and you ask desperately to borrow it and explain the situation. She doesn't believe you. Terrified by your desperation, she runs upstairs and locks herself in the bathroon, leaving you alone with the child. You pound ineffectively on the door and search without success for the car keys. Then it occurs to you that she might be persuaded to tell you where they are if you were to twist the child's arm outside the bathroon door. Should you do it? 250 $^{250}$

Nagel then states:

It is difficult not to see this as a serious dileninia, even though the child's getting his arm twisted is a minor evil compared with your friends' not getting to a hospital. The dilemma nust be due to a special reason against doing such a thing. Otherwise, it would be obvious that you should choose the lesser evil, and twist the child's arm. ${ }^{251}$

Deontological reasons focus on persons, and on liuman interaction, ratlier than solely on consequences. Altliough the consequences will unquestionably be better if you twist the child's arm, the problem, for a deontologist, is that you can achieve the good consequences only by wronging the child. As Nagel puts it, "Deontological reasons liave their full force against your doing something-not just against its happening."252 Likewise, as he says about his liypothetical, "[T]hings would be better, what happened would be better, if I twisted tlie child's arm than if I did not. But I would have done something worse."253 The child will have been treated badly, and the driver will intentionally lave chosen to treat him in this way.

Thus, a consequentiahist approach to this dilemina, or to action in general, ignores two considerations that are central to morality: First, persons should not be treated in certain ways wliatever the consequences;

250. Nagel, The Limits of Objectivity, in I. The TANNER Lectures on Human Values 75, 126 (S. McMurrin ed. 1980).

251. Id. (emphasis in original).

252. Id. at 127 (emphasis in orginal).

253. Id. at 131 (emphasis in origianl). 
and second, how a state of affairs comes about-that is, whether I cause it or not-is morally relevant. Bernard Williams, a cogent critic of consequentiahism, says that for consequentialists, "all causal connexions are on the same level, and it makes no difference, so far as that goes, whether the causation of a given state of affairs lies through another agent or not."254 The problem with this causal nihilism is that it ignores the important value of individual imtegrity and the idea that each of us is specially responsible for what he or she does. ${ }^{255}$

A court that compels surgical dehivery will undoubtedly phrase its discussion in terms of the rights of the woman and the state interest in the fetus. It may not think it is basing its decision on consequences, rather than simply balancing the woman's rights against the fetus's rights, or the state's interest in it. Yet, in an important sense its orientation is consequentiahist; it is letting the dire consequences to the fetus "trump" the woinan's rights of privacy, autonomy, and bodily integrity. Significantly, in contrast to state impositions to promote a larger and very public interest-the draft, for example-Cesarean cases are unique in that the rights of one individual are subordinated to protect another individual. The judicial decision to mandate such subordination, rather than to respect the woman's refusal of it, exemplifies the consequentialist view that when the outcome of respectimg a right is very bad, the right can be overridden. The right-holder, then, is treated as a means to achieving the better consequences.

Just as the driver in Nagel's example will have wronged the child if he twists his arm, the court that orders a Cesarean will have wronged the woman. Indeed, it will have decided for her what medical risks she should run. This is a very significant, and presumptuous, step. The court can know what the risks of surgical delivery are, and their prevalence im a large population of women. But it can know neither the precise risk to the woman ${ }^{256}$ nor her subjective response to such risks. As the saying goes, "Minor surgery is surgery performed upon somebody else." Furthermore, the informed consent doctrine requires that individuals be able personally to weigh and assess the risks of inedical procedures. ${ }^{257}$ This is because third parties, no matter how concerned and knowledgeable, are relegated to objective decisionmaking and cannot take into account the crucial subjective factors. When a court orders Cesarean delivery, it derogates these subjective factors and fails to acknowledge that its vision, like any third party's, is clouded by objectivity.

254. Williams, supra note 243 , at 94 .

255. Id. at 99.

256. See infra note 268 .

257. See supra text accompanying notes 109-17. 
The court's inability to incorporate these crucial subjective factors into its decisionmaking is even more striking in cases in which the woman's refusal of surgery is based upon values that transcend views about bodily risk and pain. An objective third party who does not share another's deeply held behefs about rehgion or the "natural order" of things cannot possibly understand or assess the trauna caused by violation of such beliefs. ${ }^{258}$ Because an objective third party must weigh individual beliefs without beheving them, imposing an objective decision on the woman treats her, in a sense, as if she were not a unique individual entitled to make life choices according to her behiefs, even if unusual or idiosyncratic. If decisions are made for her that violate those beliefs, they suggest that these features of the wornan can be ignored or excised. But respect for others requires respecting their individuality. If decisions are made for a woman im a way that suggests that it does not matter very much who she is, then she has, in a very real sense, been wronged.

Of course, courts in these cases do not override women's choices lightly. They are faced with extraordinarily hard decisions in whicl the threat to the infant must be neither demied nor minimized. But, if the way to avert this threat is to coerce the woman and violate her riglits, then the court, in pursuing the best consequences, inevitably treats the woinan merely as a means to the goal of preserving the infant's liealth. As this Article shows, there are serious problems with a court's treating a person in this way.

\section{Factoring in Physical Harm}

Althougli it seeins indisputable that overriding the woman's refusal wrongs her, there is a serious objection to the strongly rights-based claim that it is never morally permissible to wrong another in this fashion. This objection is that just as a thoroughgoing consequentiahst may endorse massive invasions of rights to promote good consequences, an absolutist about rights may permit extraordinarily tragic consequences in order to avoid doing quite trivial wrongs. ${ }^{259}$ In other words, the thoroughgoing deontologist may preserve his "moral purity," but at an excessive cost. ${ }^{260}$ The standard example illustrating this objection is that of a

258. Even if a third party tries to factor in such reasons, this simply cannot be done from an objective standpoint. Nagel makes the important point that objective understanding of reasons specific to an individual "does not imply objective acceptance of them; because in order to have and act on them one must occupy the perspective of a particular life and its aims." Nagel, supra note 250 , at 123 (emphasis in original).

259. This is a standard objection to a strongly rights-based ethic. For one attempt to respond to it, see C. FRIED, supra note 248, at 10 (concept of the catastrophic is a distinct concept that identifies the extreme situations in which the usual concepts of right and wrong no longer apply). He suggests that there is also a corresponding category of trivial, or de minimis, wrongs in which absolute prohibitions similarly do not apply. Id.

260. Brian Barry makes this sort of a critique of Fried's absolutist deontological ethic. Barry 
murderer who comes to one's door asking the whereabouts of a man who is hiding inside. In such a case, a pure deontologist may be unable to justify lying to save the potential victim's life. ${ }^{261}$ Likewise, in Nagel's example, just as a pure consequentialist would find that twisting the child's arm obviously is the best course of action, without giving due weight to the deontological considerations against it, a pure deontologist would refuse even to consider twisting his arm, despite the impending death of the passengers. For that matter, he could not even justify a lesser wrong, such as falsely claiming to be a neighbor or a friend of a friend, in order to induce the grandmother to loan the car.

A proponent of this objection to a strict deontological ethic would argue that opposing court-ordered Cesareans because they violate the woman's rights gives too hittle weight to consequences so tragic that they can appropriately override even quite fundamental rights. After all, courts that order Cesareans are not espousing a thoroughgoing consequentiahism; they consider the woman's rights, but simply hold that in this unusual circumstance, such rights have to take second place to the fetus's interests and the state's interests im preserving and protecting potential life.

This objection to an uncompromising rights-based position is not without force. As violations of rights become increasingly minor and the consequences such violations could prevent approach the catastrophic, few but the true absolutists would insist that rights can never give way. ${ }^{262}$ But the claim that courts should not mandate major surgery to prevent

claims that Fried's emphasis on individual integrity, that is, on not doing wrong even if far worse things occur due to your inaction, leads to a form of moral narcissism, in which the only consideration is how your actions appear. Barry, And Who Is My Neighbor? (Book Review) 88 YALE L.J. 629, 645 (1979).

261. Fried deals with this example by arguing that lying to the murderer is justified because he has no right to the truth. In other words, lying to the murderer does not wrong him because it violates no right of his. This is unlike the case in which you must intentionally injure one person to help another. C. FrIED, supra note 248, at 69-74. Barry is critical of this view, stating that the point is not whether the proponent of the theory can reach the right conclusion with enough argument, but whether the theory as it is structured requires a great deal of fancy footwork to avoid reaching a thoroughly counterintuitive conclusion. Barry, supra note 260, at 645-46.

262. Fried's theory is particularly susccptible to this critique because he argues not only that individual rights should place stringent limits on what the state can force people to do, but that individual morality can likewise be described in these absolutist, rights-based terms. C. FrIED, supra note 248 , at 172 . Barry criticizes Fried for too readily shifting from legality to morality, stating:

Fried quite shrewdly assumes that the vision of people having their kidneys forcibly extracted is going to be abhorrent to most of his readers. But we can agree that it should not be legally required to give blood or contribute to the common good without agreeing that people should not feel bad about failing to do so.

Barry, supra note 260 , at 655 . I am not arguing that women necessarily act rightly when they refuse Cesareans, or that moral judgments about their conduct cannot be made. I argue only that the state acts wrongly when it overrides their choice. As one commentator has noted, "The immorality of imposing a sacrifice upon an individual is completely compatible with that individual's nonetheless being morally required to take the sacrifice upon himself." Kagan, Does Consequentialism Demand 
fetal harm is not, I will argue, an example of such counterintuitive moral absolutism. It might be difficult to defend absolute maternal autonomy if the issue were refusal of a completely harmless substance, such as a vitamin, that could save her fetus from irrevocable harm. Major surgery, however, does more than violate the woman's rights; it also subjects her to physical harm. Even if one rejects the notion that rights always and inevitably trump consequences, factoring physical harm into the moral equation yields the conclusion that at least those wrongs that entail harms are morally impermissible, whatever the consequences.

It is virtually a truism to say that the issue of court-ordered Cesareans could arise only within a medical system in which Cesareans had become safe and relatively routme. I suspect that few doctors would even consider seeking a court order if the recalcitrant woman faced unusually high surgical risks-for example, if she had a severe bleeding disorder or a family history of unexplained death or paralysis from anesthesia. Analyzing why surgery should not be imposed if there is a significant risk of serious maternal harm, albeit a lesser risk than the fetus would face in a vaginal dehivery, may help show why a proper appreciation of the import of harm suggests that even relatively safe major surgery should not be imposed.

Theories of moral and legal obligation uniformly recognize the fundamental fact that human beings tend to value their own hives above those of others, inaking it unrealistic to expect them to sacrifice themselves for other persons. Hence, using lethal force in self-defense is lawful, even if the attacker is himself innocent. A person under attack by several others can kill all of thein, even though the end result is the death of several persons rather than one. Objectively, this result is worse, but an individual is not expected to take an objective stance when his own life is threatened. Likewise, even im countries where rescue is required, no one is under a legal duty to risk his life im a rescue. This is simply too much to demand of a person, in light of the deeply imgrained human drive for self-preservation.

Needless to say, persons in the position of making decisions about others must respect the fact that an imdividual's life is, to him, invaluable. ${ }^{263}$ This is another reason why it would be unthinkable for a surgeon unilaterally to decide to distribute one person's organs to five other

Too Much? Recent Work on the Limits of Obligation, 13 PHIL. \& PUB. AFF. 239, 243 (1984) (emphasis in original).

263. In the early days of dialysis, a vexing question was how to decide which patients should receive this scarce and expensive life-saving procedure. Paul Ramsey, among many others, argued that random selection was preferable because "life is a value incommensurate with all others, and so not negotiable by bartering one man's worth against another's." Ramsey, A Human Lottery?, in ETHICAL IsSUes IN MODERN MEDICINE 468, 470 (J. Arras \& R. Hunt 2d ed. 1983). Indeed, the very idea of doctors or committees deciding which persons should live was so troubling to the 
patients who desperately need just those organs. The almost primal revulsion we feel at a person's or government's sacrificing one person to benefit others apphies to lesser bodily invasions as well. As Laurence Tribe states, "That one person's two good eyes, distributed to two blind neighbors, might yield a net increase in happiness on the theory that one blind person will experience less misery than two, cannot justify a governmental decision to compel the exchange."264 Were there a serious risk of the woman's suffering permanent harm from the surgery, requiring it would seem too much like these examples, where our intuitions strongly tell us that such decisions are ethically impermissible.

The intuition that it is impermissible to harm one person to aid another is derived from two closely related principles. The first is that any duty to help must be viewed as less weighty or stringent than a duty not to harm, such that if helping $A$ requires harming $B$, it is better that we forego helping $A .^{265}$ The second principle is that, contrary to the consequentialist's views, it is significant that $A$ 's injury will occur through natural forces or the malevolent act of a third person, but that the harm to $B$, if you choose to aid $A$, will be of your own doing. ${ }^{266}$ It is tragic that persons are harmed, but it is wrong that you harm them. These principles explain why physicians and courts would be so unlikely to impose surgery upon, for example, a woman who would be rendered sterile by it; it would be too clear that the fetus could not be rescued without harming her.

But how does all this apply to the typical Cesarean case, given the general safety of surgical delivery? First, we should note that there is at least a risk, albeit a small one, of lasting physical harm. The mortality rate for Cesareans is very low, approximately 4 in $10,000 .{ }^{267}$ For the individual woinan, however, there is no way to determine the precise risk of death imposed, because statistics apply to groups, not individuals. ${ }^{268}$ Nor can the court foresee the extent to which the risk might be increased

American populace that legislation was quickly passed to fund dialysis for all victims of end-stage renal failure. See Murray, Ethics and Health Care Allocation, 4 PUB. L. F. 41, $46-47$ (1984).

264. L. TRIBE, supra note 159, § 15-9, at 918.

265. For a strong defense of this principle, see Foot, The Problem of Abortion and the Doctrine of the Double Effect, in KILling AND LeTTING Die 156, 160-63 (B. Steinbock ed. 1980).

266. The importance of this distinction is stressed by C. FRIED, supra note 248, at 2, 73; Williams, supra note 243, at 99; and Thomson, supra note 246, at 1406-15.

267. CeSAREAN ChILDBIRTH, supra note 17, at 255. There is, however, a great deal of variation in rate. Id. at 255-60. Some sources list the mortality rate as approximately 1 per 1000 . Munsick, Comments to Haverkamp Study, 134 AM. J. OBSTET. \& GYNECOL. 409, 411 (1979).

268. The fact that the mortality rate of a procedure is $X$ in 1000 does not mean that the individual woman's chances are $X$ in 1000 , because statistics yield information about populations, not individuals. See W. HAYS, STATISTICS 24 (3d ed. 1981) (cannot extrapolate from fact that .50 is the relative frequency of an outcome $X$ given a large number of experiments to assign any probability to the chance of outcome $X$ 's materializing in an individual experiment); see also Albert, Decision Theory in Medicine, 56 Milbank Memorial Fund Q. 362, 369 (1978). 
by the fact that the surgery will often be done on an emergency basis ${ }^{269}$ and will be nonconsensual as well. ${ }^{270}$ Thus, the court necessarily imposes some small chance of death or permanent damage upon the woman. More importantly, if our society adopts a general pohicy of mandating Cesarean delivery when the fetus is imperiled, some women, albeit a very small number, will eventually be sacrificed in order to save some inucl larger number of babies. Thus, althougli the cliances of sacrifice in any individual case are very small, when we view compulsory Cesareans as a general policy, we see that it imposes the very trade-offs between maternal and fetal health that the Supreme Court disallowed in the abortion cases. Altliough the Court did not provide an ethical analysis of why trade-offs were impermissible, abortion doctrime reflects the view that a woinan should not be used without her consent as means to enhanced fetal healtli.

We need not, however, rely on the potential for deatli or lasting disability to hold that forced Cesarean delivery constitutes a harm. Returning to Nagel's example, someone who objected to a pure deontological ethic could readily feel that twisting the child's arm was justifiable because the wrong was de mimimus and the liarm it would prevent severe. But how about breaking his arm? If the distrauglit driver goes this far, lie will not only violate the boy's rights but will also cause him significant, though presumably not permanent, physical liarm. It is safe to say that most people, except for thorougligoing consequentialists, would feel this was going too far, because harming the boy to this degree, even in the pursuit of good consequences, transcends the bounds of moral perınissibility. The reason it does, of course, hearkens back to the principle that one sliould not breach the (stringent) duty not to harm im order to comply witl the (weaker) duty to do good.

Performing a Cesarean, I submit, imposes harm that is on the order of breaking the child's arm to benefit the passengers. Neitlier performing a Cesarean nor breaking an arm is likely to liave permanent consequences, but they both involve substantial pain, bodily invasion, and subsequent recovery time. Similarly, the $M c F a l l$ court's revulsion at imposing the (lesser) harm of bone marrow extraction can be explained by the unwillingness to treat a liuman being as a means to another's end,

269. Statistics often combine elective and emergency Cesareans, but the latter are more dangerous. Feldman \& Freiman, Prophylactic Cesarean Section at Term?, 312 NEw ENG. J. MED. 1264,1265 (1985).

270. Although there are no studies (and would probably never be sufficient patients for an adequate study) of the safety of nonconsensual Cesareans, given the increasing recognition of the impact of emotions on health, it would not be terribly surprising if women having surgery against their will experienced increased morbidity. For a discussion of emotional responses and their role in coping with medical problems, see generally Cohen \& Lazarus, Coping with the Stresses of Illness, in Health Psychology: A Handbook 217, 235-41 (G. Stone, F. Cohen \& N. Adler eds. 1979). 
especially when doing so entails physical harm. Just as the McFall court implied that its judicial integrity would be compromised by "sinking its teeth" into one citizen to aid another, courts ordering Cesareans compromise their integrity by plunging knives into unconsenting woinen. ${ }^{271}$

Of course, the court merely authorizes the surgery, it does not perform it. But this only obscures the violence lurking within the court order, violence that can be highlighted by practical realities. For example, what are the limits on force that may be imposed on women like Mrs. Jeffries and Mrs. Headley who refuse to return to the hospital? 272 Can the police be sent to get thein? Or, if a woman is present but resisting, can the doctors hold her down and forcibly anesthetize her? Concerned physicians inevitably raise these issues; they abhor the thought of doing violence to patients. ${ }^{273}$ These issues are much more than inere practical probleins in enforcement. Rather, they illustrate how, in a very real sense, the state is assaulting the wornan even though her compliance in the face of a court order may often obscure this. The court order muffles the disturbing overtones of violence because the court authorizes but does not act, while the doctor acts but can tell himself that the court has given a superior authorization. But even if, in our variant on Nagel's example, soineone else gave the driver permission to break the child's arm, or did the actual breaking at the driver's request, the moral responsibility for the broken arm would still be the driver's. Likewise, when the court authorizes nonconsensual surgery, it becomes responsible for the violence it is approving.

The court that orders surgery inay also be responsible for real harin. Suppose that the nonconsensual surgery is performed, and despite all due care by the doctors, the woinan dies or suffers irreparable injury. Absent neghigence, the physicians would not be legally liable, and of course the court would not be legally liable in any case. But, intuitively, the court seeins to bear moral responsibility here, just as the man in Nagel's example would be morally responsible if he twisted the cliild's arm and it broke. The court seems responsible because it imposed the risk and set in

271. For a similar conclusion, see Fletcher, supra note 5 , at 35 (coercion to protect fetus is morally self-defeating because it necessarily involves committing a moral wrong against the woman).

272. See In re Baby Jeffries, No. 14004, slip op. at 9 (Jackson County, Mich. P. Ct. May 24, 1982), authorizing the police to transport Mrs. Jeffries to the hospital against her will. See Detroit Free Press, June 13, 1982, at 3A, col. 4; Id. June 16, 1982, at 3A, col. 4 (Mrs. Jeffries goes into hiding and then gives birth vaginally at another hospital); Shulman Interview, supra note 29 (Ira Headley has vaginal birth at home).

273. Some doctors who favor obtaining a court order state that they would not use physical force to perform the surgery. Statement of Dr. Norman Fost, Presentation on Fetal Therapy at the Hastings Center, Conference on Abortion and Scientific Change Hastings-on-Hudson, New York (May 24, 1985). Others consider the problem of potential need for force as a strong reason to oppose seeking authorization for nonconsensual surgery. Shulman Interview, supra note 29; Cohen Interview, supra note 125 . 
motion the harmful series of events, that is, the nonconsensual surgery. The court is heavily involved when it imposes surgery; it takes on responsibihty for rescumg the fetus and must therefore be responsible if the woman is ever harmed seriously or even less substantially.

It might be objected that if the court does not order surgery it sacrifices the fetus and will bear responsibility for this. Imitially, a decision not to order surgery may appear this way. But the degree of state responsibility is very different when the court orders surgery and when it does not. Because individuals ordmarily make their own medical choices and assume moral responsibility for them, the woman who refuses surgery despite predictions of harm to her baby inay be morally to blame if such a result materializes. It may be appropriate to say that, morally speaking, if surgery could have prevented the harm, its occurrence is the woman's responsibility. But the state is not ordinarily so involved. Ouly if the state overrides the woman's choice does it become a sufficiently active participant to acquire moral responsibility for the outcome. Surely the driver in our variant of Nagel's example would not be responsible for the passengers' deaths if he failed to break the child's arm to secure the car. No duty to rescue could encompass inflicting such harm. Similarly, it is unlikely that the state has a duty to rescue when doing so requires imposing major surgery upon an unwilling citizen. Therefore, the state is not responsible for the consequences, however tragic, to the fetus, in the same way that it will be responsible for any harm that befalls a woman whom it coerces to have surgery.

\section{B. Problems with a Paternalistic Justification}

Thus far, we have spoken as if the Cesarean is being performed only for the sake of the child. In several senses, however, it inay be said to be in the woman's best interests as well. In cases such as Jefferson and Jeffries, the woinan has a condition that makes vaginal dehivery unsafe for her also. If she is likely to die from vaginal dehvery then it caumot be said that the state is imposing an additional physical risk upon her for the sake of her child. Indeed, in these cases some physicians may view the presence of the viable fetus as essentially a justification for preventing the death of a young and otherwise healthy woman.

Undoubtedly, the impulse to override a refusal is even stronger when the woinan's refusal will probably kill her along with her baby. In light of patients' general right to refuse treatment, acting on this impulse treats the pregnant woman's refusal very differently from other competent patients' refusals of life-saving therapy. Inasmuch as young, healthy Jehovah's Witnesses can refuse blood transfusions (at least they may if childless), the discrepancy must be based on the fetus's, rather than the woman's, interests. This raises all the problems with using the woman as 
a means to save her child; though her life may be saved, she is harmedaccordimg to her behiefs-by being denied everlasting life.

Even if the woman's life is not in danger, a paternalistic justification for compelled surgery can still be attempted. If the woman's refusal is upheld, and the child is devastatimgly impaired, the woman may well feel that had she really comprehended the enormity of her act, she would have acceded to the doctors' demands. ${ }^{274}$ Alternatively stated, if her refusal is overridden and her child is healthy, she will very likely thank the doctors afterward and perhaps even feel that if she had fully grasped the gravity of the situation at the time, she would not have refused so adamantly. Because parents naturally want a healthy child and suffer if their child suffers, a paternahistic justification for state intervention might claim that although the court overrides the woman's expressed wishes, it implements her real wishes by saving her from becoming the parent of a severely impaired child.

This justification for mtervention appears to avoid the inappropriate subordination of the woman's health to her baby's health. Indeed, it appears to focus on the imterests of the woman. As such, it would not apply to the woman who firmly believes that accepting God's will (or lettmg nature take its course) is more important than ensuring normalcy in her child. Nor would it apply to the woman whose culture is tolerant of having a handicapped child but brands surgical delivery as a failure on the woman's part. ${ }^{275}$ The paternahistic justification would be limited to cases in which the woman's values were substantially similar to the doctor's, but her actions were likely to thwart, rather than promote, those values.

Of course, if for some reason the woman lacks the capacity to understand the dilemina or to choose competently, the paternalistic theory is unnecessary. In these rare cases, a proxy decisionmaker is necessary, and that decisionmaker (be it a husband, parent, guardian, or judge) can legitimately decide on the woman's behalf. This decision could be based either upon the woman's best imterests or upon her probable preference were she competent. ${ }^{276}$ Either of these standards may support the choice of surgery as long as the best-imterests analysis considers the woman's mterest in having a normal child as well as the maternal safety of the

274. John Arras has suggested this justification to me.

275. Dr. Wayne Cohen has described how some patients from Jamaica, Haiti, and Africa are members of cultures that place a terrible social stigma upon Cesarcan delivery. Cohen Intervicw, supra note 125.

276. The best interests and the substituted judgment test are the two standards commonly uscd for proxy decisionmaking. See PREsIDENT's COMMISSION FOR THE STUDY OF ETHICAL ProblemS in Medicine and Biomedical and Behavioral Research, Deciding to Forego LifeSUSTAINING TREATMENT 132-35 (1983). 
various modes of delivery. Thus, surgery could be ordered in these cases even though competent women's choices are always honored.

The paternalistic approach does, however, apply to cases in between the extremes of the woman who makes a religious choice and the one who is too mcapacitated to clioose. When a woman refuses surgery out of groundless fear or refusal to accept the import of ominous fetal heart tracings, there is good reason to believe that, althougli she is legally competent, slee is denying the reality of her situation. ${ }^{277}$ The paternalistic theory would allow courts to recognize this reahty for her, choosing as they think she would choose were she psycliologically able to accept the imminent and substantial nature of her baby's peril, or at least choosing in a way they beheve she will be grateful for later.

Unfortunately, there is a serious problem with paternalism: its scope knows few bounds. Along witl their religious precepts, some Jeliovah's Witnesses may liarbor the behief that they will hive even witl1out a transfusion. ${ }^{278}$ Likewise, cancer patients who forego chemotherapy or women who choose a "lumpectomy" despite their doctor's recommendation of a total mastectomy may supplement their desire to avoid the pain of chemotherapy or the mutilation of mastectomy witl the belief that they will survive witlout the recommended treatment. If they are wrong, one may say im retrospect that their values would have been better impleinented liad thieir unorthodox clioices been overridden. In otlier words, a focus on probable consequences may frequently justify overriding eccentric choices, when those clioices combine unusual values with a seeming denial of medical probabilities. If ouly pregnant women's choices are overridden, then the true basis for this action seems not so much the woman's "real will" as the fetus's best interests-a ground we have seen to be an ultimately insufficient justification for wronging the woman. If, for the sake of consistency, other persons' choices are overridden as well, we might as well abandon the doctrine of informed consent entirely and embrace instead a new notion of "inforined acquiescence." The unacceptable nature of eitlier of these alternatives suggests that the notion that the state can recognize and implement a competent person's "real will" sliould be rejected, despite its appeal in these obstetric dilemmas. ${ }^{279}$

The danger in letting courts impose wliat is, im effect, a prospective

277. Doctors inclined to uphold competent refusals often state that they find these sorts of refusals the most difficult to deal with and to uphold. Cohen Interview, supra note 125 . These women, however, are likewise the most susceptible to persuasion. Id.

278. Indeed, sometimes they are right. In In re Osborne, 294 A.2d 372 (D.C. 1972), Mr. Osborne survived even though his refusal of blood was upheld. 294 A.2d 372, 376, n.6 (D.C. 1972).

279. Rejection of state imposed paternalism is, of course, completely consistent with physicians', nurses', and social workers' using all other means of persuasion to overcome the seemingly ill-founded resistance in these women. 
"reasonable person" standard on intimate personal decisions about life and health is underscored if we consider how a future court could respond when a woinan chooses to continue to carry a severely defective fetus to term. Almost every woman who learns that her fetus has a serious anoinaly aborts. ${ }^{280} \mathrm{~A}$ few women may not, however, either for religious reasons or for the more troubling reason that they deny the reality or severity of the diagnosis. What if, in the latter case, a physician brought suit to coinpel an abortion for an extremely severe defect, arguing that the woman's refusal reflected massive denial, that forcing the child to endure such a brief and painful life would be tantamount to torture, and that the woman would be grateful when she coines to her senses? ${ }^{281}$ In our society, nonconsensual abortion justified by reference to the woman's "real will" is unthinkable. ${ }^{282}$ But this may well be an historical or cultural accident, based on the rather unusual congruence of right-to-life and civil libertarian concerns. Even if courts would not go this far, allowing courts to override unusual choices by pregnant women, whether to benefit the child or to implement the woman's "real will," has unbridled potential for state usurpation of individual choice.

\section{Can the State Opt Out Altogether?}

It has been suggested that one way to avoid state coercion in these situations, yet still to reflect their extraordinary moral complexity, is for courts to refuse to decide them. ${ }^{283}$ By refusing to decide such cases prospectively, courts would return the moral burden of these dilemmas to the parties involved. Doctors either would have to honor their patient's choice or, if they felt an overriding moral obligation to the viable fetus, to perform unconsented-to surgery knowing that in doing so they took a legal risk.

This is an enticing suggestion. As will be discussed in Part VI, numerous features of these cases, such as the extreme time constraints they tend to impose, make them poor candidates for adjudication. Yet the suggestion is also troubling for several reasons, some eminently practical, others more theoretical. Although it is beyond the scope of this

280. See Kerenyi \& Chitkara, Correspondence to the Editor, 305 NEw ENG. J. MED. 1219 (1981).

281. One could object that vaginal delivery causes harm, while in the abortion hypothetical the fetal harm is preexisting. But if the defect is so severe that the child's life would be a continuing harm to it, then the act that would prevent this further harm is an abortion, much as the act of surgical delivery will prevent additional fetal damage from hypoxia.

282. Margery Shaw, however, embraces the possibility of compulsory prenatal diagnosis and even abortion along with her arguments in favor of an array of mandatory prenatal treatments and interventions. Shaw, supra note 86 , at 88.

283. Both Jay Katz and John Arras have suggested this approach to me. 
Article to give full attention to this proposal, I will briefly indicate why it should not be adopted.

First, hospital administrators and risk managers, to whom doctors will turn, tend, in iny experience, to approach these problems not from the perspective of patients' rights and physicians' moral duties, but from a risk/benefit perspective in relation to legal hability. ${ }^{284}$ In other words, they reason that if surgery is performed and, as expected, the woman is fine and the imfant is in good condition, the woman is unlikely to sue, and if she does, unlikely to be able to prove any real damages. On the other hand, if her refusal is honored and the baby is profoundly impaired, a subsequent suit by the mother could present a very appealing case. She might allege that she did not really understand the consequences of her refusal. It is also possible that a third party might sue on behalf of the child, claiming that it was harmed by physical inaction, and that the mother's refusal should have been challenged. Because hospital counsel and/or risk managers fear such actions, they will probably advise doctors to coerce these women, at least if coercion can be accomphshed without actual physical violence. ${ }^{285}$ It is likely, then, that if courts stay out they will be imphicitly sanctioning physician control.

On a more theoretical level, a "hands off" approach raises problems of equal treatment and fairness. Courts do not refuse to decide cases im which physicians seek to override treatment refusals of competent patients; they uphold the patient's right. Nor do they refuse to decide cases such as McFall $v$. Shimp, ${ }^{286}$ in which one party seeks to impose duties to rescue on the other, even though such cases arise quite rarely. A selective refusal to get involved in these maternal/fetal conflict cases suggests that pregnant women, unlike other citizens, can be used as the means to promote another's good if physicians are willing to assume the legal risk of doing so. Just as there are problems with a court's requiring pregnant women to hive up to the ideal of the good or virtuous mother, there are problems of fairness if the state decides that it will not enforce

284. Fear of legal liability and large monetary damages if the infant was impaired was definitely a factor in the Headley case at North Central Bronx Hospital, and was a major subject of discussion at the ethics rounds that I attended prior to the lawsuit. See supra note 10. It was likewise a consideration in the Colorado case. See generally Bowes \& Selgestad, supra note 3, at 211.

285. The risk manager at North Central Bronx stated that the doctors could simply operate, even without a court order, upon Mrs. Headley, so long as she presented herself to the hospital and the operation was needed to preserve the fetus. Statement of Opal Dunston, Risk Manager, North Central Bronx Hospital, at Obstetrics Ethics Rounds (Dec. 19, 1985). Indeed, this view is also adopted by a number of attorneys at the New York City Health and Hospitals Corporation, which is counsel to the city hospitals. Interviews with Salvatore Russo, Associate Counsel, Health and Hospital Corporation, New York City (Jan. 10, 1986), Nancy Gold, attorney for Bower \& Gardner and counsel for North Central Bronx Hospital in the Headley case, New York City, (Jan. 13, 1986) (affirming that this position is taken at HHC, but expressing her disapproval of it).

286. 10 Pa. D. \& C.3d 90 (1978). 
moral obligations but at the same time it will not prevent doctors from doing so.

These problems are exacerbated when we consider other actions doctors might begin to take in pursuit of fetal health. As Laurence Tribe has said im regard to the state's harming one person to benefit another:

Even if one does not believe that human sacrifice is never justifiable, courts have long recognized the wisdom of acting as though persons could never be used as means to the ends of others, knowing that any clear departure froin that ideal could spell the beginning of a disastrous slide. 287

Plysicians are faced with a myriad of situations in which women's conduct may harm the fetus. If courts refuse forthrightly to uphold women's riglits to make their own medical cloices, we might next see doctors mandatimg fetal monitoring and fetal blood scalp sampling, or even coercively lospitalizing pregnant women who take drugs or fail to take medications such as insulin (tliough it is hard to imagine the latter types of actions going fortli without court involvement). In light of the disparity in power between patient and pliysician, and the probable results if courts refuse to decide, it is important that courts finnly uphold the woman's riglit to decide, despite the potentially tragic consequences. Such consequences make this solution far from ideal. But to place pregnant women in the vanguard of a new societal movement to enforce moral obligations, when it is very likely that this movement will go no furtler than pregnant women, is even more unpalatable.

\section{VI}

\section{THE REAI WORLD OF INTERVENTIONIST OBSTRETICS}

For my legal and ethical arguments up to now, I have assumed that the consequences of uplolding a refusal will be tragic, Although I believe that this is likely in any particular case, the chances of its being true in a given case probably are not as high as the reader unfamiliar with medical teclinology and decisionmaking miglit assume. This Part will describe some of the limitations of the teclinology upon which doctors rely in predicting fetal liarm. It will also discuss the numerous factors that influence doctors to be very conservative and risk-averse in their decision strategies, to diagnose a problem even when one merely might be present, and to intervene very aggressively to treat the perceived problem. In addition, I describe a critique of American obstetrics that claims that many common medical interventions increase the likelihood of further interventions. One need not endorse this critique in toto or even in large part; even if just a portion of it is valid, in conjunction with the very

287. L. TRIBE, supra note $217, \S 15-9$ at 918 . 
real technical limitations, it suggests that in some cases the surgery that doctors are seeking will be unnecessary. Unfortunately, the almost inevitable time constraints and the one-sided posture of these cases mean that in such cases, judges will rarely be able to distinguish the necessary from the uunecessary surgery.

One might well feel very differently about a woman's refusal of surgery, or refusal of all major medical interventions in pregnancy, if such refusal could sunply reflect (whether the woman articulates this or not) a different, but possibly valid, approach to risk and to medical decisionmaking. If some medical interventions tend to increase the need for other interventions, then it may be the case that women who eschew all interventions run certain risks but avoid others. Whether or not one accepts this, there are additional societal problems with enforced surgery. For example, if a pohicy of mandating surgery when doctors believe it necessary becomes standard and known in the community, women with unusual religious or medical behefs may choose the riskier alternative of avoiding care altogether. Another is that if nonconsensual surgery becomes widely accepted, we may soon see compulsory intervention in a variety of circumstances-including, for instance, mandatory fetal inomtoring, ultrasound, administration of insulin to pregnant diabetics, or incarceration or detoxification of pregnant heroin addicts. The "shippery slope" is a very real problem here, and the shide is much easier if one begins with major surgery.

\section{A. Limitations of Obstetric Technology}

All obstetrical diagnostic technologies have their limitations. Generally, diagnoses of placenta previa by ultrasonography are exceptionally_ uncontroversial and accurate. But, even here, doctors may at times mistake a complete placenta previa for a more benign partial one, ${ }^{288}$ or the placental position may change between the time the sonograin was taken and delivery. Significantly, in Jefferson and Jeffries, where placenta previa indicated the need for Cesarean dehivery, the women gave birth vaginally. ${ }^{289}$ In the case of hypertension or preeclampsia the necessity of Cesarean delivery is much inore speculative. The recommendation of a Cesarean is based on a fear that complications may arise rather than a prediction that they will. ${ }^{290}$ Indeed, a leading inedical textbook stresses that Cesarean delivery is not necessary in most cases of preeclampsia and is needed ouly if fetal distress or life-threatening maternal complications

288. Cohen interview, supra note 125 .

289. See Annas, supra note 60, at 16 (Jefferson case); Detroit Free Press, June 16, 1982, at 3A, col. 4 (Jeffries case).

290. Shulman Interview, supra note 29. 
arise. $^{291}$ Hence, in the North Central Bronx case, it is not surprising that Mrs. Headley had a successful vaginal delivery in spite of her hypertension and preeclampsia. ${ }^{292}$ And predictions of fetal distress-the 1nost common fetal indication for surgical delivery-are enuneshed in a complex web of inedical limitations, uncertainties, and controversies.

A first, and very significant, difficulty faced by physicians attempting to predict fetal distress based upon fetal monitor results is simply that the problem screened for-fetal hypoxia during labor of sufficient severity to cause fetal damage-occurs only rarely in a population of normal, healthy women. ${ }^{293}$ Detecting rare medical conditions poses peculiar problems for even a highly accurate diagnostic test. The predictive value of a diagnostic procedure such as EFM is a function of three variables: (1) the procedure's specificity, that is, its number of correct classifications of normal states as normal; (2) its sensitivity, or nuinber of correct diagnoses of disease im the diseased population; and (3) the incidence of the disease or condition in the population studied. ${ }^{294}$ As the mcidence of the condition decreases in frequency, it becomes increasingly likely that positive diagnoses are really false positives.

To illustrate the difficulty mvolved in diagnosing rare conditions, Banta and Thacker, authors of a comprehensive study of the costs and benefits of EFM, note that if the prevalence rate of a disease or condition is 10 per 1000 , and the test for it is $80 \%$ sensitive and $90 \%$ specific, the predictive value of the test for normalcy will be $99.8 \%$, but the predictive value for the disease will be only $7.5 \% .^{295}$ Over $90 \%$ of the people informed they have the condition will not really have it. Even if the condition is more common, occurring in 50 per 1000 in the population tested, and the test is more accurate- $95 \%$ sensitive and $95 \%$ specificstatements of normalcy will be accurate $99.7 \%$ of the time, but diagnoses of disease will be correct only $50 \%$ of the time. ${ }^{296}$ This problem of false positives is inherent in an attempt to diagnose relatively rare conditions. To avoid high false positive rates, a diagnostic tool must be extremely

291. S. Cherry, R. Berkowitz \& N. KASE, supra note 29 , at 134 . If preeclampsia becomes very severe, immediate delivery is usually necessary, but even then it often can be effected by induction of labor. Schulman Interview, supra note 29.

292. It is interesting to note that the midwife who had provided prenatal care to Mrs. Headley throughout her pregnancy felt that her condition was cause for concern, but not for the degree of alarm signified by seeking a court order for nonconsensual surgery. In addition, the midwife felt that absence of the standard symptom of preeclampsia-protein in the urine-indicated that Mrs. Headley might be a chronic hypertensive rather than have the more dangerous preeclampsia condition. Interview with Beverly Robertson, Midwife, North Central Bronx Hospital (Feb. 20, 1986).

293. Friedman, The Obstetrician's Dilemma: How Much Fetal Monitoring and Cesarean Section Is Enough?, 315 NEW ENG. J. MED. 641 (1986).

294. Banta \& Thacker, supra note 36 , at 629 .

295. Id. at 630 .

296. Id. 
(greater than 99\%) specific. ${ }^{297}$

The conditions or events being tested for by EFM are unquestionably rare. Neonatal mortality (death within 28 days after birth) was 9.8 per 1000 in 1977, and perinatal mortality (combimed fetal and neonatal deaths) is, according to several studies, approximately double that. ${ }^{298}$ Perinatal deaths caused by asphyxia during labor, and thus potentially preventable by EFM, are even less frequent. Deaths of fetuses are substantially more hikely to occur before labor than during it, ${ }^{299}$ and are most commonly caused by prematurity. ${ }^{300}$ The most common cause of neonatal mortality is also prematurity. ${ }^{301}$ Low birthweight accounts for three-fourths of all neonatal deaths, ${ }^{302}$ and the majority of full-term babies have a risk of neonatal death at or below 1 per $1000 .^{303}$ Fetal brain damage that occurs during delivery, again potentially preventable by $\mathrm{EFM}$, is also rare. ${ }^{304}$ Only $10 \%$ of mental retardation is attributable to avoidable antenatal and early postnatal problems ${ }^{305}$ and cerebral palsy is similarly more commonly related to problems before the onset of labor. $^{306}$ It is estimated that under ideal circumstances, EFM could prevent at inost 3 deaths per 1000 hive births, and 1 case of severe mental retardation and cerebral palsy per 1000 live births. ${ }^{307}$

Given the low prevalence of the problems EFM seeks to detect, it is not surprising that randomized controlled trials of the effectiveness of universal use of EFM show either no impact on perinatal mortality ${ }^{308}$ or

297. Id.

298. Id. at 632; Williams, Cunningham \& Norris, Fetal Growth and Perinatal Viability in California, 59 OBST. \& GyNECOL. 624, 626 Table 1 (1982).

299. Placek, Keppel, Taffel \& Liss, Electronic Fetal Monitoring in Relation to Cesarean Section Delivery, for Live Births and Stillbirths in the U.S., 1980, 99 PUB. HEALTH REP. 173, 179 (1984) (82.8\% of fetal deaths occurred before labor); R. FreEman \& T. GARITE, FeTAL Heart Rate MoNITORING 172 (1981) (more than $70 \%$ of fetal deaths occurred before labor).

300. Banta \& Thacker, supra note 36 , at 632 .

301. Id.

302. Rosenbaum, The Prevention of Infant Mortality: The Unfulfilled Promise of Federal Health Programs for the Poor, 17 ClEAR1NGHouse REv. 701, 702-03 (1983). The most premature babies are at the greatest risk. See Philip, Little, Polivy \& Lucey, Neonatal Mortality Risk for the Eighties: The Importance of Birth Weight/Gestational Age Groups, 68 PED1ATRICs 122, 129 (1981) (death rate for infants born at less than 26 weeks may be as high as $90 \%$ ).

303. Neutra, Feinberg, Greenland \& Friedman, Effect of Fetal Monitoring on Neonatal Death Rates, 299 NEw ENG. J. Med. 324, 326 (1978) [hereinafter Effect of Fetal Monitoring].

304. Friedman, supra note 293, at 642 (most fetal damage cannot be prevented because it is related to events or factors that occur before delivery, and over which physicians have no control).

305. Banta \& Thacker, supra note 36 , at 634.

306. Id. See generally Cesarean Childbirth, supra note 17, at 387; National INSTITUTE of Health, National institute of Child Health and Human Development, ANTEnatal. Diagnosis: RePort of Consensus DeVelopment Conference III-23 (1979) [hereinafter ANTENATAL DIAGNOSIS] (20\%-40\% of cerebral palsy cases believed to be caused by intrapartum events).

307. Banta \& Thacker, supra note 36 , at $632-34$.

308. Four trials completed by 1979 are described in Banta \& Thacker, supra note 36, at 633. 
an extremely small impact. ${ }^{309}$ Nor is it surprising that a normal heart pattern on the monitor is a very reliable indicator of a well-oxygenated fetus (in substantial part because most fetuses are in fact well-oxygenated ${ }^{310}$, but an abnormal fetal heart pattern is far less precise an indicator of fetal problems. In studies assessing the correlation between abnormal fetal lieart rate patterns and low Apgar scores, the rate of false positives from EFM has ranged from $18.5 \%$ to almost $80 \% .^{311}$ One expert estimates that predictions of fetal distress froin abnormal heart rate patterns have an approximately $30 \%$ to $50 \%$ accuracy rate. ${ }^{312}$

Two of the studies were carried out on high-risk women at the University of Colorado. The first compared auscultation (noninvasive aural monitoring of fetal heart rate) to EFM and found no measurable difference in neonatal outcome. See Haverkamp, Thompson, McFee \& Cetrulo, The Evaluation of Continuous Fetal Heart Rate Monitoring in High-Risk Pregnancy, 125 AM. J. OBSTET. \& GYNECOL. 310, 312 (1976). The second compared auscultation to EFM alone, and to EFM with blood scalp sampling. There was no measurable difference in neonatal outcome among the three groups. See Haverkamp, Orleans \& Langendoerfer, supra 26, at 404. An English study that did not include fetal blood scalp sampling also found no measurable difference in outcome between the groups. See Kelso, Parsons, Lawrence, Arora, Edmonds \& Cooke, An Assessment of Continuous Fetal Heart Rate Monitoring in Labor, 131 AM. J. OBSTET. \& GYNECOL. 526, 531 (1978). Only in an Australian study, which routinely included fetal blood scalp sampling as a part of fetal momtoring, was there any difference. Neonatal mortality and Apgar scores were still similar in the two groups, but the incidence of neurological abnormalities at birth was higher in the auscultation group, and more infants in that group required intensive care. See Renou, Chang \& Anderson, Controlled Trial of Fetal Intensive Care, 126 AM. J. OBsTET. \& GYNECOL. 470, 473 (1976). All of these studies have been criticized on the grounds that their patient samples were too small to establish small degrees of difference that are significant statistically. See Banta \& Thacker, supra note 36, at 633; FREENAB \& GARUTE, supra note 299, at 168 (suggesting that it would take approximately 18,000 patients in a randomized controlled trial to prove no difference between the fetal monitoring and auscultated groups).

309. Effect of Fetal Monitoring, note 303, at 325-326 (failure to monitor increases risk of neonatal death 1.4 times). Even though this study included more than 16,000 patients, it still required extrapolation of this conclusion from its findings. Banta and Thacker note that this finding is consistent with the studies showing no difference in mortality, because a difference this small would require a study of more than 100,000 women to find a statistically significant difference. Banta \& Thacker, supra note 36, at 633; ANTENATAL Diagnosis, supra note 306, at III-64-65. The efficacy of EFM in low-risk pregnancies is particularly problematic. Banta \& Thacker, supra, note 36 , at 633 , concluded that it is of little benefit to low-risk women. In analyzing the large Neutra study, Banta and Thacker concluded that use of EFM in the $26 \%$ of labors with demonstrable risk factors would avert $87 \%$ of potentially preventable deaths. See Effect of Fetal Monitoring, supra note 303, at 325, for the data from which Banta \& Thacker drew this conclusion. A very recent study confirming this is Levino, Cunningham, Nelson, Roark, Williams, Guzick, Dowling, Rosenfeld \& Buckley, A Prospective Comparison of Selective and Universal Electronic Fetal Monitoring in 34,995 Pregnancies, 315 NEw ENG. J. MED. 615, 618 (1986) (universal monitoring did not improve mortality or morbidity rates over those achieved by selective monitoring of high risk pregnancies only); see also Haverkamp \& Orieans, supra note 32, at 121 (citing expert's estimate that assessment of EFM's effect on perinatal death rates in full term, low-risk patients would require 180,000 monitored patients and 180,000 unmonitored ones, and that "[t]he very size of the required groups casts doubt on the need for universal use of EFM, since obviously very low incidence problems are involved.")

310. Banta \& Thacker, supra note 36 , at 630.

311. Id. at 628-29.

312. Miller, Prediction of Acid-Base Values from Intrapartum Fetal Heart Rate Data and Their 
Of course, this problem is ameliorated to some extent if EFM is combined witl blood scalp sampling, because in cases in which an ominous heart pattern is associated witl a low $\mathrm{pH}$ level, doctors can be much more certain that the fetus is in trouble. ${ }^{313}$ Nonetheless, altliough the blood $\mathrm{pH}$ theoretically is a reliable indicator of fetal oxygenation, in practice fetal blood scalp sampling as a test is not so reliable. Alterations in $\mathrm{pH}$ level can result from maternal position, drugs used during labor, vasoconstriction in the fetus, or fetal scalp edema. ${ }^{314}$ There can also be mechamical errors im performing tlie test. ${ }^{315}$ Consequently, many diagnoses of acidosis in the fetus are false positives. Whien Apgar scores are coinpared to acidosis diagnoses, the false positive ratio of fetal scalp blood sampling has typically been found to be from $20 \%$ to $50 \%{ }^{316}$ According to tlie Office of Technology Assessment, even when EFM and fetal scalp blood sampling are used together, the false positive rate is $44 \% .^{317}$

In terms of actual predictions of fetal damage, this false positive proble1n is even more serious that the above discussion suggests. All tliese correlations are with Apgar scores. The Apgar score is the most accurate measure of newborn liealtli status. At the extreine, wlien scores are 0 to 1 , it predicts deatli or morbidity quite well. ${ }^{318}$ Nonetlieless, there are a large number of false positives. In fact, one large collaborative study found that between $90 \%$ and $95 \%$ of surviving cliildren who had 5 -minute Apgar scores of 3 or less were of normal imtelligence several years later. ${ }^{319}$ Thus, assessinents of the accuracy of EFM and fetal scalp sampling involve coinparing tliese tests to another test that itself has a higli false-positive rate. ${ }^{320}$

Compounding these probleins is the fact that EFM is by no means a simple or straiglitforward test. It requires sophisticated and knowledgea-

Correlation with Scalp and Funic Values, in 9 Clinics In Perinatology: Symposium on Fetal Monitoring 353, 353 (R. Petrie ed. 1982).

313. One study found that only $23 \%$ of variable decelerations and $34 \%$ of late decelerations (two of the ominous fetal heart rate patterns) were associated with a fetal scalp blood pH of less than 7.25. Banta \& Thacker, supra note 36 , at 629 . Another author notes that only $20 \%$ to $40 \%$ of ominous fetal heart rate patterns are associated with fetal $\mathrm{pH}$ values that are considered acidotic. Haverkamp, Orleans \& Langendoerfer, supra note 308, at 406.

314. Banta \& Thacker, supra note 36 , at 629.

315. Id.

316. Id. at 629-30.

317. Id. at 629 .

318. Id. at 628 .

319. Haverkamp \& Orleans, supra note 32, at 121 (citing Broman, Perinatal Anoxia and Cognitive Development in Early Childhood, in INFANTs BORN AT RISK (T. Field, A. Sostek \& S. Goldberg eds. 1978)).

320. It has long been suggested that to determine the effect of EFM on long-term neurological outcome would require at least 1500 births and 7-10 years of follow-up. Banta \& Thacker, supra note 36 , at 634 . 
ble interpretation of the inonitor patterns, and obstetricians do not always agree about the interpretation of abnormal fetal heart patterns. For example, when 12 national EFM experts were asked to interpret 14 abnormal heart patterns, on average any two physicians agreed $68 \%$ of the time to classify the patterns as "innocuous," "nonreassuring," or "ominous." In deciding between continuing the inonitoring and immediate dehivery when the patterns persisted after corrective treatment, the experts' average agreement was $69 \%{ }^{321}$ When scalp blood sampling was also considered the average agreement was $59 \% .^{322}$ No two practitioners used the same set of criteria to distinguish oninous fetal heart patterns fron 1 nonreassuring ones, ${ }^{323}$ and the experts showed substantial differences in (1) the degree of alarm-the number of patterns thought oininous, and (2) interventionisin - the number of cases in which immediate delivery was chosen. ${ }^{324}$

If all this were not enough to raise doubts about medical prognostication, there would still be the problein that niost of the literature about EFM interpretation and accuracy is by national experts and concerns practices at inajor academic institutions. The authors of the study of EFM interpretation described in the preceding paragraph stress that "a broader, inore representative sample of obstetricians would include many individuals less thoroughly conversant with the hiterature on EFM than the persons interviewed, and therefore night reveal greater diversity of attitudes." 325 Other studies note that "it is not uncommon to observe overreaction to beingu inonitor patterns in hospitals where the staff is not well trained in monitor interpretation." 326 Overreaction is particularly likely to lead to unnecessary Cesareans if doctors do not-or cannotperform a fetal blood scalp sampling. ${ }^{327}$ Unfortunately, it appears that scalp blood sainpling is only rarely performed outside of acadenic institutions. ${ }^{328}$ Finally, it is relatively easy for national experts in a study of EFM to engage in sophisticated interpretation of monitor patterns and to

321. Cohen, Klapholz \& Thompson, Electronic Fetal Monitoring and Clinical Practice, 2 Medical Decision Making 79, 84 (1982).

322. Id. at 85-86.

323. Id. at 91 .

324. Id.

325. Id. at 87.

326. R. FREEMAN \& T. GARITE, supra note 299, at 171; see also L. CiBILS, supra note 34, at 479 ("[T]he analysis of recordings by inadequately trained individuals will logically increase the number of cesarean sections by 'overcalling' some FHR alterations. The need for experience and caution when evaluating an electronic monitoring record cannot be overemphasized.")

327. Fetal blood scalp sampling requires ruptured membranes, minimal cervical dilation of 2 to $3 \mathrm{cms}$., and an accessible fetal part. It is technically difficult as well, and a single value is rarely conclusive because pH can vary based on such things as uterine contractions. See Schifrin, The Fetal Monitoring Polemic, in 9 Clinics in Perinatology: Symposium on Fetal Monitoring 399, 406 (R. Petrie ed. 1982).

328. Id. at 406 . 
be conservative in their recommendations for Cesarean dehvery. It is far harder for ordinary doctors, faced with a woman in labor and the possibility of a brain damaged child and a multi-million dollar lawsuit to exercise similar restraint. ${ }^{329}$ Surgery, whether necessary or not, will always carry far less legal risk with it than allowing a woinan to continue laboring in the face of questionable fetal inonitoring data. ${ }^{330}$

\section{B. The Maximin Strategy in Obstetrics}

The limitations just discussed are coinpounded by the prevailing "maximin" decision strategy in American obstetrics. ${ }^{331}$ A naximin strategy focuses on the worst possible outcome in a situation of uncertainty (here, fetal death or damage), and takes action to prevent that outcome, regardless of the outcoine's actual probability of occurrence. ${ }^{332}$ The routine use of EFM in low-risk pregnancies is an exainple of maximin strategy, in that the prevalence of the problein screened for is low, the number of false positives high, and the resulting action often very aggressive (for example, a Cesarean). It is beyond the scope of this Article to describe in full the numerous and heated debates about the validity of standard American obstetrical practice. ${ }^{333}$ Nevertheless, because the judge who orders a Cesarean-the last link in the obstetrical intervention chain-necessarily affirms this prevailing approach, we should briefly review the debate surrounding the inaximin strategy, including the clain that the strategy itself can create the need for Cesarean delivery.

A number of routine procedures used to inonitor or influence the progress of labor may slow labor or increase the need for intervention. Both slow labor and various inedical interventions increase the chances of Cesarean dehivery. At the most basic level, for exainple, the supime position assuined in inost hospital births-a position that facilitates vagi-

329. Dr. Cohen, among others, has stressed that the fear of liability influences monitor interpretation. Cohen interview, supra note 125.

330. See infra notes 359-60 and accompanying text; see also S. ARMS, IMmaculate DECEPTION: A NEW LOOK AT WOMEN AND CHILDBIRTH 74 (1975) (quoting one doctor as saying that although he is aware of the inaccuracies of fetal monitoring data, a $25 \%$ chance of accuracy is reason enough for him to terminate labor and do a Cesarean.).

331. Brody \& Thompson, The Maximin Strategy in Modern Obstetrics, 12 J. FAM. Prac. 977 (1981).

332. Id. at 977.

333. For a sampling of the large and growing body of literature criticizing the medical interventionism prevalent in American obstetrics, see THE Boston WOMEN's HEALTH BooK Collective, The New Our Bodies, OuRselves (1984); Y. BraCkBIIl, J. Rice \& D. Young, BirThtrap: The Legal Low-Down on High-Tech Obstetrics (1984); G. Cassidy-Brinn, F.

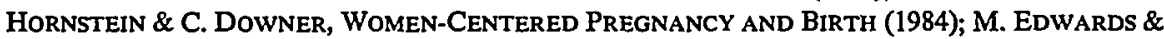
M. Waldorf, Reclaiming Birth: History and Heroines of AMerican Childitrth Reform (1984); S. Romalis, Childbirth: Alternatives to Medical Control (1981); B. Rothman, supra note 20; Corea, The Cesarean Epidemic, Mother Jones, July 1980, at 28. 
nal examinations and episiotomy ${ }^{334}$ and is required for some types of EFM-is criticized for sometimes slowing labor. ${ }^{335}$ Amniotoiny (rupturing the membranes) is a very common intervention and is widely regarded as one of the least harmful. ${ }^{336}$ It is used to induce or speed labor and is also required for internal monitoring. However, amniotomy increases the risk of infection in prolonged labors. ${ }^{337}$ Once the membranes have ruptured, inany hospitals allow labor to continue only for a fixed number of hours-usually twenty-four. ${ }^{338}$

Physician-imposed time constraints are important for interpreting National Institute of Health statistics showing that dystocia (dysfunctional labor) contributed 30\% to the rise in Cesareans between 1970 and $1978 .^{339}$ It is highly improbable that during this time, pregnant women in this country experienced a substantial increase in dysfunctional labor. Rather, inedical definitions of "failure to progress" in labor have changed over time. ${ }^{340}$ Although suggestions as to the normal duration of labor vary, ${ }^{341}$ the NIH Task Force notes that doctors may unnecessarily label slow or lengthy labors as dysfunctional or abnormal. ${ }^{342}$ Doctors may also cause labor to slow or stop by using epidural anesthesia or other painkillers. ${ }^{343}$

Once a labor is diagnosed as abnorinally slow, doctors may try to

334. Episiotomy is the surgical cutting of skin arouud the perineum to enlarge the opening for birth. After birth, the cut must be sutured. Y. BRACKBILL, J. RICE \& D. YouNG, supra note 333, at 14.

335. One obstetrician has been quoted as saying: "Except for being hanged by the feet, the supine position is the worst conceivable position for labor and delivery." Id. at 12.

336. Brody \& Thompson, supra note 331, at 980.

337. See id.; G. CASSIDY-BrinN, F. HoRNSTEIN \& C. Downer, supra note 333, at 139. Critics suggest that the cause of the increased infection risk is the frequent vaginal exams conducted in hospitals, and that without exams labor could continue much longer after rupture of meinbranes without risk of infection. See Corea, supra note 333, at 30.

338. G. CASSIDY-BRINN, F. HoRNSTEIN \& C. DOWNER, supra note 333, at 139. Corea, supra note 333 , at 30 , notes that at some hospitals the limit is only 12 hours.

339. CeSAREAN ChILDBIRTH, supra note 17, at 7. Diagnoses of fetal distress contributed 10 $15 \%$ of this rise, and other factors such as repeat Cesareans and the increasing tendency to operate for breech deliveries have significantly influenced the rise as well. Id.

340. One critic, after noting that obstetrical texts suggest a normal labor duration for a first baby is up to 24 hours, states: "These books, however, confuse what was once considered to be an average number of hours in labor with the normal, healthy length of labor." G. CAssidY-BRINN, F. HORNSTEIN \& C. DOWNER, supra note 333, at 145 (emphasis in original); see also Y. BRACKBILL, J. RICE \& D. YouNG, supra note 333, at 28-29 (remarking that labor time has not changed, but that doctors' definition of "slow labor" has). Brackbill quotes Dr. Andrew Fleck, Director of the Division of Maternal and Child Health in New York, as saying that "Cesarean section is a provider attribute and not an attribute of the woman . ..." Id. at 28-29.

341. CESAREAN ChILDBIRTH, supra note 17, at 339-42. Delivery for all patients in less than 24 hours has been advocated, as has intervention after two to four hours of poor progress in active labor. Id. at 342 .

342. Id. at 343 .

343. See Brody \& Thompson, supra note 331, at 981; Y. BRACKBILL, J. RICE \& D. YouNG, supra note 333 , at 17 . 
speed it up by using the hormone oxytocin. Oxytocin, however, can cause excessively strong contractions that increase pain and the need for painkillers, ${ }^{344}$ and that can even create fetal distress. ${ }^{345}$ As one national expert on EFM stated, "The most frequent cause of late decelerations in term labors in the United States must be hypercontractility triggered by the misuse of oxytocic substances." 346 Because of oxytocin's risks, EFM must be used when it is administered. ${ }^{347}$ In the end, EFM increases the Cesarean rate by yielding both accurate and inaccurate diagnoses of fetal distress.

EFM's inupact on the Cesarean rate appears to be significant. The NIH attributed $10 \%$ to $15 \%$ of the rise in Cesarean rates to increased diagnoses of fetal distress. ${ }^{348}$ Randomized controlled trials consistently have shown noore surgical dehveries in inonitored women. ${ }^{349}$ Moreover, this difference reflects not only more diagnoses of fetal distress, but also increased diagnoses of seemingly unrelated problenis such as the failure to progress. ${ }^{350}$ One expert suggests several reasons for this:

344. See Y. BRACKBILL, J. Rice \& D. Young, supra note 333, at 17.

345. Id. at 9. Discussions on how to alleviate fetal distress routinely suggest that if oxytocin is being administered, it should be reduced or stopped. See Banta \& Thacker, supra note 36, at 628 . Unfortunately, starting and then stopping oxytocin may cause a natural labor to slow or stop altogether.

346. L. CIBILS, supra note 34 , at 322 (emphasis in the original).

347. See Brody \& Thompson, supra note 331, at 981 (value of EFM during oxytocin adininistration well accepted).

348. Cesarean ChildbirTh, supra note 17, at 7. NIH notes that this does not mean there is more fetal distress-only that it is more frequently diagnosed. Id. at 14-15.

349. Banta \& Thacker, supra note 36, at 631 , summarize the Cesarean rates in four studies of EFM. They are: Australian study-18\% in EFM group, $10 \%$ in auscultated group; English study-9\% in EFM group, $4 \%$ in auscultation group; 1st Haverkamp study-16.5\% in EFM group, $6.6 \%$ in auscultation group; 2nd Haverkamp study-18\% in EFM-only group, $12 \%$ in EFM plus fetal blood scalp sampling, and $6 \%$ in auscultated group. A subsequent trial likewise showed a higher rate of operative deliveries associated with EFM. Wood, Renou, Oats, Farrell, Beischer \& Anderson, A Controlled Trial of Fetal Heart Rate Monitoring in a Low Risk Obstetric Population, 141 AM. J. OBSTET. \& GYNECOL. 527, 529-30 Table iii (1981). The argument is sometimes made that Cesareans based on abnormal fetal heart patterns are almost always justified, because they simply prevent disasters that might have subsequently occurred. For example, one EFM proponent claims that "the delivery of a good infant following FHR (fetal heart rate) alterations that indicate impending or developing problems should be considered a therapeutic success rather than labelled as a false alarm." L. CiBILS, supra note 34, at 483 . Indeed, this will sometimes be the case. But to suggest that it will always be the case incorporates a Catch-22 type of circularity that effectively elininates the possibility of validating or invalidating fetal monitor results. This is reminiscent of some psychiatrists' claim that denial of mental illness is itself a symptom of mental illness: while it often may be so, the claim cannot be disproved because every possible circumstance supports it. Elsewhere in his treatise Cibils recognizes that late decelerations are only a relative predictor of neonatal status. He observes that $35 \%$ of fetuses with late decelerations during the first stage of labor were depressed during the first minute of life, as opposed to $9 \%$ being depressed who had no decelerations. Id. at 330. Undoubtedly an even smaller number had lasting neurological deficits.

350. Haverkamp, Orleans \& Langendoefer, supra note 308, at 404 Table xii (5\% Cesarean rate for reasons other than fetal distress in the auscultated group, $11 \%$ for reasons other than fetal distress reasons in the EFM-only group, and $8 \%$ for reasons other than fetal distress in the EFM 
1. EFM restricts activity. In particular, the external monitor forces a woman to lie on her back. If she moves very much, the fetal heart rate sign is lost.

2. Overly strict criteria are used for what is termed "failure to progress" with a momitor in place. If external monitors are used, they tend to make contractions appear more effective (on the graph paper) than they may actually be. ${ }^{351}$

Even proponents of routine monitoring note that the relative immobilization of a momitored patient, especially when combined with some patients' fear of the momitor, can slow labor, reduce maternal blood pressure, and, in extreme cases, interfere with adequate blood flow to the fetus. $^{352}$ Thus, in soine cases monitoring inay produce the very problems it subsequently detects. ${ }^{353}$

Even with well-documented risk factors such as hypertension or preeclampsia, it inay be that the medical treatinent itself necessitates a Cesarean, thus rendering the doctor's dire prediction a self-fulfllling prophecy. It has been noted that:

Over-enthusiastic use of antihypertensive drugs will cause a relative or real hypotension with consequent fall in IVS blood flow and fetal hypoxia. This conplication is particularly likely with the multidrug method of treating severe hypertension or preeclampsia still widely used at many centers. It is not widely known that a significant reduction, on the order of $50 \%$, in the IVS blood flow is required before a well fetus reacts with a lyypoxic deceleration and niakes other associated adaptive responses; that much of a reduction is easily reached by mducing a fall in the blood pressure. $^{354}$

Hypertensive or preeclamptic women may also require surgery when physicians have attempted but failed to induce labor early with oxytocin. ${ }^{355}$ Thus, while soine Cesarean dehveries may be necessitated by hypertension, preeclampsia, or both, others may be necessitated by the standard medical treatment for these conditions. These latter operations are not unnecessary; rather, the very real need for them has iatrogenic (treatment-induced) origins.

As this brief discussion illustrates, the various obstetrical interventions are not unrelated, but instead "form an interconnected system, with one intervention leading to additional risk factors or additional data

plus scalp sampling group). Other studies have yielded similar findings. See, e.g., Kelso, Parsons, Lawrence, Arora, Edmonds \& Cooke, supra note 308, at 531 (finding a statistically significant increase in Cesareans in the EFM groups versus auscultated groups for reasons other than fetal distress).

351. Haverkamp \& Orleans, supra note 32 , at $130-31$.

352. L. CiBiLs, supra note 34 , at 478.

353. See Y. BRACKBILL, J. RICE \& D. Young, supra note 333, at 11.

354. L. CiBILs, supra note 34 , at 322-25.

355. Shulman interview, supra note 30. 
gathering needs, which in turn require new interventions .... Studying one intervention in isolation will lead to an inflated assessment of its effectiveness."356 The benefits of the prevailing maximin strategy have not been proved, and it is not known whether "actmg in a maximin manner actually makes it inore likely that the worst possible case will occur."357 Thus, a woman-even one at high-risk —who refuses inedical intervention inay be running soine risks but avoiding others. Therefore, courts that authorize doctors to do whatever they deein best are embracing one inode-and a controversial one-of obstetrical practice. ${ }^{358}$

In addition, these courts are embracing a mode of practice that is mfluenced not only by what is considered inedically inost appropriate, but what is legally most defensible. Obstetricians are, with good reason, very aware of the possibility of a lawsuit if an infant is impaired. A substantial number of suits allege failure to make timely surgical intervention, ${ }^{359}$ and studies of Cesareans demonstrate that fear of hability is an important factor in deciding to dehiver surgically. ${ }^{360}$ Necessary or not, a Cesarean is the sort of strong offense that constitutes the best defense. As discussed previously, $\mathrm{m}$ at least two of the court-ordered Cesarean cases fear of liability was a serious consideration, and hospital risk managers' primary or sole approach to the Cesarean conflict is often risk-

356. Brody \& Thompson, supra note 331 , at 978 . Brody gives the following example to illustrate this.

Consider, for example, a population of obstetrical patients, many of whom undergo oxytocin augmentation during labor. If one uses such a population to test the hypothesis that routine fetal monitoring confers benefit, the monitored group may well demonstrate a better outcome than the unmonitored group. But, if one were studying oxytocin and fetal monitoring together as parts of a system of intervention, one would be obligated to compare these women to a control group that had neither oxytocin nor monitoring. Such a comparison might show no significant benefit for the oxytocin plus moritoring group; that is, the additional benefit from the monitoring merely served to counteract the increased risk from the oxytocin.

Id.

357. Id. at 977. As Brody notes, "When interventions are assessed singly, the implicit assumption of the maximin strategy-that the strategy itself does not make a bad outcome more likely-goes largely unchallenged." Id. at 978.

358. This mode has been graphically described as follows:

We begin by restraining a woman early in her labor. We allow her to see the EM's chattering stylus and its winks; often we even torture her unnecessarily with hours of its staccato sounds at 150 beeps per minute and we watch the monitor and not her. She dare not interrupt our silent vigil. Anxiety gives way to fright and anger. Something-possibly catecholamines-causes her to have abnonnal contractions and these in turn cause arrest of labor and sometimes diminished uteroplacental blood flow. The supine position aggravates the latter. And we then apply the modern-day obstetric panacea-cesarean section.

Munsick, supra note 267 , at $410-11$.

359. George \& Quattrone, Obstetric. and Gynecologic. Malpractice, 81 J. MED. Soc'y N.J. 623, 625 (1984).

360. Marieskind, supra note 48, at 188; see also de Regt, Minkoff, Feldman \& Schwarz, Relation of Private or Clinic Care to the Cesarean Birth Rate, 315 NEw ENG. J. MED. 619, 623 (1986) (documenting that private patients have significantly more Cesarean deliveries, and suggesting that their physicians are more influenced by fear of legal liability). 
minimization. ${ }^{361}$

The previous discussion is not intended to endorse or refute this critique of obstetrics, which is highly controversial in its own right. Rather, it illustrates the extent to which obstetrical practice is encumbered by technological limitations and questionable decision strategies, and is exacerbated by physicians' legal and financial concerns. ${ }^{362}$ Yet in support of the critics, we should note that interventionist obstetrics is not a universal approach, and that excellent results can be achieved with less technological dependence and intervention. ${ }^{363}$

These results suggest that while it is reasonable for a woman and physician to choose the standard obstetrical approach of intervening if there is even some chance of a problem, it is also reasonable to reject the maximin approach. Hence, in some cases a woman's refusal of a Cesarean may exphicitly or implicitly reflect a different, but not necessarily invalid or irrational, approach to medical decisionmaking under conditions of certainty. A policy of authorizing doctors to take whatever steps are necessary to protect the fetus in cases in which it is potentially imperiled will inevitably autlorize soine unnecessary Cesareans and allow doctors inadvertently to manufacture the need for others.

Finally, even if the interventions pursuant to the maximin strategy were all completely justified in terms of neonatal outcome, a medical policy of "when in doubt, cut" increases maternal risk both for individual women and for labormg women as a group. Taking one study's estimate that EFM may save one in 1,500 infants, one medical critic argues that

361. This was clearly the approach of the risk manager at North Central Bronx Hospital, see supra notes 284 \& 285 and accompanying text.

362. The primary financial concern in these cases is fear of tort liability, although delivery practices of private doctors may sometimes be inappropriately influenced by the case and financial renumeration of surgical delivery as compared to vaginal. These factors may contribute to the enormous variation in Cesarean rates from hospital to hospital and physician to physician. See J. HERZFELd, SENSE AND SENS1BILITY IN ChildBiRTH 27-29 (1985) (comparing North Central Bronx Hospital's 1979 Cesarean rate of 9 percent to Boston's Beth Israel Hospital's 1981 rate of 20 percent). According to one study of physician's practices, Cesarean rates for doctors at the same hospital ranged from $6.9 \%$ to $37.0 \%$. H. KEYSER, WOMEN UNDER THE KNIFE: A GYNOCOLOGIST'S REPORT ON HAZARDOUS MEDICINE 66 (1984).

363. As of the late 1970's, $38 \%$ of women in the Netherlands gave birth at home or in a maternity home equivalent to the ordinary home in its deemphasis of technology. CESAREAN CHILDBIRTH, supra note 17, at 94 . The government seeks to discourage low-risk women from having a hospital birth by failing to fund fully hospitalizations that are not deemed medically necessary. Id. Between 1968 and 1975, the Cesarean rate in the Netherlands increased from an incredibly low $1.8 \%$ to a "high" of $2.8 \%$. Id. at 91 . Notably, in 1978, when the United States had an infant mortality rate of 13.8 per 1000 live births, the Netherlands had a rate of 9.6 per 1000 . Id. at 101. This disparity in infant mortality is probably more a result of the much greater extent of poverty in the United States or the lack of adequate routine prenatal care for poor women, than a reflection of different obstetrieal practices. See S. ARMS, supra note 330, at 48 (adequate prenatal care dramatically reduces perinatal mortality). 
we must compare this benefit to its potential cost in tems of maternal death. He states:

The cesarean section mortality rate is at least 1 in 1,000 operations. In 1975, there were $3,150,000$ live U.S. births. If EM saves 1 in 1,500 , it would have saved 2,000 babies in 1975 if applied to all laboring patients. Assuming an $8 \%$ over-all cesarean rate without EM, 240,000 cesarean deliveries would have occurred in 1975 with 240 maternal deaths. Doubling the cesarean rate with EM would then kill 480 women. For 2,000 babies saved we sacrificed 240 women-one woman for eight babies. Should not this information be provided to gravidas before obtainimg their informed consent for $\mathrm{EM}$ ? $^{364}$

The numbers are probably different today, ${ }^{365}$ but on a societal level the trade-off is still present-not to mention the numerous lesser maternal risks from surgical dehivery. Thus, a policy of court-ordered fetal protection, no matter how justifiable in a particular case, has as its corollary a societal decision to risk some small number of women to save a larger number of babies.

\section{Interventionist Obstetrics in the Courts}

It could be objected that while doctors may recommend surgery in questionable cases, thus giving rise to unnecessary Cesareans, they will not seek to mandate it in any but the most clearcut cases-those where, without surgery, disaster will unquestionably ensue. Indeed, two of the Cesarean cases, Jefferson and Jeffries, involved women with placenta previa, one of the most clearcut and uncontroversial indications for a Cesarean. ${ }^{366}$ The successful vaginal dehiveries in those two cases were surprising and unexpected, and these are not the sorts of situations im which critics of obstetrical interventionism would claim that the doctors were excessively alarmed. Nonetheless, these cases illustrate a very crucial point here: that physicians feel certain that disaster will ensue does not mean that it will.

Physicians' subjective feelings of certainty will be even less likely to translate imto objective certainty in situations in which they are relymg on technology with inherent limitations such as EFM. As one expert stressed, when doctors can legitinnately feel certam about the ominous import of monitor tracings, such as when the monitor shows a late termi-

364. Munsick, supra note 267, at 411 (citation omitted).

365. Other estimates of EFM's efficacy are that it may prevent 3 perinatal deaths out of 1000 under ideal circumstances. See Banta \& Thacker, supra note 36, at 632.

366. The surprising nature of a vaginal delivery after diagnosis of placenta previa is suggested by the title of a report on the Jefferson outcome. See Hubbard, supra note 5, at 214 n.60 (citing Berg, Georgia Supreme Court Orders Cesarean Section-Mother Nature Reverses on Appeal, 70 J. MED. A. GA. 451 (1981)). In this case, one cannot be sure whether the medical situation actually changed or the sonographers were mistaken in the first place. 
nal heart pattern, there is no time to go to court. ${ }^{367}$ If the baby is to be saved at all, immediate action is necessary. At that point, however, surgery might either fail to prevent death or save a severely brain damaged infant. $^{368}$ In other words, where there is certainty as to peril, it may sometimes be too late to prevent the damage.

A situation that almost becaine a court-ordered Cesarean illustrates the danger that unnecessary surgery will on occasion be ordered. An African woman failed to progress in labor satisfactorily, and the internal fetal inonitor revealed repetitive late decelerations in the fetal heart rate. ${ }^{369}$ No fetal scalp blood samplimg was done, even though the woman was between five and six centimeters dilated. ${ }^{370}$ The physician advised a Cesarean, but the woman and her husband adamantly refused. They argued that after they returned to Africa, there would be no available facilities for a repeat Cesarean. Consequently, the Cesarean would place the woinan at significant risk in future pregnancies. They also noted that doctors recoinmended a Cesarean for failure to progress during her first pregnancy, but she nonetheless dehivered vaginally. In this case a judge was contacted and indicated his willingness to order a Cesarean. Before any order could be issued, however, the woman progressed rapidly to the second stage of labor and dehvered an infant with excellent Apgar scores-scores that were not suggestive of fetal distress. ${ }^{371} \mathrm{Had}$ the labor taken even a hittle more tinne, this woman inight have been subjected to an unnecessary operation-in her case one that would have greatly increased her future reproductive risks.

Naturally, the above discussion is not meant to suggest that the physician will not be right in a great inany cases. ${ }^{372}$ Moreover, physicians are surely right when they stress that because the goal of gathering data about such things as fetal heart rate is to prevent damage before it can occur, achieving a good outcome despite ominous data does not necessar-

367. Cohen Interview, supra note 125; see also Hon, Epilogue, in 9 Clinics in Perinatology: SYMPOSIUM ON FETAL MONITORING 443, 446 (R. Petrie ed. 1982) (fetus has best chance for intact survival if continously monitored, provided the obstetrician can interpret the fetal heart rate patterns, and an emergency section can be done within 15 minutes).

368. Banta \& Thacker, supra note 36, at 634.

369. Medical Humanities Report, Michigan State University, Winter 1984, at 1.

370. Id.

371. Id.

372. See Leiberman, Mazor, Chaim \& Cohen, The Fetal Right to Live, 53 OBSTET. \& GYNECOL. 515, 515-16 (1979) (describing two cases in which women refused Cesareans and fetal death ensued). In the Colorado case where a Cesarean was ordered and performed, the infant was born with a very low 1-minute Apgar score and required hesuscitation, indicating that there was intrauterine oxygen deprivation. See Bowes \& Selgestad, supra note 3, at 210-11. Because surgery was performed after 9-1/2 hours of monitored fetal distress, the reporting physicians remarked, "That a more asphyxiated infant with poor neonatal outcome did not result after so long a duration of apparent fetal distress simply underscores the limitations of continuous fetal heart monitoring as a means of predicting neonatal outcome." Id. at 211. 
ily mean that the data or the approach taken were wrong-only that doctors discovered the problem in time. Certainly, inany or most women would want their doctors to use this conservative and time-honored medical strategy. But there are serious problems with courts' requiring a woinan to abide by this approach, inasmuch as it does mean that some unnecessary operations will be judicially mandated.

One problem with courts' essentially requiring a inaximin approach to obstetrical risks is that whether or not the physician's degree of alarm is warranted, a very prompt judicial decision is almost always required. ${ }^{373}$ Hence, judges who hear these cases will typically hear only the doctor's side ${ }^{374}$ and will learn little or nothing of the risks of surgical delivery or the ambiguity of many fetal diagnostic procedures. If they attempt to balance the maternal and fetal risks, judges will have no choice but to accept the plysician's assessment and, therefore, to implement his or her recommendations. This is analogous to holding a civil commitment proceeding without the potential im-patient present or represented. Unlike a civil commitment proceeding, however, where a short delay is seldoin a life-or-death inatter, here the time needed to provide the woman even inarginally adequate representation may render the proceeding futile (the damage having already been done), noot (the baby having already been born vaginally), or both. ${ }^{375}$ Given the very real time constraints, there is no solution to this. ${ }^{376}$ Tlus, a court that tries to balance risks and benefits will almost inevitably have to base its decision on a one-sided presentation of factors. Courts can avoid this only by limiting their inquiry to an evaluation of competency (if it is in question) and firmly refusing to overturn coinpetent refusals.

Along with one-sided decisionmaking is the threat that nonconsensual Cesareans will lead to other intrusions into pregnant wornen's lives. The Cesarean cases theinselves do not always involve surgery alone. For

373. In EFM cases, there will seldom be time for much more than a hasty phone call to a judge. See supra text accompanying notes 323-71, where judge contacted by telephone indicated that if necessary he would order surgery. Cases involving other indications for surgical delivery may afford the luxury of a few days or occasionally even weeks.

374. Even when counsel is appointed for the woman, there is often little or no time for case preparation. In Jefferson, for example, Mrs. Jefferson's counsel was appointed at 11:00 a.m. on Jan. 23, 1981, and the case was argued at 12:00 noon that same day. Letter from Hugh Glidewell (July 24, 1981) (on file with author). In the Headley case, North Central Bronx Hospital was represented by Bower \& Gardner, a firm specializing in health law, while the woman was not represented at all. Telephone interview with Nancy Gold, of Bower \& Gardner. (Jan. 13, 1986); see also Hubbard, supra note 5 , at 214-15 n.60 (cases almost inevitably infected with a disturbing procedural informality).

375. See supra text accompanying notes $369-71$, describing conflict in which the judge indicated he would order a Cesarean, but woman delivered vaginally before any order could be issued.

376. Even having obstetrical patient advocates in-house would not allow much time for challenging the medical findings, locating alternative experts, etc., and would of course be yery cumbersome and likely to evoke hostility from the medical staff. 
example, the chief of obstetrics at North Central Bronx Hospital was made guardian ad litem for Mrs. Headley and her fetus, with authority to consent to whatever diaguostic and therapeutic procedures were necessary for the fetus's liealth. ${ }^{377}$ The police were sent to locate Mrs. Jeffries and bring ler forcibly to the hospital. ${ }^{378}$ If a high-risk woman cannot refuse a Cesarean, it is hard to see how she can refuse the diagnostic procedures that will determine if a Cesarean is necessary. As doctors define "high risk" to include more and more women, ${ }^{379}$ freedom for any woman to opt out of this country's technologically intensive obstetrics may be threatened.

As we learn more about fetal development and the impact of maternal conduct on the fetus, diagnostic procedures and restrictions on women's conduct could be ordered earlier in preguancy. Already, some courts have ordered transfusions for pregnant Jellovah's Witnesses, ${ }^{380}$ and one court has done so even before the fetus was viable. ${ }^{381}$ At least one court has mvoluntarily committed a sclizophrenic woman in the last trimester of pregnancy in order to protect the fetus; ${ }^{382}$ anotler has ordered a pregnant heroin addict to report for drug testing; ${ }^{383}$ and yet anotlier has required a pregnant diabetic to take insulin despite her reli-

377. See North Cent. Bronx Hosp. v. Headley, No. 1992-85, slip op. at 6 (N.Y. Sup. Ct. Jan. 6, 1986).

378. See In re Baby Jeffries, No. 14004, slip op. at 9 (Jackson County, Mich. P. Ct. May 24, 1982) (authorizing police to return Mrs. Jeffries to the hospital). Contrast this with the North Central Bronx case, where the hospital sought authority to intervene only if Mrs. Headley voluntarily returned to the institution. North Cent. Bronx Hosp., No. 1992-85, slip op. at 1 (N.Y. Sup. Ct. Jan. 6, 1986).

379. One expert has stated, only in part facetiously, that the classification "low-risk" might best be made "by exclusion, three months after birth." Statement of Barry Schifrin, "Legal Implications of EFM," paper given at conference on Medicolegal Issues in Obstetrics in New York (Oct. 3, 1985).

380. Raleigh Fitkin-Paul Morgan Memorial Hosp. v. Anderson, 42 N.J. 421, 201 A.2d 537 (1964), cert. denied, 377 U.S. 985 (1964). This case was, of course, decided long before Roe v. Wade, which undermines its precedential value.

381. In re Jamaica Hospital, N.Y.L.J., May 17, 1985, at 15 (Queens Cty., Sup. Ct., Special Term, Part 2) (fetus was 18 weeks in gestation). This seems a logical extension if the mother is not going to abort. Whatever validity viability may have in the abortion context as a cut-off, if a fetus at great risk is definitely intended to be born, and the state has embarked upon compulsory intervention to protect imperiled fetuses, there seems little rcason to limit the state's power to protecting viable fetuses, especially since by then the harm may have already been done. See Robertson, supra note 7, at 361; see also Shaw, supra note 86 , at 83 (failure to make early abortion decision should not relieve pregnant woman of prenatal duties early in pregnancy). This is not to say that $I$ believe the state should start down this path-I obviously do not-but that once it does, temporal lines are very hard to justify.

382. Soloff, Jewell \& Roth, Civil Commitment and the Rights of the Unborn, 136 AM. J. PsyChiatry 114, 114 (1979). A California trial court civilly committed a woman in the last months of pregnancy to protect her fetus. Although the appellate court subsequently indicated its disapproval, by the time of the appeal, the case was moot. In re Steven S., 126 Cal. App. 3d 23, 31, 178 Cal. Rptr. 525, 527 (1981).

383. See Fletcher, supra note 5, at 34. 
gious beliefs. ${ }^{384} \mathrm{~A}$ criminal prosecution was brought against a California woman for the death of her infant son, who was born with brain damage allegedly resulting from her failure to seek immediate medical attention when she began to hemorrhage from placenta previa, though the action was dismissed. ${ }^{385}$ Interventions such as brief involuntary hospitalization, testing, or surveillance to control drinking, drug use, diet, etc., may be viewed by some courts as less intrusive than major surgery-though longer lasting, such interventions are, after all, much less risky. ${ }^{386}$ Visions of a "shippery slope" progression appear very real when one begins with mandatory major surgery.

The potential for far-reaching state control of pregnant women also is suggested by the frighterning array of prenatal interventions that some proponents of fetal protection advocate. For example, John Robertson states that pregnant woinen

may also be prohibited from using alcohol or other substances harmful to the fetus during pregnancy, or be kept from the workplace because of toxic effects on the fetus. They could be ordered to take drugs, such as insulin for diabetes, medications for fetal deficiencies, or intrauterine blood transfusions for $\mathrm{Rh}$ factor. Pregnant anorexic teenagers could be force fed. Prenatal screening and diagnostic procedures, from amniocentesis to sonography or even fetoscopy could be made mandatory. And, in utero surgery for the fetus to shunt cerebroventricular fluids from the brain to reheve hydrocephalus, or to to relieve the urethral obstruction of bilateral hydronephrosis could also be ordered. Indeed, even extra-uterine fetal surgery, if it becomes an established procedure, could be ordered, if the risks to the mother were small and it were a last resort to save the life or prevent severe disability in a viable fetus. ${ }^{387}$

Margery Shaw goes even further, approving of breathalyzer tests for pregnant women suspected of alcohol abuse, and seeming to countenance mandatory prenatal diagnosis and even abortion in cases of fetal defects so severe that abortion may be deemed in the fetus's best interest. ${ }^{388}$

384. In re Unborn Baby Wilson, No. 81-108 AV (Mich. Ct. App. Mar. 9, 1981). Hospital personnel are increasingly contemplating a number of potentially involuntary treatments. I have participated in ethics rounds at several hospitals in which the issue was whether a pregnant patient whose conduct was in some way harmful to the fetus could be forcibly hospitalized and treated.

385. People v. Stewart, No. M508197 (San Diego Mun. Ct. Feb. 26, 1987).

386. An interesting case concerning potential prenatal interventions is People v. Pointer, 151 Cal. App. 3d 1128, 199 Cal. Rptr. 357 (1984), in which a mother had been convicted of child endangerment for keeping her two young children on a macrobiotic diet that caused growth retardation and permanent neurological damage in the younger child. Id. at 1133, $199 \mathrm{Cal}$. Rptr. at 360. The trial judge had imposed, as a condition of probation, the requirement that Ms. Pointer refrain from conception. Id. at 1136,199 Cal. Rptr. at 362. The appellate court found this condition too restrictive of Ms. Pointer's rights, but explicitly approved less onerous conditions such as intensive monitoring of her diet if she became pregnant. Id. at 1140, $199 \mathrm{Cal}$. Rptr. at 365 .

387. Robertson, supra note 7, at 358-59; see also Myers, supra note 7, at 72-75.

388. Shaw, supra note 86 , at 74,87 . 
The civil liberties implications of all this are staggering, as are the equal protection problems, since pregnant women are the only candidates for this unprecedented state control. A more subtle problem is the potential for prenatal coercion to do fetuses as much liarm as good. In the North Central Bronx case, Mrs. Headley never returned to the hospital and, despite the risk, liad a home birth. ${ }^{389}$ Mrs. Jeffries went into hiding, and the pohice search for her was unsuccessful. ${ }^{390}$ Women of strong religious beliefs may forego care entirely rather than violate their principles, a course tliat puts the women and their babies at even greater risk. Pregnant women who take illicit drugs or engage in other types of conduct that may cause fetal liarm may avoid prenatal care for fear of involuntary lospitalization or treatment. ${ }^{391}$ Thus, ironically, efforts at fetal protection may instead increase fetal peril. Moreover, the coercion necessary to prevent "maternal flight"-surveillance, reporting requirements (as with child neglect), or sendimg out the "obstetrics police"-lias mind-boggling imphications for individual riglits in this country.

A final point is that altlough coercion to protect a fetus may seem tempting in the individual case when the fetus is imperiled, on a societal scale this is an extraordinarily inefficient way to reduce perinatal mortality and morbidity. In this country, many women are still unable to obtain any, or adequate, prenatal care ${ }^{392}$ even thougl good nutrition and basic care can vastly improve the outcome in many pregnancies. ${ }^{393}$ The societal tendency to take all measures possible to rescue an identified individual, while foregoimg precautions that could prevent many more deatlss (though to umdentifiable persons) ${ }^{394}$ is perhaps understandable.

389. Schulman interview, supra note 30. The North Central Bronx case is particularly disturbing in that Mrs. Headley, who very much wanted her baby, had intentionally chosen North Central Bronx because it has the least interventionist approach of all public hospitals in the New York area. She had come for prenatal care there, even though she lived quite far away-in Greenwich Village in Manhattan - and had established an excellent relationship with the midwife there who cared for her. Id.

390. Detroit Free Press, June 13, 1982 at 3A, col. 5; id. June 16, 1982 at 3A, col. 5.

391. See M. Poland, Influence of Reproductive Technology on Prenatal Responsibility 18 (Dec. 14-15, 1984) (unpublished paper presented at Planned Parenthood Association of America Symposium on Human Fertility Regulation, New York) (pregnant substance abuser's contacts with health professionals may be less than supportive, and she may wish to avoid what she views as a punitive attitude).

392. See Rosenbaum, supra note 302, at 703-04 (summarizing how unemployment and cutbacks in Medicaid and other programs have deprived more women of access to prenatal care); see also Hubbard, supra note 5, at 217-18 (noting program cutbacks and irony of mandating "high tech" treatment while failing to provide basic care for many).

393. Low birthweight is the leading cause of neonatal death. Rosenbaum, supra notc 302, at 702. This problem is exceedingly responsive to basic prenatal care. Id. at 703. According to Rosenbaum, the federal government has estimated that every dollar spent on prenatal care yields four dollars in savings from reduced hospital and long-term institutional care for handicapped infants. Id. at 710 .

394. See Murray, supra note 263 , at $47-50$ (discussing disparity between this country's emphasis on rescue and deemphasis on prevention). 
But in this area, it is irrational to fail to provide prenatal care to all, thus risking many mothers and babies, and at the same time make women with atypical rehigious or inedical behefs choose between accepting care that violates their most cherished behiefs and foregoing care altogether. How much wiser it would be instead to ensure that caregivers work with these woinen to provide the best medical care possible within the himitations of their behef systems. ${ }^{395}$

\section{CONCLUSION}

We must not deny that conflicts in the birthing process are extraordinarily difficult. Feelings of helplessness and doom pervade the delivery room as a natural birth unnecessarily becomes a natural disaster. Absent intervention, an infant may die or suffer life-long misery simply because his inother refused surgery. With these stakes, it is no wonder that doctors often are willing not only to persuade but, with the court's permission, to coerce. It is very teinpting in the individual case for a judge to "coine down on the side of life." But as we have seen, the judge who orders surgery does so at a far higher cost than it initially appears. $\mathrm{He}$ forces burdens on the woinan that no one else in society must ever bear. He inposes risks on lier that are imposed on no one else. And lie coinproimses the state's integrity by acting coercively, albeit for a good cause.

Moreover, medical authority does not guarantee medical omniscience. Given technological limitations, prevailing obstetrical practices, and the inpact of the looming threat of malpractice liability, doctors' fears may be inflated and their motives mixed. In soine cases, there may be much to say against the doctor's recommendations and predictions. But it will not get said. Judges will never hear from the woman who has crept back home to dehiver safely, or unsafely, there. Nor are they likely to hear lucid constitutional arguments from the one in the hospital, in the sweaty agomies of labor, or from her counsel, appointed one hour before the hearing. If informed consent in obstetrics is gradually replaced by enforced acquiescence, this transformation will most likely occur without there ever being a truly two-sided, fully litigated liearing.

In any individual case, the immediacy of the potentially tragic consequences will be enormously compelhing. It will be extremely hard for judges to refrain from overriding refusals in order to prevent these consequences. But on a broader societal scale, preventing these tragedies coines at the cost of embracing an unprecedented and problematic tyr-

395. It would, of course, be appropriate to specify that the physician is not liable for any injuries caused by the woman's refusal of recommended treatment. This is how some institutions deal with the problem of operating on competent adult Jehovah's Witnesses without using blood. They have certain physicians who are willing to run this risk and they thoroughly document that the patient refuses blood and that the doctor is not responsible for death or injury stemming from such refusal. 
anny of medicine and technology, and a tyranny whose potential scope knows no bounds. I, for one, believe it is better for our society to choose the occasional tragedy and for judges to stay out of the delivery room. 